\title{
Synthesis and properties of iso-bicyclo DNA
}

\author{
Anna-Barbara Gerber and Christian J. Leumann**a]
}

\begin{abstract}
We present the synthesis of the iso-bicyclo DNA building blocks with the nucleobases A, C, G and T, as well as biophysical and biological properties of oligonucleotides derived thereof. The synthesis of the sugar part was achieved in 5 steps starting from a known intermediate of the tricycloDNA synthesis. Dodecamers containing single iso-bicyclo thymidine incorporations, fully modified A- and T-containing sequences and fully
\end{abstract}

modified oligonucleotides containing all four bases were synthesized and characterized. Iso-bicyclo DNA forms stable duplexes with natural nucleic acids with a pronounced preference for DNA over RNA as complements. The most stable duplexes, however, arise by self-pairing. Iso-bicyclo DNA forms preferentially B-DNA-like duplexes with DNA and A-like duplexes with complementary RNA as determined by CD-spectroscopy. Self-paired duplexes show a yet unknown structure, as judged from CD-spectroscopy. Biochemical tests revealed that isobicyclo DNA is stable in fetal bovine serum and does not elicit RNase $\mathrm{H}$ activity.

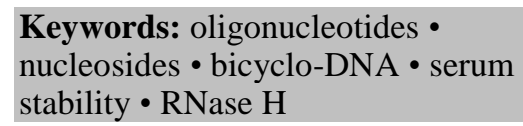

\section{Introduction}

Oligonucleotides are a class of compounds with considerable therapeutic potential. Unlike small molecule drugs that typically target proteins, therapeutic oligonucleotides act via Watson-Crick hybridization to a matched sequence tract on an RNA of interest, modulating its biological function. ${ }^{[1]}$ Originally, mRNAs of disease related proteins have been the target of classical antisense oligonucleotides that either sterically block or induce RNase $\mathrm{H}$ degradation of the mRNA in vivo. ${ }^{[2]}$ The project ENCODE, ${ }^{[3]}$ recently revealed that $80 \%$ of the human genome is transcribed into RNA. Of these RNAs only $2 \%$ encode for proteins while a considerable subset, such as micro-RNAs (miRNAs) and generally non-coding RNAs, is involved in gene regulation. Thus, they play a pivotal role in the onset of disease which greatly expands the palette of RNA sequences as therapeutic targets in the future.

Basic requirements for therapeutic oligonucleotides are i) high affinity towards a target RNA, ii) biostability, and iii) cellular availability. A large number of chemical modifications on the DNA bases, sugar and internucleoside linkage have been reported over the last two decades, but only a handful of those have been used in extensive pre-clinical or clinical tests. Amongst those are the class

[a] Dr. A.-B. Gerber, Prof. C. J. Leumann

Department of Chemistry \& Biochemistry

University of Bern

Freiestrasse 3, 3012 Bern (Switzerland)

Fax: (+41)31-631-3422

E-mail: leumann@ioc.unibe.ch of 2'O-alkylated RNA, ${ }^{[4]}$ the morpholino phosphorodiamidates, ${ }^{[5]}$ the peptide nucleic acids (PNA) ${ }^{[6]}$ and the locked nucleic acids $(\mathrm{LNA})^{[7]}$.

In our laboratory we have been involved in the design and synthesis of conformationally constrained oligonucleotides over the last two decades. Offsprings of these efforts were the bicyclo- ${ }^{[8]}$ and tricycloDNA $^{[9]}$ molecular platform (Figure 1). Unique to both families is the carbocyclic 5-membered ring connecting $\mathrm{C}\left(5^{\prime}\right)$ and $\mathrm{C}\left(3^{\prime}\right)$ and thereby rigidifying the rotational freedom around the $\mathrm{C}\left(3^{\prime}\right)-\mathrm{C}\left(4^{\prime}\right)$ and the $\mathrm{C}\left(4^{\prime}\right)-\mathrm{C}\left(5^{\prime}\right)$ bonds (Figure 1, A and C).

Besides conformational restriction this carbocyclic ring offers the unique advantage to change the geometry of the repeating backbone unit in a single strand by moving the hydroxyl groups involved in the internucleotidic linkages to other $\mathrm{C}$-atoms within the cycle. In this context we became interested in exploring the properties of isobicyclo-DNA (Figure $1 \mathrm{~B}$ ) in which the the $\mathrm{C}\left(5^{\prime}\right.$ ) hydroxyl group has been moved to $\mathrm{C}\left(6^{\prime}\right)$. Interestingly, this iso-bicyclo-DNA shows the same number of bonds within the repeating backbone unit as DNA. In this article we report on the synthesis of the corresponding iso-bicyclo-DNA building blocks with all four natural bases, on their incorporation into oligonucleotides, their RNA and DNA recognition properties, as well as on their structure as determined by $\mathrm{CD}$-spectroscopy and their biological properties (serum stability and RNaseH activation).
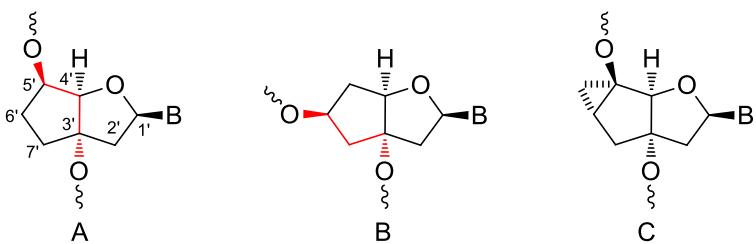

Figure 1. A: bicyclo DNA, B: iso-bicyclo DNA, C: tricyclo DNA 


\section{Results}

Molecular modeling of monomers: To investigate the influence of the $\mathrm{C}\left(5^{\prime}\right) \rightarrow \mathrm{C}\left(6^{\prime}\right)$ hydroxyl shift on the structure of the nucleosides a conformational search was performed using the $\mathrm{MM}+$ force field as implemented in the software package HyperChem ${ }^{\mathrm{TM}}$. The $\mathrm{C}\left(3^{\prime}\right)$, $\mathrm{C}\left(5^{\prime}\right)$ dimethylated iso-bicylo thymidine was initially built in a $2^{\prime}$ endo conformation and then energy minimized. In a conformational search experiment all endocyclic torsion angles were then varied, resulting in two different low energy conformational families (Figure 2). Table 1 summarizes the endocyclic torsion angles of the furanose unit and the corresponding energies of two representative structures of each family. The lowest energy conformer turned out to be that with the 6' substituent in an axial position (Figure 2a). This structure fits well into a B-DNA double helix as judged from simple model building.

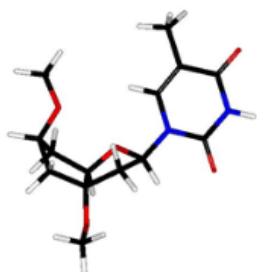

a)

Figure 2. Lowest energy conformers of 3',5'-dimethylated iso-bicyclo-thymidine:: a) $\mathrm{O}\left(6^{\prime}\right)$ in axial position, furanose in $\left.\mathrm{C}^{\prime} 1^{\prime}\right)$-exo conformation;. b) $\mathrm{O}\left(6^{\prime}\right)$ in equatorial position, furanose in $\left.\mathrm{C}^{(} 4^{\prime}\right)$-exo conformation.

Table 1. Results of the conformational search experiment for an iso-bicyclic thymidine. $\omega$ is the angle between the phosphate oxygen and the C6'

\begin{tabular}{lllllllll}
\hline & $v 0$ & $v 1$ & $v 2$ & $v 3$ & $v 4$ & $\omega$ & $\begin{array}{l}\text { Furanose } \\
\text { pucker }\end{array}$ & $\begin{array}{l}\text { Energy } \\
{[\mathrm{kcal} / \mathrm{mol}]}\end{array}$ \\
\hline a) & $-41^{\circ}$ & $35^{\circ}$ & $-17^{\circ}$ & $-6^{\circ}$ & $30^{\circ}$ & $82^{\circ}$ & $\mathrm{C}\left(1^{\prime}\right)$-exo & 29.22 \\
b) & $-36^{\circ}$ & $15^{\circ}$ & $8^{\circ}$ & $-30^{\circ}$ & $41^{\circ}$ & $170^{\circ}$ & $\mathrm{C}\left(4^{\prime}\right)$-exo & 30.26 \\
\hline
\end{tabular}

Synthesis of the iso-bicyclo sugar: The bicyclic silyl enolethers 1a (C(1') alpha), 1b $\left(\mathrm{C}\left(1^{\prime}\right)\right.$ beta) used in the synthesis of the tricyclo sugar ${ }^{[10]}$ were considered to be the starting materials of choice for the synthesis of the iso-bicyclo DNA scaffold. Hydroboration of $\mathbf{1 a}$ or $\mathbf{1 b}$ yielded the compounds $\mathbf{2 a}, \mathbf{2 b}$ and $\mathbf{3 a}, \mathbf{3 b}$ (Scheme 1) in diastereomeric ratios of $4: 1$ in the $\alpha$-series and 10:1 in the $\beta$-series. ${ }^{[11]}$ The lowest abundant isomer $\mathbf{3 b}$ could not be isolated as a pure compound and was not used in further transformations. All other isomers $\mathbf{2 a}, \mathbf{2} \mathbf{b}$ and 3a were taken forward in the following nucleoside synthesis. Acetylation of $\mathbf{2 a}, \mathbf{2 b}$ and 3a was performed under standard conditions using $\mathrm{Ac}_{2} \mathrm{O} / \mathrm{DMAP}$ in pyridine at room temperature yielding $\mathbf{4 a}, \mathbf{4 b}$ and $\mathbf{5 a}$. Desilylation with $\mathrm{HF} / \mathrm{Et}_{3} \mathrm{~N}(37 \% \mathrm{HF})$ in $\mathrm{THF}$ yielded compounds $\mathbf{6 a}, \mathbf{6 b}$ and $7 \mathbf{a}$. To defunctionalize $\mathrm{C}\left(5^{\prime}\right)$, the alcohols $\mathbf{6 a}, \mathbf{6} \mathbf{b}$ and $7 \mathbf{a}$ were converted into the thiocarbamates $\mathbf{8 a}$, 8b and 9a in good yields. The subsequent Barton McCombie reduction was performed with AIBN as the radical initiator and tris(trimethylsilyl)silane (TTMSS) as the H-donor to yield 10a, 10b and 11a, again in good yields (Scheme 1).

Synthesis of the phosphoramidite building blocks: The nucleosidation of building block 10b (for nucleosidation of 10a see supporting information) with the bases $\mathrm{T}, \mathrm{A}^{\mathrm{Bz}}$ and $\mathrm{C}^{\mathrm{Bz}}$ was performed under Vorbrüggen conditions leading to close to $1: 1$ mixtures of anomers $12 \mathrm{a} / \mathbf{b}, \mathbf{1 3 a} / \mathbf{b}$ and $\mathbf{1 4 a} / \mathbf{b}$ in $75-85 \%$ yields that were not separable by standard chromatography techniques (Scheme 2). Subsequent deacetylation under mild conditions yielded $\mathbf{1 5} \mathbf{a} / \mathbf{b}$, $\mathbf{1 6} \mathbf{a} / \mathbf{b}$ and $\mathbf{1 7 a} / \mathbf{b}$. We decided to invert the configuration at $\mathrm{C}\left(6^{\circ}\right)$ at this stage. Therefore the free nucleosides $15 \mathbf{a} / \mathbf{b}, \mathbf{1 6} \mathbf{a} / \mathbf{b}$ and $17 \mathbf{a} / \mathbf{b}$ were converted into the corresponding $\mathrm{C}\left(6^{\prime}\right)$ mesylates $\mathbf{2 1 a} / \mathbf{b}, \mathbf{2 2 a}$, $\mathbf{2 2 b}$ and $\mathbf{2 3 a} / \mathbf{b}$. At this point it was possible to separate the $\alpha$ - and $\beta$ anomers of $\mathbf{2 2}$ by column chromatography, while $\mathbf{2 1}$ and $\mathbf{2 3}$ had unfortunately still to be taken forward as mixtures of anomers. Subsequent acetylation of $\mathrm{O}\left(3^{\prime}\right)$ followed by displacement of the 6'mesyl function by CsOAc in DMSO yielded $\mathbf{2 4 a} / \mathbf{b}, \mathbf{2 5} \mathbf{b}$ and $\mathbf{2 6} \mathbf{a} / \mathbf{b}$. Saponification $(\rightarrow \mathbf{2 7} \mathbf{a} / \mathbf{b}, \mathbf{2 8 b}, \mathbf{2 9} \mathbf{a} / \mathbf{b})$ and subsequent tritylation gave compounds 30a, 30b, 31b, 32a, 32b. As already observed in other cases the tritylated nucleosides $\mathbf{3 0}$ and $\mathbf{3 2}$ were now separable by chromatography and isolated as pure isomers. The relative configuration at the centers $\mathrm{C}\left(1^{\prime}\right)$ in $\mathbf{3 0 b}, \mathbf{3 1 b}$ and $\mathbf{3 2 b}$ was ascertained by ${ }^{1} \mathrm{H}-\mathrm{NMR}$-ROESY (supplementary information). The treatment of the beta-nucleosides 30b, 31b and 32b with CEP-Cl under standard conditions finally yielded the desired phosphoramidites 33b, 34b and 35b.

For the synthesis of the iso-bicyclo guanosine, a slightly different protecting group strategy had to be employed due to the notoriously high degree of insolubility imparted by the guanine base. Thus the $\mathrm{O}\left(3^{\prime}\right)$ and $\mathrm{O}\left(5^{\prime}\right)$ acetyl groups in $\mathbf{1 0 b}$ were replaced by TBS groups, leading to $\mathbf{3 7 b}$ that was subjected to nucleosidation with 2-amino-6-chloropurine under classical Vorbrüggen conditions giving nucleosides $\mathbf{3 8} \mathbf{a} / \mathbf{b}$ in an anomeric ratio of $1: 1$ in acceptable yields (Scheme 3). Treatment of $\mathbf{3 8} \mathbf{a} / \mathbf{b}$ with sodium hydride and 3 hydroxypropionitrile exchanged the $\mathrm{C}\left(6^{\prime}\right)$-chloro substituent by oxygen $(\rightarrow 39 \mathbf{a} / \mathbf{b})$. Further protection of the exo amino function of

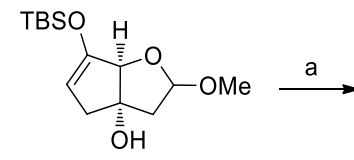<smiles>[R2]C1C[C@]2([R2])C[C@H](OC)O[C@@H]2[C@H]1[R]</smiles>

$$
\begin{gathered}
\text { 1a or } 1 \mathbf{b} \\
\text { 1a: } \longrightarrow 2 \mathrm{2a}: 3 \mathrm{a}=4: 1 \\
1 \mathrm{~b}: \longrightarrow 2 \mathrm{~b}: 3 \mathbf{b}=10: 1
\end{gathered}
$$

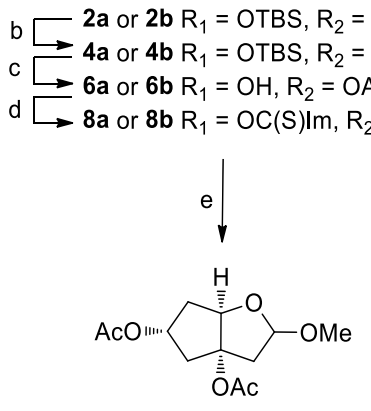

$10 \mathrm{a}$ or $10 \mathrm{~b}$
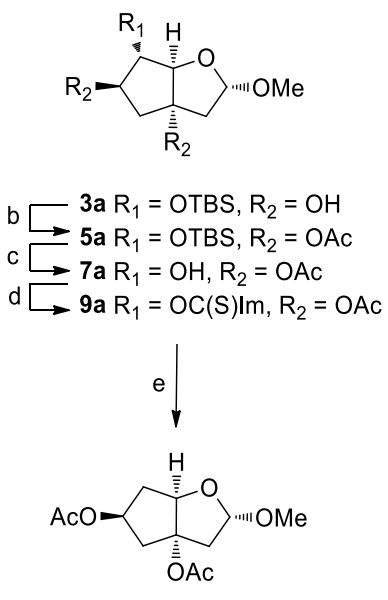

$11 \mathrm{a}$
Scheme 1. a) $1 . \mathrm{BH}_{3}$.THF, THF, $-78^{\circ} \mathrm{C} \rightarrow$ r.t., $22 \mathrm{~h}, 2$. Oxone in sat. $\mathrm{NaHCO}_{3}$, r.t., 2 h, $80 \%$ b) $\mathrm{Ac}_{2} \mathrm{O}$, DMAP, pyridine, r.t., $95 \%$ c) $\mathrm{HF}_{2} \mathrm{Et}_{3} \mathrm{~N}, \mathrm{THF}$, r.t. $85 \%$ d) TCDI, THF, reflux, $82 \%$ e) AIBN, TTMSS, toluene, reflux, $82 \%$

the guanine base yielded amidine $\mathbf{4 0 a} / \mathbf{b}$. In order to invert the configuration at $\mathrm{C}\left(6^{\prime}\right)$, selective desilylation at this position was 


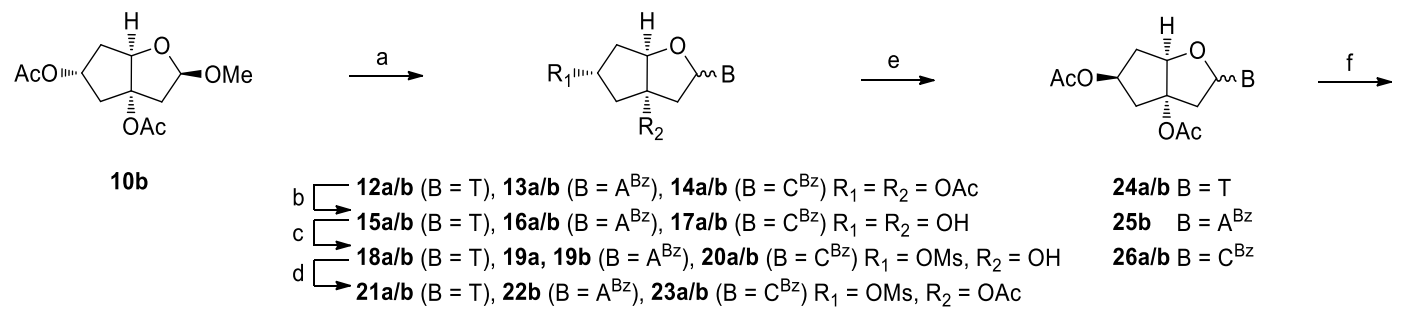<smiles>OC1CC2CC3CCC3OC2C1</smiles>
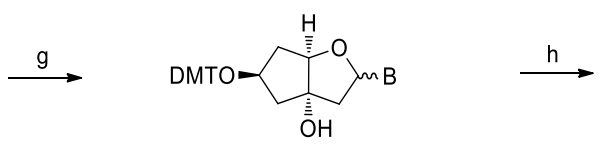

$27 \mathbf{a} / \mathbf{b} B=T$
$28 b \quad B=A^{B z}$
$29 a / b \quad B=C^{B z}$

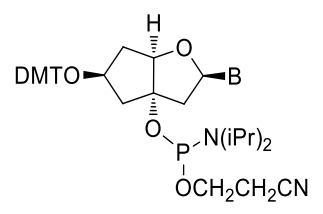

$33 b \mathrm{~B}=\mathrm{T}$

$34 b B=A^{B z}$

$35 \mathrm{~b} B=C^{B Z}$

Scheme 2. a) Thymine (2eq.), BSA (5eq.), TMSOTf (3eq.), MeCN, $0^{\circ} \mathrm{C}$ - rt, $85 \%$ / Benzoyl-adenine (2eq.), BSA (4eq.), TMSOTf (0.3eq.), $\mathrm{MeCN}, 85^{\circ} \mathrm{C}, 75 \%$ / Benzoyl-cytosine (2eq.), BSA (5eq.), TMSOTf (3eq.), $0^{\circ} \mathrm{C}-\mathrm{rt}, 75 \%$ b) $0.2 \mathrm{M} \mathrm{NaOH}$ in 5:4:1 $\mathrm{THF} / \mathrm{MeOH} \mathrm{H}_{2} \mathrm{O}, 0^{\circ} \mathrm{C}, 75-$ $90 \%$ c) $\mathrm{MsCl}$ ( 1 eq.), Pyridine, $0^{\circ} \mathrm{C} \rightarrow$ r.t., $60-70 \%$ d) $\mathrm{Ac}_{2} \mathrm{O}$, DMAP, pyridine, r.t, 80-91\% e) $\mathrm{CsOAc}$, DMSO, $90^{\circ} \mathrm{C}, 81-93 \%$ f) $0.2 \mathrm{M} \mathrm{NaOH}$ in 5:4:1 THF/MeOH, $\mathrm{H}_{2} \mathrm{O}, 0^{\circ} \mathrm{C}, 60-84 \%$ g) DMT-Cl, Pyridine, r.t., 48\% (30a), 40\% (30b), 90\% (31b), 62\% (32a), 30\% (32b) h) Hünig's Base, $\mathrm{CEP}-\mathrm{Cl}, \mathrm{MeCN}$, r.t., $72-87 \%$

desirable. This goal was achieved by the use of $\mathrm{HF} / \mathrm{Et}_{3} \mathrm{~N}(\rightarrow \mathbf{4 1 a} / \mathbf{b})$. Despite desilylation with fluoride ions is known to be unspecific ${ }^{[12]}$ we observed high selectivity towards deprotection of the sterically less hindered $\mathrm{O}\left(6^{\prime}\right)$. The free hydroxyl group in $\mathbf{4 1} \mathbf{a} / \mathbf{b}$ was then mesylated $(\rightarrow \mathbf{4 2} \mathbf{a} / \mathbf{b})$, inverted $(\rightarrow \mathbf{4 3 a} / \mathbf{b})$ and the acetyl function removed with concomitant removal of the amidine protecting group, leading to the chromatographically separable anomers $\mathbf{4 4 a}$ and $\mathbf{4 4 b}$. Reprotection of the $\mathrm{N}(2)$ amino function in the $\beta$-anomer $(\rightarrow \mathbf{4 5 b})$ and DMT protection using standard conditions yielded $46 \mathrm{~b}$ in good yields. Subsequent deprotection with TBAF $(\rightarrow \mathbf{4 7 b})$ followed by phosphitylation finally concluded the synthesis of the iso-bicyclo-G building block 48b. Again, the relative configuration at $\mathrm{C}\left(1^{\prime}\right)$ was confirmed by ${ }^{1} \mathrm{H}-\mathrm{NMR}-\mathrm{ROESY}$ on compound $\mathbf{4 7 b}$ (supplementary information).

with complementary DNA and RNA do not deviate significantly in shape from that of S5, indicating minor structural perturbations imparted by the iso-bc-T residues (Figure S5 and S6, supporting information).

Table 2. $\mathrm{T}_{\mathrm{m}}$ values derived from UV-melting-temperature experiments at $260 \mathrm{~nm}$ Conditions: $10 \mathrm{mM} \mathrm{NaH} \mathrm{PO}_{4}, 150 \mathrm{mM} \mathrm{NaCl}, \mathrm{pH} 7.0, \mathrm{c}=1.2 \mu \mathrm{M}$ strand concentration.

\begin{tabular}{llll}
\hline & Sequence $^{[\mathrm{a}]}$ & Complementary DNA & Complementary RNA \\
\hline S1 & 5'-d(GGAtGTTCTCGA)-3' & 48.0 & 49.0 \\
S2 & 5'-d(GGATGttCTCGA)-3' & 49.0 & 47.5 \\
S3 & 5'-d(GGATGTTCtCGA)-3' & 48.0 & 50.0 \\
S4 & 5'-d(GGAtGttCtCGA)-3' & 51.0 & 49.5 \\
S5 & 5'-d(GGATGTTCTCGA)-3' & 47.0 & 49.0 \\
\hline
\end{tabular}

Oligonucleotide synthesis: Modified oligonucleotides were synthesized using standard phosphoramidite chemistry on a DNA synthesizer on the $1.3 \mu \mathrm{mol}$ scale. Either natural deoxynucleoside derived $\mathrm{CPG}$ solid support or, for the fully modified strands, a universal solid support was used. For the incorporation of the isobicyclo nucleoside building blocks the coupling time was increased to $9 \mathrm{~min}$. All other steps remained unchanged. After chain assembly the oligonucleotides were cleaved from the solid support and deprotected by aminolysis at $70^{\circ} \mathrm{C}$ over night, then purified by reverse phase or ion exchange HPLC. The expected masses were confirmed by $\mathrm{ESI}^{-}$mass spectrometry.

Biophysical properties of oligo nucleotides containing iso-bicyclo thymidines: Oligonucleotides S1-S4 containing single and consecutive iso-

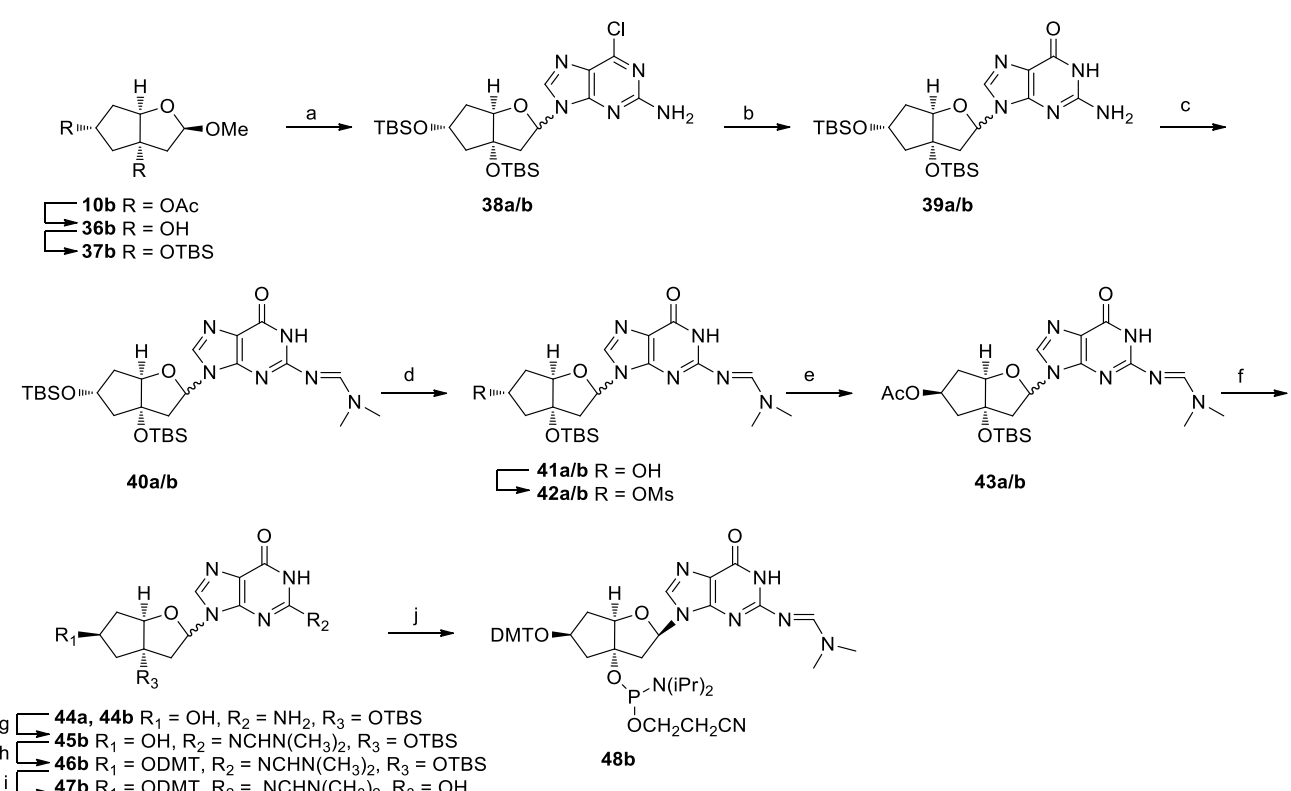

Scheme 3. a) 2-amino-6-chloropurine, BSA, TMSOTf, $\mathrm{MeCN}, 60^{\circ} \mathrm{C}, 5 \mathrm{~h}, 64 \%$ b) $\mathrm{NaH}, 3$-hydroxypropionitrile, THF, $0^{\circ} \mathrm{C}$-r.t. $3 \mathrm{~h}$ c) N,N-DMF-dimethylacetal, DMF, $55^{\circ} \mathrm{C}, 3 \mathrm{~h}, 71 \%$ over two steps d) $\mathrm{HF} / \mathrm{Et}_{3} \mathrm{~N}$, THF, r.t., $55 \%$ e) $\mathrm{MsCl}$, pyridine, r.t., $92 \%$ c) $\mathrm{CsOAc}$ DMSO, $85^{\circ} \mathrm{C}, 16 \mathrm{~h}, 85 \%$ f) $1 \mathrm{M} \mathrm{KOH}$ in $5 / 3 \mathrm{MeOH} / \mathrm{H}_{2} \mathrm{O}, 60^{\circ} \mathrm{C}, 42 \%$ (53b), $20 \%$ (53a) g) N,N- DMF-dimethylacetal, DMF, $55^{\circ} \mathrm{C}, 3$ h, 64\%h) DMT-Cl, pyridine, r.t., 16 h, 94\%i) TBAF, THF, r.t., 5h, 70\% j) Hünig's base, Cep-Cl, MeCN, r.t., 1h, 88\% 
Synthesis and properties of fully modified oligonucleotides containing iso-bc-T and iso-bc-A: As for the synthesis with single iso-bc-T incorporations, a non-self-complementary sequence motif was chosen. S6 and S7 (Table 3) are complementary and can therefore give insight into the self-pairing of iso-bicyclo DNA. The melting curves of S6 and S7 with complementary DNA and RNA partially confirm the results obtained with the thymidine modified oligonucleotides. All duplex melting curves reflect cooperative and reversible melting (Figure 3). The iso-bc modifications stabilize duplexes with DNA, but not as predicted from single incorporations with $1{ }^{\circ} \mathrm{C}$ per modification. The overall stabilization is $+2^{\circ} \mathrm{C}$ (S6) and $+3^{\circ} \mathrm{C}(\mathbf{S 7})$ per duplex, respectively (Table 3).

Table 3. $T_{\mathrm{m}}$ values derived from UV-melting-temperature experiments at $260 \mathrm{~nm}$ Conditions: $10 \mathrm{mM} \mathrm{NaH}_{2} \mathrm{PO}_{4}, 150 \mathrm{mM} \mathrm{NaCl}, \mathrm{pH} 7.0, \mathrm{c}=1.2 \mu \mathrm{M}$ strand concentration. [a] not measured

\begin{tabular}{lllll}
\hline & Sequence & $\begin{array}{l}\text { Tm vs DNA } \\
\text { antiparallel }\end{array}$ & $\begin{array}{l}\text { Tm vs RNA } \\
\text { antiparallel }\end{array}$ & $\begin{array}{l}\text { Tm vs DNA } \\
\text { parallel }\end{array}$ \\
\hline S6 & 6'-d(ataatttaataa)-3' & 25.1 & $<10$ & 21.9 \\
S7 & 6'-d(ttattaaattat)-3 & 25.9 & $<10$ & 28.1 \\
S8 & 5'-d( ATAATTTAATAA)-3 & 23.2 & n.m. ${ }^{\text {[a] }}$ & 19.8 \\
S9 & 5'-d(TTATTAAATTAT)-3' & 23.2 & 11.2 & n.m. ${ }^{\text {[a] }}$ \\
\hline
\end{tabular}

In the case of RNA as complement duplex destabilization with a $T_{\mathrm{m}}$ value below $10^{\circ} \mathrm{C}$ is observed. This was predicted from the earlier experiments where we have shown that single incorporations stabilize the duplex and consecutive modifications destabilize it Thermal denaturation experiments were also performed for the fully modified duplex S6:S7. The $T_{\mathrm{m}}$ in this case is remarkably high with

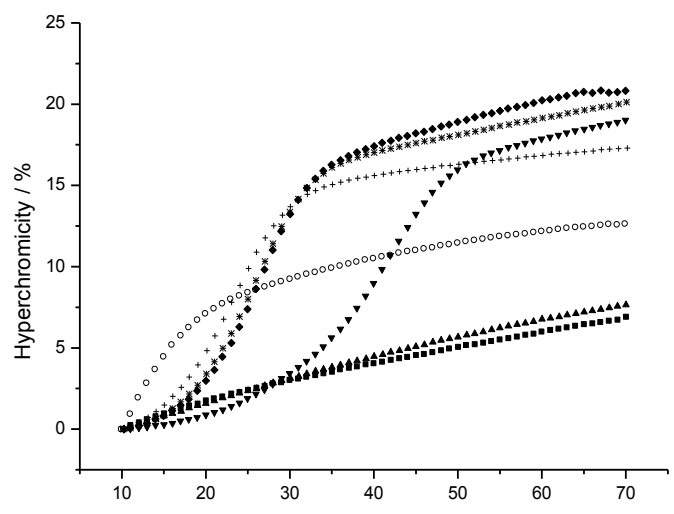

Figure 3. UV -melting curves $(260 \mathrm{~nm})$ of the AT-duplexes. Conditions: $10 \mathrm{mM}$ $\mathrm{NaH}_{2} \mathrm{PO}_{4}, 150 \mathrm{mM} \mathrm{NaCl}, \mathrm{pH} 7.0, \mathrm{c}=1.2 \mu \mathrm{M}$ strand concentration. - S6:RNA, $\Delta$ S7:RNA, $\nabla$ S6:S7, ○ DNA:RNA, + DNA:DNA, $*$ S6:DNA, $\bullet$ S7:DNA

a value of $41.9^{\circ} \mathrm{C}$ which is almost twice as high as that for the natural DNA duplex. Furthermore, to check the specificity for the antiparallel orientation in the duplex, melting temperatures for the parallel duplexes with DNA were measured (Figure S3, supporting information). Both, S6 and $\mathbf{S 7}$, showed $T_{\mathrm{m}}$ values that are comparable to the ones measured for the antiparallel duplexes $\left(-3^{\circ} \mathrm{C}\right.$ for $\mathbf{S 6}$ and $+2^{\circ} \mathbf{C}$ for $\mathbf{S 7}$, Table 3). The same is true for the natural duplex, which was slightly destabilized by $-3^{\circ} \mathrm{C}$ compared to the antiparallel duplex.

It thus appears that, much like natural DNA, ${ }^{[13]}$ also iso-bc-AT sequences have the potential to form parallel reverse Watson-Crick duplexes. It also becomes clear that iso-bc-AT-oligonucleotides do not have a considerable stabilizing effect on duplexes with DNA but have a significant destabilizing effect on duplexes with RNA as complement. In contrary, the fully unnatural duplex is significantly more stable compared to pure DNA or hybrid (iso-bicycloDNA/DNA) duplexes. This is not uncommon for sugar-modified oligonucleotide analogues, such as $\mathrm{HNA}^{[14]}$ or tc-DNA, and reflects most likely a more perfect geometric match of the repeating backbone units in homo-backbone duplexes as compared to heterobackbone duplexes.

In order to get insight into the structural properties of these AT duplexes, circular dichroism (CD) spectra were measured. The CD spectra for the natural duplex S8:S9 as well as for the hybrid duplex S6:S9 (Figures S7 and S8, supplementary information) showed a Blike conformation and, in the case of the fully modified duplex S6:S7 the CD spectrum showed a signature that is significantly different from A-, B, or Z-DNA (Figure 4). The CD traces of the single strands (at high temperature) are similar to the unmodified ones and the hybrid duplexes. In the paired state, however, the CD shows an intense negative band between 290 and $260 \mathrm{~nm}$, which mirrors the band of the unmodified duplex in this part of the spectrum (Figure 4). For the parallel duplexes in all three cases a Btype conformation is observed (Figure S9, supplementary information).

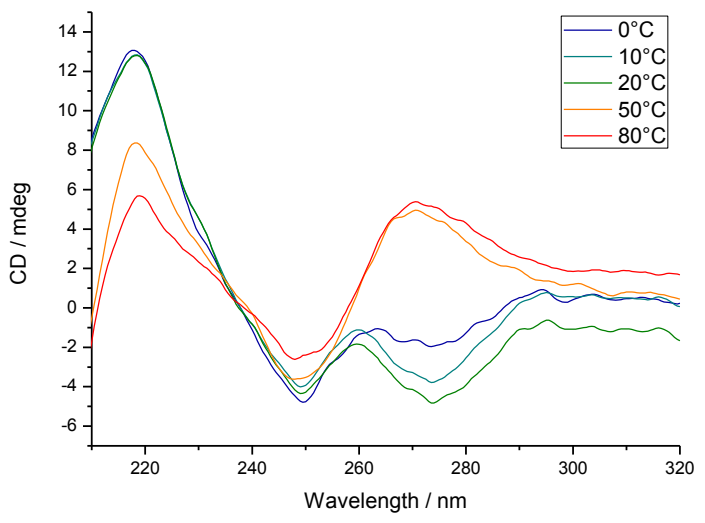

Figure 4. $\mathrm{CD}$ spectrum of the duplex S6:S7 at different temperatures. Conditions: 10 $\mathrm{mM} \mathrm{NaH} \mathrm{PO}_{4}, 150 \mathrm{mM} \mathrm{NaCl}, \mathrm{pH} 7, \mathrm{c}=1.2 \mu \mathrm{M}$ strand concentration.

Reported CD spectra of natural, parallel AT-duplexes were found to be sequence specific: A parallel duplex with alternating AT base pairs shows a negative band at $290 \mathrm{~nm}^{[15]}$ whereas a d(A) ${ }_{10} \cdot \mathrm{d}(\mathrm{T})_{10}$ hairpin shows a spectrum close to the one obtained in our case ${ }^{[13]}$. However, the negative band between 260 and $290 \mathrm{~nm}$ in the S6:S7 duplex is most likely not the result of a partial parallel iso-bc-AT duplex structure since achieving a melting temperature of $41.9^{\circ} \mathrm{C}$ with a minimum of 6 mismatches in a dodecamer seems very unlikely. Hence we hypothesize that there exists a different, yet undetermined duplex conformation for pure iso-bc-AT duplexes.

Thermodynamics of duplex formation: Using standard curve fitting procedures to experimental melting curves ${ }^{[16]}$ we calculated the thermodynamic data of duplex formation of the fully modified duplex S6:S7 as well as the hybrid duplex $\mathbf{S 6 : S 9}$ and compared the data to that of the natural duplex S8:S9 (Table 4). From there it appears that the natural duplex S8:S9 is enthalpically favored over the fully modified duplex. The free energy $\Delta \mathrm{G}^{25^{\circ} \mathrm{C}}$ is, as expected from the $T_{\mathrm{m}}$-data, in favor of the fully modified duplex S6:S7. Thus the fully modified duplex is entropically favored which is in agreement with its reduced conformational flexibility. The hybrid duplex shows a somewhat unusually high enthalpy $\Delta \mathrm{H}$, which is 
counterbalanced by the entropy term, indicating enthalpy/entropy compensation to be operative.

Table 4. Thermodynamic data of duplex formation from curve fitting to the experimental melting curve. Conditions: $10 \mathrm{mM} 10 \mathrm{mM} \mathrm{NaH} \mathrm{PO}_{4}, 150 \mathrm{mM} \mathrm{NaCl}, \mathrm{pH}$ $7.0, \mathrm{c}=1.2 \mu \mathrm{M}$ strand concentration

\begin{tabular}{llll}
\hline Duplex & $\Delta \mathrm{H}\left(\mathrm{kcal} \cdot \mathrm{mol}^{-1}\right)$ & $\left.\Delta \mathrm{S} \mathrm{cal} \cdot \mathrm{mol}^{-1} \cdot \mathrm{K}^{-1}\right)$ & $\Delta \mathrm{G}^{25^{\circ} \mathrm{C}}\left(\mathrm{kcal} \cdot \mathrm{mol}^{-1}\right)$ \\
\hline S6:S7 & -73.0 & -202.8 & -12.6 \\
S6:S9 & -84.7 & -254.0 & -8.9 \\
S8:S9 & -76.6 & -228.9 & -8.3 \\
\hline
\end{tabular}

We also investigated the influence of salt concentration on duplex stability by varying the $\mathrm{NaCl}$ concentration of the buffer in a range from $0.05 \mathrm{M}-1.5 \mathrm{M}$. The uptake of sodium ions upon duplex formation helps to stabilize the duplex by reducing the repulsion between the phosphate groups. Since the negative charge density is higher in a duplex than in single strands, counter ions are screened upon duplex formation. As expected, an increase of the $T_{\mathrm{m}}$ values with increasing $\mathrm{NaCl}$ concentration was observed (Figure 5). The duplexes S8:S9 and S6:S9 both doubled their $T_{\mathrm{m}}$ values within the 30 -fold increase of salt concentration. The fully modified duplex S6:S7 increased its $T_{\mathrm{m}}$ by $35^{\circ} \mathrm{C}$, which is slightly more than twice the starting value at $0.05 \mathrm{M} \mathrm{NaCl}$. We further determined the relative counter ion uptake $\Delta \mathrm{n}$ (Table 5) according to classical polyelectrolyte theory ${ }^{[17]}$ using the transition enthalpy $(\Delta \mathrm{H})$ data from Table 4.

$$
\Delta \mathrm{n}=-2 \Delta \mathrm{H} / \mathrm{R} T_{\mathrm{m}}{ }^{2} * \delta T_{\mathrm{m}} / \delta(\ln [\mathrm{NaCl}])
$$

Table 5. Calculated counter ion uptake. Conditions: $10 \mathrm{mM} \mathrm{NaH} \mathrm{PO}_{4}, 200 \mathrm{mM} \mathrm{NaCl}$, pH 7

\begin{tabular}{llll}
\hline & $\mathrm{S} 8: \mathrm{S} 9$ & $\mathrm{~S} 6: \mathrm{S} 9$ & $\mathrm{S6}: \mathrm{S} 7$ \\
\hline$\Delta \mathrm{n}$ & 1.1 & 1.6 & 2.1 \\
$\delta \mathrm{T}_{\mathrm{m}} / \delta(\ln [\mathrm{NaCl}])$ & 5.3 & 7.2 & 11.8 \\
\hline
\end{tabular}

The fully modified iso-bc system S6:S7 screens about twice as much counter ions upon duplex formation than the corresponding unmodified duplex and about a third more than the hybrid duplex. This is in agreement with a higher degree of spatial compression of the phosphate groups upon transition from single strands to duplex. Whether this is due to a more compressed duplex structure or a more relaxed single strand structure remains unknown at this point.

Synthesis and properties of oligonucleotides containing all four iso-bc-nucleosides: Two fully modified sequences containing iso-bc-A, $-\mathrm{T},-\mathrm{G}$, and $-\mathrm{C}$ residues were synthesized: A dodecamer (S10) for the investigation of the pairing properties with complementary DNA and RNA and a self-complementary hexamer (S11) to get further insight into the structure of fully modified duplexes (Table 6). Thermal melting of S10 with complementary DNA shows, as all modified DNA sequences, a cooperative and reversible melting behavior (Figure 6). Again, a stabilization of the duplex was observed but, even including the more stable CG base pairs, the difference in melting temperature is small $\left(+4^{\circ} \mathrm{C} /\right.$ duplex $)$ and comparable to the one observed in the AT-series (Table 6). In addition, the melting behavior of S10 with a parallel DNA complement was investigated. No cooperative transition was observed revealing that iso-bc-DNA, as DNA, strongly prefers antiparallel Watson-Crick pairing in sequences containing all four base-pairs. For the hexamer S11 a very stable duplex was found with for GC base-pairs usually low hyperchromicities at $260 \mathrm{~nm}$
(Figure 6). This again confirms that fully modified iso-bc-duplexes are very stable, irrespective of the base composition.

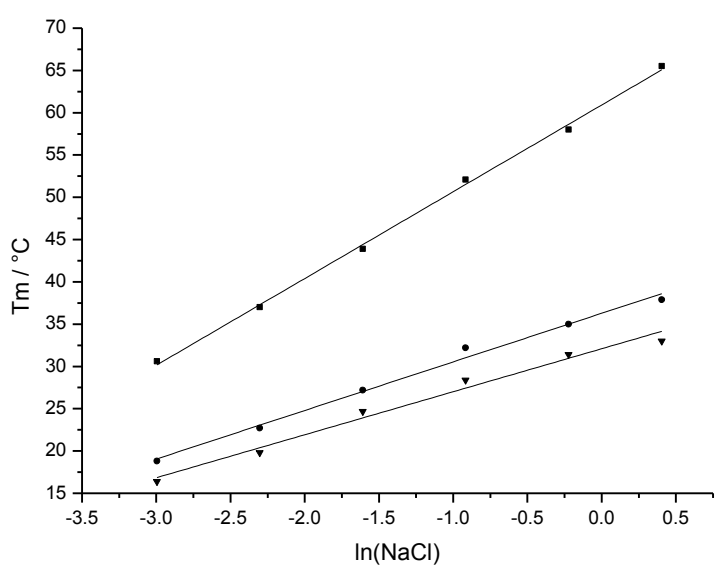

Figure 5. Plot of the $T_{\mathrm{m}} \mathrm{vs} \ln [\mathrm{NaCl}] ; 10 \mathrm{mM} \mathrm{NaH} \mathrm{PO}_{4}, 50 \mathrm{mM}-1.5 \mathrm{M} \mathrm{NaCl}, \mathrm{PH}=7.0$ $\mathrm{c}=1.2 \mu \mathrm{M}$ strand concentration. $\boldsymbol{\nabla}$ DNA:DNA, $\bullet \mathbf{S 6 : S 7 , \bullet ~ S 6 : D N A ~}$

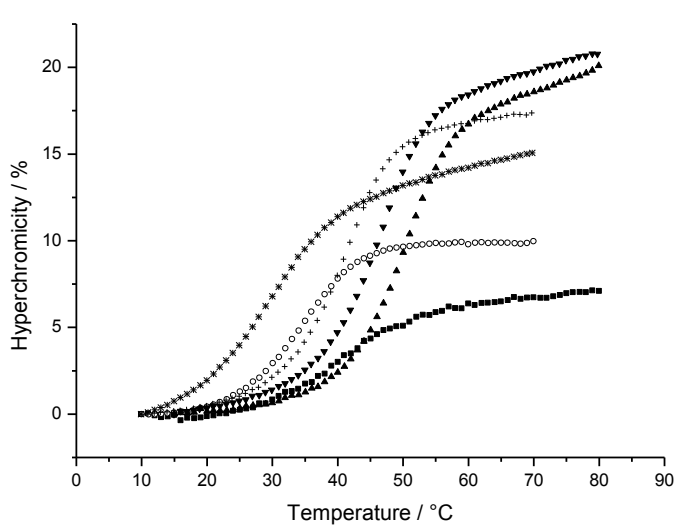

Figure 6. UV melting curves $(260 \mathrm{~nm})$ for the modified sequence $\mathrm{S} 7$ with DNA (left) and RNA (right). Conditions: $10 \mathrm{mM} \mathrm{NaH}_{2} \mathrm{PO}_{4}, 150 \mathrm{mM} \mathrm{NaCl}, \mathrm{pH} 7.0, \mathrm{c}=1.2 \mu \mathrm{M}$ strand concentration. - S11, ○ RNA hexamer, $\triangle$ S10:DNA, $\boldsymbol{\nabla}$ DNA:DNA, * S10:RNA, + DNA:RNA

Table 6. $T_{\mathrm{m}}$ data for fully modified iso-bc-oligonucleotides containing all four bases. Conditions: $10 \mathrm{mM} \mathrm{NaH} \mathrm{PO}_{4}, 150 \mathrm{mM} \mathrm{NaCl}, \mathrm{pH} 7.0$, strand concentration for all dodecamers: $\mathrm{c}=1.2 \mu \mathrm{M}$. Total strand concentration for the natural hexamers: $2.4 \mu \mathrm{M}$ and for S11: $4.8 \mu \mathrm{M}$

\begin{tabular}{lllll}
\hline & Sequence & $\begin{array}{l}\text { DNA } \\
\text { antiparallel }\end{array}$ & $\begin{array}{l}\text { RNA } \\
\text { antiparallel }\end{array}$ & $\begin{array}{l}\text { iso-bc } \\
\text { duplex }\end{array}$ \\
\hline S10 & $6^{\prime}$-d(cctactagagct)-3' & $51.0(+4)$ & $30.0(-11.5)$ & -- \\
S11 & $6^{\prime}$-d(cctagg)-3, ${ }^{\left[b^{b}\right]}$ & $<10$ & 34.5 & 40.7 \\
\hline
\end{tabular}

[a] n.d.: not detected [b] self-complementary duplex: $T_{m}$ data refer to the resp. backbone type.

CD spectra of the hybrid duplex (S10:DNA, Figure 7) revealed a completely different curve shape compared to the unmodified duplex (Figure S13, supplementary information), indicating substantial deviation from classical A or B-type structures. In contrast, in the case of the RNA complement, a typical A-form is observed with comparable spectra for the unmodified and the modified duplex. The CD signature of the S11:S11 duplex, however, shows an intense negative cotton effect at $290 \mathrm{~nm}$ and a positive cotton effect at $260 \mathrm{~nm}$ (Figure 7). It thus deviates significantly from that of the self-complementary RNA hexamer (A- 
type conformation, data not shown) and also to some extent from the fully modified iso-bc-AT duplex S6:S7 (Figure 3). It thus shows

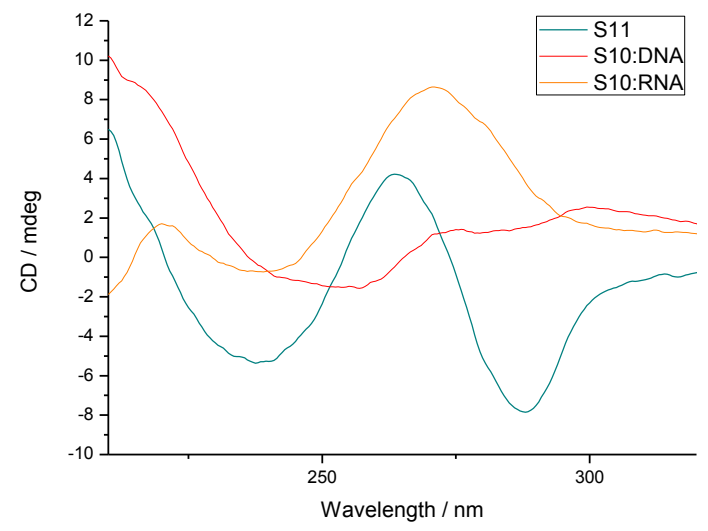

Figure 7. CD spectra of S11:S11, S10:DNA and S10:RNA. Conditions: $10 \mathrm{mM}$ $\mathrm{NaH}_{2} \mathrm{PO}_{4}, 150 \mathrm{mM} \mathrm{NaCl}, \mathrm{pH} 7, \mathrm{c}=1.2 \mu \mathrm{M}$ strand concentration.

some similarities to that of Z-DNA ${ }^{[18]}$ which, given the high GC content, could be a possible structure for S11. However, more high resolution structural work is needed to get a reliable picture of the 3D structure.

Mismatch discrimination: To test the base-pairing selectivity of the iso-bc-DNA system, the melting temperatures of different mismatched duplexes complementary to S10 were measured. A thymidine residue in the complementary DNA sequence was replaced by an A, C or $\mathrm{G}$ and the corresponding $T_{\mathrm{m}}$ values were determined (Table 7).

Table 7. Mismatch discrimination. In parentheses are the $\Delta \mathrm{T}_{\mathrm{m}}$ values relative to the matched duplex. Conditions: $10 \mathrm{mM} \mathrm{NaH} 2 \mathrm{PO}_{4}, 150 \mathrm{mM} \mathrm{NaCl}, \mathrm{pH} 7.0, \mathrm{c}=1.2 \mu \mathrm{M}$ strand concentration.

\begin{tabular}{lllll}
\hline duplex & $\mathrm{X}=\mathrm{A}$ & $\mathrm{X}=\mathrm{G}$ & $\mathrm{X}=\mathrm{C}$ & $\begin{array}{l}\mathrm{X}=\mathrm{T} \\
\text { (match) }\end{array}$ \\
\hline 6'-d(cctactagagct)-3' (S10) & $37(-14)$ & $43(-8)$ & $33(-18)$ & 51 \\
5'-d(ACGXCTTGTAGG)-3' & & & & \\
\hline 5'-d(CCTACAAGAGCT)-3' & $34(-13)$ & $39(-8)$ & $30(-17)$ & 47 \\
5'-d(ACGXCTTGTAGG)-3' & & & & \\
\hline
\end{tabular}

In all cases thermal destabilizations in the mismatched duplexes were observed. The A-C mismatch was the strongest discriminating followed by the A-A and the A-G mismatches. The decrease is generally of about the same extent as in DNA, indicating an equal selectivity of the two Watson-Crick pairing systems.

Serum stability: The serum stability of $\mathbf{S 1 0}$ was measured in heat deactivated fetal bovine serum (FBS) in which the predominant nucleases are the 3 '-exophosphodiesterases. ${ }^{[19]}$ As a control the stability of the corresponding natural DNA complement was tested, too. After incubation at $37^{\circ} \mathrm{C}$ in medium containing $10 \%$ FBS, aliquots were taken in regular intervals and after ethanol preciptiation analysed by PAGE. The gel was visualized with stainsall solution (Figure 8).

The resulting gel shows that $\mathbf{S 1 0}$ is stable over a period of at least $21 \mathrm{~h}$ without signs of degradation. In contrast, the DNA complement is substantially hydrolyzed after this period of time, indicating a significantly higher degree of biostability of iso-bc-DNA.

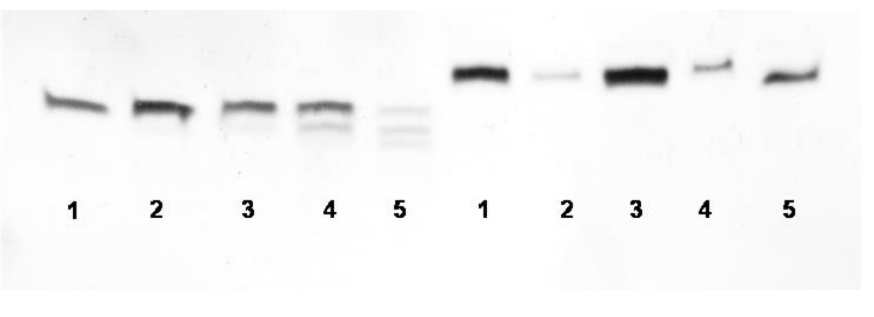

Figure 8. PAGE analysis of the serum stability of DNA (left) and iso-bicyclo DNA (right). 1: $0 \mathrm{~h}, 2: 0.5 \mathrm{~h}, 3: 2 \mathrm{~h}, 4: 6.5 \mathrm{~h}, 5: 21 \mathrm{~h}$

RNase H activity: Due to its ability to cleave DNA/RNA heteroduplexes, it is desirable for chemically modified oligonucleotides designed to ablate an RNA of interest, to be able to activate the endogenous enzyme RNase $H$. This is, however, difficult to achieve since only a small number of DNA analogues is known to be compatible with RNase $\mathrm{H}$ activity. ${ }^{[20]}$ To investigate this, the RNA complement of $\mathbf{S 1 0}$ was 5'-labeled with $\left[\gamma^{-32} \mathrm{P}\right]$-ATP and T4 polynucleotide kinase (T4 PNK) and annealed to S10. The natural RNA/RNA and the hybrid DNA/RNA duplexes served as negative and positive control. As expected, the RNA/RNA duplex did not show any RNase $\mathrm{H}$ mediated degradation, while the DNA/RNA hybrid turned out to be a good substrate. The S10/RNA duplex showed no signs of RNA cleavage after treatment with RNaseH, clearly showing that iso-bc-DNA does not elicit RNaseH activity (Figure 9).

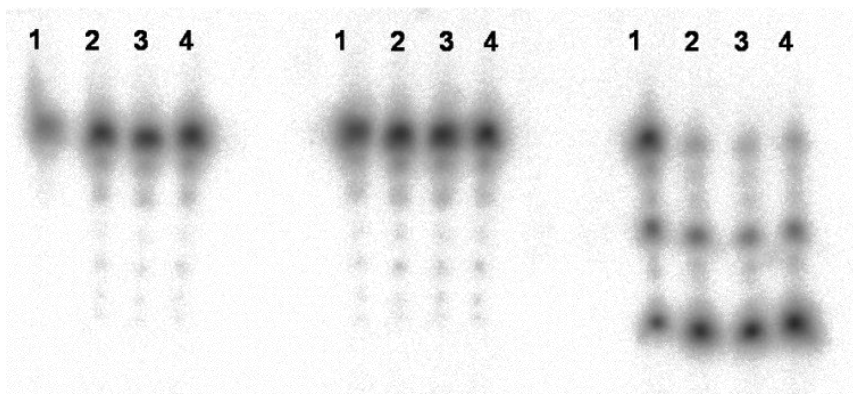

Figure 9 PAGE analysis of the RNase $\mathrm{H}$ acitvity of the duplexes: RNA:32P-RNA (C12:32P-C9), iso-bicyclo-DNA:32P-RNA (S7:32P-C9), DNA:32P-RNA (C8:32P-C9). 1: $5 \mathrm{~min} ., 2: 45 \mathrm{~min} ., 3: 120 \mathrm{~min} ., 4: 300 \mathrm{~min}$.

\section{Discussion}

We synthesized all four iso-bicyclo nucleosides and incorporated them successfully into DNA. Single iso-bicyclo T incorporations in natural DNA showed stable duplexes with complementary DNA and RNA. Consecutive incorporations destabilize the RNA hybrid. The same result was obtained for the fully modified AT duplexes where a stabilized duplex with DNA and a significantly destabilized duplex with complementary RNA was found. An interesting finding in the AT series was the very stable self-duplex with a $T_{\mathrm{m}}$ of $41.9^{\circ} \mathrm{C}$. The CD spectrum of this fully modified iso-bicyclo duplex (Figure 3) revealed a structure different from A- or B-form duplex.

It is known that the duplex conformation as revealed by CDspectroscopy is dependent on the base sequence and on the salt concentration of the buffer. Increasing the salt concentration typically leads to a decrease of the long wavelength band between 290 and $260 \mathrm{~nm}$ corresponding to variants of B-DNA structures differing in the number of base pairs per helix turn. ${ }^{[21]}$ Vorlíčková 
and Kypr investigated the conformational changes of poly(A-T) sequences at different $\mathrm{CsF}$ concentrations and found that the long wavelength part of the $\mathrm{CD}$ spectra falls off, inverts and becomes negative at high salt concentrations. ${ }^{[22]}$ They called that structure $\mathrm{X}$ DNA and suggested that this X-DNA is a right handed anti-parallel double helix with Hoogsteen base-pairs that were found by Abrescia et al. some years ago. ${ }^{[21,23]}$ In this Hoogsteen $\mathrm{DNA}^{[23]}$ the overall helical parameters are similar to that of B-DNA with the adenines in syn-conformation. Therefore one hypothesis is that the fully modified iso-bicyclo-AT duplex S6:S7 forms such an X-DNA structure.

Further evidence for such a X-DNA structure comes from CDexperiments with $\mathbf{S 6 : S 7}$ as well as the hybrid DNA duplexes of S6 at different salt concentrations. While no major changes occur in the case of the unmodified duplex S8:S9 and the hybrid duplex S6:S9 (Figures S7 and S8, supplementary information), the CD of the fully modified duplex S6:S7 shows a high dependence on the sodium chloride concentration (Figure S10, supplementary information). The negative band at $275 \mathrm{~nm}$ increases in intensity upon increasing the $\mathrm{NaCl}$ concentration. This could indeed be an indication of a partial structural transition from the more compact X-towards a Btype conformation when changing from high to low electrolyte concentration, which supports the preference of an X-type conformation of iso-bc-DNA duplexes at physiological salt concentration.

The fully modified iso-bc-AT oligonucleotides form also stable parallel duplexes. Parallel duplex formation in poly(dAT) sequences is well known and investigated. ${ }^{[15,24]}$ They require reversed WatsonCrick base-pairs and their thermal stability is highly sequence dependent. This explains the variability in the $T_{\mathrm{m}} \mathrm{s}$ for the two duplexes S6 and S7 with parallel complements. However, no melting transition was found for the fully modified S10, containing all four bases, with a parallel DNA complement, revealing that isobc-DNA prefers strictly antiparallel pairing in sequences containing also G-C base-pairs. These preferences are identical to that of natural DNA where parallel reversed Watson Crick is also restricted to AT sequences.

Iso-bc-DNA was found to be unable to activate RNase $\mathrm{H}$ in isobc-DNA/RNA hybrids. RNase $\mathrm{H}$ is known to preferably bind to Aform rather than B-form duplexes. Hence, as a consequence the enzyme binds RNA/RNA duplexes and DNA/RNA hybrids much tighter than a DNA/DNA duplex. ${ }^{[25]}$ The RNA in dsRNA duplexes is not cleaved since the 2'-OH groups affect the hydration pattern in the minor groove. ${ }^{[26]}$ Since the CD spectrum of the iso-bicyclo DNA/RNA duplex shows an A-like structure and is very similar to that of the DNA/RNA duplex, an activation of RNase $\mathrm{H}$ could have been expected. However, it has also been shown that the enzyme is very sensitive to structural changes within the minor groove. This is the reason why all $2^{\prime}$ ' modified oligonucleotides (e.g. 2'-OMe ${ }^{[27]}$ ) as well as the sterically constrained (e.g. $\mathrm{LNA}^{[28]}$; tcDNA ${ }^{[9]}$ ) do not activate RNase $\mathrm{H}^{[26]}$ From this point of view it is not surprising that iso-bc-DNA is unable to do so.

\section{Conclusions}

We have achieved the synthesis of all four iso-bc-DNA building blocks starting from the silyl enolethers $\mathbf{1 a}$ or $\mathbf{1 b}$. These phosphoramidites were successfully incorporated into natural deoxyoligonucleotides or were used for the synthesis of fully modified iso-bc-DNA by standard solid phase DNA synthesis. Oligodeoxynucleotides containing single incorporations as well as fully modified iso-bc-DNA show stable duplexes with DNA complements with a slightly enhanced stability (ca. $0.3{ }^{\circ} \mathrm{C} / \mathrm{mod}$ ). RNA is discriminated as complement in all the investigated duplexes by ca $1{ }^{\circ} \mathrm{C} /$ mod. All hybrid duplexes show B-conformation with DNA and A-conformation with RNA as judged from CDexperiments. Base mismatches are discriminated in the same way as in natural DNA. Fully modified iso-bicyclo oligonucleotides form very stable duplexes within their own backbone series that are of higher thermodynamic stability than the corresponding natural duplexes. Fully modified duplexes containing only AT base-pairs show a CD-signature that is significantly different from that of the canonical DNA conformations. Based on the available biophysical data we propose a double helical structure with Hoogsteen basepairs. Furthermore, iso-bc-DNA is stable in bovine serum and does not activate RNase $\mathrm{H}$.

Thus it appears that the phosphate shift from $\mathrm{C}\left(5^{\prime}\right)$ to $\mathrm{C}\left(6^{\prime}\right)$ in the bicyclic system is well tolerated in duplexes with DNA and less well in duplexes with RNA. Pure iso-bc-DNA duplexes, however, display considerable structural differences of a yet unknown type. The feature of iso-bc-DNA to stablize DNA duplexes and discriminate RNA is interesting and could find possible applications in diagnostics, as e.g. in primers for PCR.

\section{Experimental Section}

General: All reactions were performed under Ar and in dried glassware. Anhydrous solvents for reactions were obtained by filtration through activated alumina or by storage over molecular sieves (4 ̊). Column chromatography (CC) was performed on silica gel with an average particle size of $40 \mu \mathrm{m}$. All solvents for column chromatography were of technical grade and distilled prior to use. Thin-layer chromatography was performed on silica gel plates. Visualization was achieved either under UV light or by dipping in staining solution [CerIV-sulfate $(10.5 \mathrm{~g})$, phosphormolybdenic acid $(21 \mathrm{~g})$, conc. $\mathrm{H}_{2} \mathrm{SO}_{4}(60 \mathrm{ml}), \mathrm{H}_{2} \mathrm{O}(900 \mathrm{ml})$ or p-anisaldehyde $(10 \mathrm{ml})$, conc. $\mathrm{H}_{2} \mathrm{SO}_{4}(10 \mathrm{ml})$, glacial acetic acid $(2 \mathrm{ml})$, ethanol $\left.(180 \mathrm{ml})\right]$ followed by heating with a heat gun. NMR spectra were recorded at 300 or $400 \mathrm{MHz}$ field width $\left({ }^{1} \mathrm{H}\right)$ in either $\mathrm{CDCl}_{3}$ or $\mathrm{CD}_{3} \mathrm{OD}$. $\delta$ in ppm relative to residual undeuterated solvent $\mathrm{CHCl}_{3}: 7.26 \mathrm{ppm}\left({ }^{1} \mathrm{H}\right)$ and $77.16 \mathrm{ppm}\left({ }^{13} \mathrm{C}\right) ; \mathrm{CHD}_{2} \mathrm{OD}: 3.31 \mathrm{ppm}\left({ }^{1} \mathrm{H}\right)$ and $49.0 \mathrm{ppm}$ $\left({ }^{13} \mathrm{C}\right)$, $\mathrm{J}$ in $\mathrm{Hz}$. Signal assignments are based on DEPT and on ${ }^{1} \mathrm{H}-{ }^{1} \mathrm{H}$ and ${ }^{1} \mathrm{H}^{-13} \mathrm{C}$ correlation experiments (COSY/HMSC). High-resolution mass spectra were recorded on an Applied Biosystems Sciex QSTAR Pulsar.

$(3 R, \quad 5 S, \quad 8 R, \quad 7 S)-8-(($ tert-butyldimethylsilyl)oxy)-3-methoxyhexahydro-2Hcyclopenta[b]furan-3a,6-diyl diacetate $4 \mathbf{b}$ A solution of $2 \mathbf{b}(4.3 \mathrm{~g}, 14.2 \mathrm{mmol})$ in pyridine $(35 \mathrm{ml})$ was cooled to $0^{\circ} \mathrm{C}$ and DMAP $(171 \mathrm{mg}, 1.4 \mathrm{mmol})$ and $\mathrm{Ac}_{2} \mathrm{O}(4.0 \mathrm{ml}$, $42.7 \mathrm{mmol}$ ) were added. The mixture was stirred for $16 \mathrm{~h}$ at r.t. and, after cooling to $0^{\circ} \mathrm{C}$, carefully quenched and washed with sat. $\mathrm{NaHCO}_{3}$. The aqueous layers were extracted with DCM. The combined organic layers were dried over $\mathrm{MgSO}_{4}$ and evaporated. FC (ethyl acetate/hexane 1:3) yielded $\mathbf{4 b}(4.9 \mathrm{~g}, 12.6 \mathrm{mmol}, 90 \%)$ as a white solid. $\mathrm{R}_{\mathrm{f}}$ : 0.9 (hexane/ethyl acetate 1:1), HR-MS $\left(\mathrm{NSI}^{+}, \mathrm{MeCN}\right.$ ) for $\mathrm{C}_{18} \mathrm{H}_{32} \mathrm{O}_{7} \mathrm{Si}$. calc: 411.1813 , found: $411.1810\left(\mathrm{M}+\mathrm{Na}^{+}\right),{ }^{1} \mathrm{H}$ NMR $\left(400 \mathrm{MHz}, \mathrm{CDCl}_{3}\right) \delta 5.24(\mathrm{~m}$, $1 \mathrm{H}), 5.06(d, 1 \mathrm{H}, J=5.3), 4.36(d, 1 \mathrm{H}, J=6.4), 4.20(d d, 1 \mathrm{H}, J=8.6,6.4), 3.36(s, 3 \mathrm{H})$, $2.86(d d, 1 \mathrm{H}, J=13.9,7.6), 2.55(d, 1 \mathrm{H}, \mathrm{J}=13.8), 2.36(d d d, 1 \mathrm{H}, J=13.8,5.7,1.8)$, $2.02(s, 6 \mathrm{H}), 1.76(d d d, 1 \mathrm{H}, J=13.8,9.7,1.6), 0.90(s, 9 \mathrm{H}), 0.11(s, 3 \mathrm{H}), 0.08(s$, $3 \mathrm{H}) .{ }^{13} \mathrm{C} \mathrm{NMR}\left(101 \mathrm{MHz}, \mathrm{CDCl}_{3}\right) \delta 170.55,170.17,105.42,89.29,85.33,77.97,75.80$, $54.62,47.69,40.15,25.89,21.62,21.16,-4.60,-4.71$

$(3 R, \quad 5 S, \quad 8 R, \quad 7 S)-8-h y d r o x y-3-m e t h o x y h e x a h y d r o-2 H$-cyclopenta[b]furan-3a,6-diyl diacetate $\boldsymbol{6} \boldsymbol{b}$ A solution of $\mathbf{4 b}(10.4 \mathrm{~g}, 26.8 \mathrm{mmol})$ in THF $(80 \mathrm{ml})$ was cooled to $0^{\circ} \mathrm{C}$. $\mathrm{HF} / \mathrm{Et}_{3} \mathrm{~N}(37 \% \mathrm{HF}, 23 \mathrm{ml}, 53.6 \mathrm{mmol})$ was added and the solution was allowed to warm to r.t. The reaction mixture was stirred for $60 \mathrm{~h}$ at r.t. and subsequently quenched with silica. The solvent was evaporated and the crude mixture purified by FC (ethyl acetate/hexane 1:1). 6b (5.9 g, $21.5 \mathrm{mmol}, 80 \%)$ was obtained as a colourless oil. $\mathrm{R}_{\mathrm{f}} 0.4$ (ethyl acetate/hexane 1:1), HR-MS $\left(\mathrm{NSI}^{+}, \mathrm{MeCN} / \mathrm{H}_{2} \mathrm{O}, 1 \% \mathrm{HF}\right.$ ) for $\mathrm{C}_{12} \mathrm{H}_{18} \mathrm{O}_{7}$. calc: 279.09447, found: $297.09538\left(\mathrm{M}+\mathrm{Na}^{+}\right),{ }^{1} \mathrm{H}-\mathrm{NMR}\left(300 \mathrm{MHz}, \mathrm{CDCl}_{3}\right): 5.10-5.13(\mathrm{~m}$ $2 \mathrm{H}), 4.53(d, \mathrm{~J}=6.4,1 \mathrm{H}), 4.10(m, 1 \mathrm{H}), 3.39(s, 3 \mathrm{H}) ; 2.78-2.80(m, 2 \mathrm{H}), 2.48(m, 2 \mathrm{H})$, $2.03(s, 3 \mathrm{H}) ; 2.00(s, 3 \mathrm{H}), 1.95-1.86(m, 1 \mathrm{H}),{ }^{13} \mathrm{C}$ NMR $\left(75 \mathrm{MHz}, \mathrm{CDCl}_{3}\right) \delta 171.06$, $170.09,106.93,89.23,85.93,78.71,74.79,55.79,47.14,39.93,21.51,21.14$ 
$(3 R, \quad 5 S, \quad 8 R, \quad 7 S)-8-((1 H$-imidazole-1-carbonthioyl)oxy)-3-methyoxyhexahydro-2Hcyclopenta[b]furan-3a,6-diyl diacetate $8 \boldsymbol{b}$ To a solution of $\mathbf{6 b}(3.2 \mathrm{~g}, 11.7 \mathrm{mmol})$ in THF $(60 \mathrm{ml})$ was added TCDI $(4.2 \mathrm{~g}, 23.3 \mathrm{mmol})$. The yellow solution was refluxed at $75^{\circ} \mathrm{C}$ for $3 \mathrm{~h}$. The THF was then evaporated and the crude mixture was purified by FC (ethyl acetate/hexane $1: 1)$ to yield $\mathbf{8 b}(4.2 \mathrm{~g}, 10.9 \mathrm{mmol}, 93 \%)$ as a yellow foam. $\mathrm{R}_{\mathrm{f}} 0.40$ (ethyl acetate/hexane 1:1), HR-MS (NSI ${ }^{+}$, EtOAc) for $\mathrm{C}_{16} \mathrm{H}_{20} \mathrm{~N}_{2} \mathrm{O}_{7} \mathrm{~S}$. calc: 385.1064 found: $385.1051\left(\mathrm{M}+\mathrm{H}^{+}\right),{ }^{1} \mathrm{H}$ NMR $\left(400 \mathrm{MHz}, \mathrm{CDCl}_{3}\right) \delta 8.39(m, 1 \mathrm{H}) 7.67(m, 1 \mathrm{H})$ $7.04(m, 1 \mathrm{H}) 5.92-5.85(m, 1 \mathrm{H}) 5.70-5.67(m, 1 \mathrm{H}), 5.08,5.06(2 m, 2 \mathrm{H}) 3.34(s, 3 \mathrm{H})$, $2.94(d d, 1 \mathrm{H}, J=13.9,8.1), 2.58(d, 1 \mathrm{H}, J=14.0), 2.49(d d d, 1 \mathrm{H}, J=14.1,5.7,1.8)$ 2.14-2.10 (m, 1H) 2.08, $2.05(2 s, 6 \mathrm{H}) .{ }^{13} \mathrm{C}$ NMR $\left(101 \mathrm{MHz}, \mathrm{CDCl}_{3}\right) \delta 183.54,170.40$, $170.29,137.40,131.24,118.26,106.14,89.25,84.34,82.33,73.85,55.33,47.82,39.38$ $21.55,21.15$

(3R, 5S, 7S)-3-methoxyhexahydro-2H-cyclopenta[blfuran-3a,6-diyl diacetate $\mathbf{1 0 b}$ The sugar $8 \mathbf{b}(4.2 \mathrm{~g}, 10.9 \mathrm{mmol})$, AIBN (270 mg, $2.2 \mathrm{mmol})$ and TTMSS $(6.7 \mathrm{ml}, 22 \mathrm{mmol})$ were dissolved in toluene $(87 \mathrm{ml})$ and stirred for $2 \mathrm{~h}$ at $85^{\circ} \mathrm{C}$. The toluene was then evaporated and the crude mixture purified by FC (ethyl acetate/hexane 1:3). Compound 10b (2.6 g, $10.1 \mathrm{mmol}, 92 \%$ ) was obtained as a colourless oil. $\mathrm{R}_{\mathrm{f}} 0.6$ (ethy acetate/hexane 1:1), HR-MS $\left(\mathrm{NSI}^{+}, \mathrm{MeOH}\right)$ for $\mathrm{C}_{12} \mathrm{H}_{18} \mathrm{O}_{6}$. calc: 281.0996, found $281.1002\left(\mathrm{M}+\mathrm{Na}^{+}\right),{ }^{1} \mathrm{H} \mathrm{NMR}\left(300 \mathrm{MHz}, \mathrm{CDCl}_{3}\right) \delta 5.39-5.31(p, 1 \mathrm{H}, J=6.3), 5.04(d d$ $1 \mathrm{H}, J=5.6,0.7), 4.71(d d, 1 \mathrm{H}, J=7.0,3.5) 3.33(s, 3 \mathrm{H}), 2.78-2.71(d d, 1 \mathrm{H}, J=14.6$ $6.2), 2.60(d, 1 \mathrm{H}, J=14.0), 2.33(d d d, 1 \mathrm{H}, J=14.2,5.7,0.8), 2.29-2.07(m, 3 \mathrm{H}) 2.02$ $2.00(2 s, 6 \mathrm{H}) .{ }^{13} \mathrm{C}$ NMR $\left(75 \mathrm{MHz}, \mathrm{CDCl}_{3}\right) \delta 170.58,170.37,106.61,92.63,87.86$ $75.03,54.99,46.55,44.15,39.02,21.65,21.28$.

(3'S, 6'S (6'R))-1-(3', 6'-Di-O-acetyl-2'-deoxy-3',5'-ethano- $\alpha$ - and - $\beta$-D-ribofuranosyl] thymine $12 a / b$ Thymine (293 mg, $2.3 \mathrm{mmol}$ ) was suspended in MeCN (12 ml) and BSA $(1.4 \mathrm{ml}, 5.8 \mathrm{mmol})$ was added. The suspension was stirred until the solution became clear. The solution was then cooled to $0^{\circ} \mathrm{C}$ and $10 \mathrm{~b}(300 \mathrm{mg}, 1.2 \mathrm{mmol}$, dissolved in 6 $\mathrm{ml} \mathrm{MeCN})$ and TMSOTf $(0.63 \mathrm{ml}, 3.5 \mathrm{mmol})$ were added. After $1 \mathrm{~h}$ at $0^{\circ} \mathrm{C}$ the mixture was allowed to warm to r.t. and the stirring was continued for another $16 \mathrm{~h}$. It was then diluted with ethyl acetate and washed with sat. $\mathrm{NaHCO}_{3}$. Purification by $\mathrm{FC}$ (ethyl acetate/hexane $4: 1$ ) yielded the desired nucleoside $\mathbf{1 2 a} / \mathbf{b}(355 \mathrm{mg}, 1.0 \mathrm{mmol}, 87 \%)$ in anomeric ratio of approx. $\alpha / \beta \quad 1: 1$ as a white foam. $\mathrm{R}_{\mathrm{f}} 0.49$ (ethyl acetate/hexane $4: 1$ ), HR-MS ( $\left.\mathrm{NSI}^{+}, \mathrm{MeCN}\right)$ for $\mathrm{C}_{16} \mathrm{H}_{20} \mathrm{~N}_{2} \mathrm{O}_{7}$. Calc. 375.1163, found $375.1145\left(\mathrm{M}+\mathrm{Na}^{+}\right),{ }^{1} \mathrm{H}$ NMR $\left(400 \mathrm{MHz}, \mathrm{CDCl}_{3}\right) \delta 8.29(m, 2 \mathrm{H}), 7.27(s, 1 \mathrm{H}), 7.11(s, 1 \mathrm{H}), 6.12(m, 2 \mathrm{H}), 5.23$ $(m, 2 \mathrm{H}), 4.93(d d, 1 \mathrm{H}, J=6.4,3.1), 4.56(\mathrm{~d}, 1 \mathrm{H}, J=5.6), 2.86(m, 2 \mathrm{H}), 2.79(\mathrm{~d} d d, 1 \mathrm{H}, J$ $=13.8,6.3,1.3), 2.66(m, 1 \mathrm{H}), 2.54(m, 1 \mathrm{H}), 2.36(m, 1 \mathrm{H}), 2.25(m, 2 \mathrm{H}), 2.16(m, 1 \mathrm{H})$ $2.10(m, 2 \mathrm{H}), 2.08(s, 3 \mathrm{H}), 2.06(s, 3 \mathrm{H}), 2.04(2 s, 6 \mathrm{H}), 2.00(m, 1 \mathrm{H}) 1.96(m, 3 \mathrm{H}), 1.95$ $(m, 3 \mathrm{H}) .{ }^{13} \mathrm{C}$ NMR $(75 \mathrm{MHz}, \mathrm{CDCl} 3) \delta 170.69,170.49,170.35,170.15,163.73,163.44$, $150.30,150.28,135.31,134.44,112.04,111.11,91.21,90.17,87.69,86.78,85.33$ $83.74,73.65,73.23,44.46,44.35,43.64,43.37,37.84,36.47,21.73,21.63,21.19$ $21.16,12.86,-1.73$

(3'S, 6'S)-N6-Benzoyl-9-(3', 6'-Di-O-acetyl-2'-deoxy-3';5'-ethano- $\alpha$ - and $-\beta$ - $D$ ribofuranosyl] adenine $\mathbf{1 3 a / b}$ To a suspension of N6-benzoyl-adenine (926 $\mathrm{mg}, 3.9$ $\mathrm{mmol})$ in $\mathrm{MeCN}(15 \mathrm{ml})$ was added BSA $(1.9 \mathrm{ml}, 7.6 \mathrm{mmol})$. The mixture was stirred at r.t. until the solution was clear. $10 \mathrm{~b}(500 \mathrm{mg}, 1.9 \mathrm{mmol}$, solved in $4 \mathrm{ml} \mathrm{MeCN})$ and TMSOTf $(0.1 \mathrm{ml}, 0.6 \mathrm{mmol})$ were added and the solution was stirred for $2 \mathrm{~h}$ at $85^{\circ} \mathrm{C}$ After cooling to r.t. the mixture was quenched with sat. $\mathrm{NaHCO}_{3}$ and extracted with ethyl acetate. The combined organic layers were dried over $\mathrm{MgSO}_{4}$ and evaporated. $\mathrm{FC}$ (3\% methanol in DCM) yielded $\mathbf{1 3 a} / \mathbf{b}(654 \mathrm{mg}, 1.4 \mathrm{mmol}, 74 \%)$ in an anomeric ration of $\sim 1: 1$ as a white foam. $\mathrm{R}_{\mathrm{f}} 0.65\left(10 \%\right.$ methanol in DCM), HR-MS $\left(\mathrm{NSI}^{+}, \mathrm{MeOH}\right)$ for $\mathrm{C}_{23} \mathrm{H}_{23} \mathrm{~N}_{5} \mathrm{O}_{6}$. calc: 466.1721 , found: $466.1724\left(\mathrm{M}+\mathrm{H}^{+}\right),{ }^{1} \mathrm{H}$ NMR $\left(300 \mathrm{MHz}, \mathrm{CDCl}_{3}\right)$ $8.81,8.79(2 s, 2 \mathrm{H}) 8.24,8.15,(2 s, 2 \mathrm{H}) 8.03(m, 4 \mathrm{H}), 7.64-7.59(m, 2 \mathrm{H}), 7.55-7.50(m$ $4 \mathrm{H}), 6.45(d d, 1 \mathrm{H}, J=6.9,2.7), 6.34(d d, 1 \mathrm{H}, J=8.4,6.4), 5.55-5.46\left(m, 1 \mathrm{H}, \mathrm{H}-\mathrm{C}\left(6^{\prime}\right)\right.$ B), 5.31-5.21 (m, 1H), $4.89(d d, 1 \mathrm{H} J=6.1,1.0), 4.73(d d, 1 \mathrm{H}, J=6.5,1.7), 3.44(d d$, $1 \mathrm{H}, J=15.4,2.7), 3.03-2.90(m, 4 \mathrm{H}), 2.88-2.81(m, 1 \mathrm{H}) 2.45-2.36(m, 2 \mathrm{H}), 2.22-2.12$ $(m, 4 \mathrm{H}), 2.12(s, 3 \mathrm{H}), 2.06,2.05(2 s, 6 \mathrm{H}), 1.95(s, 3 \mathrm{H}) .{ }^{13} \mathrm{C} \mathrm{NMR}\left(101 \mathrm{MHz}, \mathrm{CDCl}_{3}\right) \delta$ $170.60,170.55,170.47,170.21,164.72,153.09,152.97,149.89,149.72,141.43$ $141.25,133.85,133.07,133.03,129.13,128.07,123.67,91.03,90.99,87.65,86.25$ $85.85,84.84,77.55,77.23,76.91,73.46,73.26,44.25,44.17,43.77,37.02,36.88$ $21.81,21.52,21.23,21.18$

(3'S, 6'S)-N6-Benzoyl-1-(3', 6'-Di-O-acetyl-2'-deoxy-3',5'-ethano- $\alpha$ - and $-\beta$-D ribofuranosyl) cytosine $14 a / b$ N-Benzoylcytosine $(833 \mathrm{mg}, 3.9 \mathrm{mmol})$ was suspended in $\mathrm{MeCN}(20 \mathrm{ml})$, BSA $(2.3 \mathrm{ml}, 9.5 \mathrm{mmol})$ was added and the suspension was stirred until the solution became clear. The solution was then cooled to $0^{\circ} \mathrm{C}$ and $10 \mathrm{~b}(500 \mathrm{mg}, 1.9$ mmol, dissolved in $20 \mathrm{ml} \mathrm{MeCN})$ and TMSOTf $(1 \mathrm{ml}, 3.9 \mathrm{mmol})$ were added. After $1 \mathrm{~h}$ at $0^{\circ} \mathrm{C}$ the mixture was allowed to warm to r.t. and the stirring was continued for another $16 \mathrm{~h}$. It was diluted with ethyl acetate and washed with sat. $\mathrm{NaHCO}_{3}$ Purification by FC (ethyl acetate/hexane $4: 1$ ) yielded the desired nucleoside $\mathbf{1 4 a} / \mathbf{b}$ ( 638 $\mathrm{mg}, 1.5 \mathrm{mmol}, 76 \%$ ) in an anomeric ratio of $\alpha / \beta 1.5: 1$ as a white foam. $\mathrm{R}_{\mathrm{f}} 0.26$ (ethyl acetate/hexane 4:1), HR-MS $\left(\mathrm{NSI}^{+}, \mathrm{MeCN}\right)$ for $\mathrm{C}_{22} \mathrm{H}_{23} \mathrm{~N}_{3} \mathrm{O}_{7}$. calc: 442.1609 , found: $442.1617\left(\mathrm{M}+\mathrm{H}^{+}\right),{ }^{1} \mathrm{H}$ NMR $\left(300 \mathrm{MHz}, \mathrm{CDCl}_{3}\right) \delta 8.87(b r, 2 \mathrm{H}), 7.92(m, 4 \mathrm{H}), 7.63$ $7.47(m, 8 \mathrm{H}), 6.10(m 2 \mathrm{H}), 5.20(m, 2 \mathrm{H}), 5.03(d d, 1 \mathrm{H}, J=6.8,3.2), 4.66(d, 1 \mathrm{H}, J=$ 5.7), $3.19(d d, 1 \mathrm{H}, J=14.8,5.4), 2.91(d d, 1 \mathrm{H}, J=15.4,6.5), 2.70(\mathrm{~m}, 3 \mathrm{H}), 2.30(\mathrm{~m}$ $1 \mathrm{H}), 2.25-2.11(\mathrm{~m}, 5 \mathrm{H}), 2.07(\mathrm{~s}, 3 \mathrm{H}), 2.04,2.03(2 s, 6 \mathrm{H}), 1.99(m, 1 \mathrm{H}), 1.93(s, 3 \mathrm{H}) .{ }^{13} \mathrm{C}$ NMR (101 MHz, MeOD) $\delta 172.40,172.25,172.03,171.74,164.98,146.02,145.77$,
$134.66,134.14,134.12,130.47,129.84,129.57,129.17,129.14,123.36,120.19,98.89$ $98.11,92.31,92.07,91.40,90.17,89.95,89.44,88.06,87.65,75.13,61.55,45.90$ $45.44,44.12,43.44,38.32,37.57,21.47,21.30,20.90,20.88,20.86,14.45$

(3'S, 6'S)-1-(2'-Deoxy-3',5'-ethano- $\alpha$ - and - $\beta$-D-ribofuranosyl] thymine $15 \boldsymbol{a} / \boldsymbol{b}$ The nucleoside 12a/b (480 mg, $1.36 \mathrm{mmol}$ ) was dissolved in $0.2 \mathrm{M} \mathrm{NaOH}$ in $5: 4: 1$ $\mathrm{THF} / \mathrm{methanol} / \mathrm{H}_{2} \mathrm{O}(65 \mathrm{ml})$ at $0^{\circ} \mathrm{C}$ : The solution was stirred for one hour at $0^{\circ} \mathrm{C}$ and quenched by the addition of ammonium chloride. The solvents were then evaporated and the remains absorbed on silica gel. Purification by FC (10\% methanol in DCM) yielded compound $\mathbf{1 5 a} / \mathbf{b}(294 \mathrm{mg}, 1.1 \mathrm{mmol}, 81 \%)$ in an anomeric ratio of $\alpha / \beta \sim 1.25: 1$ as a white foam. $\mathrm{R}_{\mathrm{f}} 0.19$ (10\% methanol in DCM), HR-MS ( $\left.\mathrm{NSI}^{+}, \mathrm{MeCN}\right)$ for $\mathrm{C}_{12} \mathrm{H}_{16} \mathrm{~N}_{2} \mathrm{O}_{5}$. Calc. 269.1132, found 268.1141 $\left(\mathrm{M}+\mathrm{H}^{+}\right),{ }^{1} \mathrm{H}$ NMR $(400 \mathrm{MHz}, \mathrm{MeOD}) \delta$ $7.74(s, 1 \mathrm{H}), 7.40(s, 1 \mathrm{H}), 6.10(m, 2 \mathrm{H}), 4.55(d d, 1 \mathrm{H}, J=6.6,1.9), 4.38(m, 1 \mathrm{H}),$, $(m, 1 \mathrm{H}) 4.18(d d, 1 \mathrm{H}, J=6.7,1.0), 2.52(d d, 1 \mathrm{H}, J=14.7,7.1), 2.34(m, 4 \mathrm{H}), 2.14(m$ $\left.1 \mathrm{H}), 2.05(m, 2 \mathrm{H}), \mathrm{H}-\mathrm{C}\left(7^{\prime}\right)\right), 1.90(m, 3 \mathrm{H}), 1.89(m, 3 \mathrm{H}), 1.88(m, 2 \mathrm{H}), 1.80(m, 1 \mathrm{H})$, $1.71(m, 1 \mathrm{H}) .{ }^{13} \mathrm{C}$ NMR $(101 \mathrm{MHz}, \mathrm{MeOD}) \delta 166.55,166.22,152.52,152.23,138.60$ (C-6), 137.07 (C-6), 111.98, 111.06, 91.65, 89.49 88.58, 86.24, 85.50, 84.89, 71.98, $71.69,49.33,47.57,46.94,42.08,41.15,20.84,12.51,12.41$

(3'S, 6'S)-N6-Benzoyl-9-(2'-deoxy-3',5'-ethano- $\alpha$ - and - $\beta$-D-ribofuranosyl] adenine $16 \mathbf{a} / \mathbf{b}$ The nucleosides $13 \mathrm{a} / \mathrm{b}(606 \mathrm{mg}, 1.3 \mathrm{mmol})$ were dissolved in $0.2 \mathrm{M} \mathrm{NaOH}$ in 5:4:1 THF/methanol/ $\mathrm{H}_{2} \mathrm{O}(90 \mathrm{ml})$ at $0^{\circ} \mathrm{C}$ : The solution was stirred for one hour at $0{ }^{\circ} \mathrm{C}$ and quenched by the addition of ammonium chloride. The solvents were then evaporated and the remains absorbed on silica gel. Purification by FC (10\% methanol in DCM) yielded compound $16 \mathrm{a} / \mathrm{b}(437 \mathrm{mg}, 1.14 \mathrm{mmol}, 88 \%)$ in anomeric ratio of $\alpha / \beta \sim 1: 1$ as a white foam. $\mathrm{R}_{\mathrm{f}} 0.2\left(10 \%\right.$ methanol in DCM), HR-MS (NSI$\left.{ }^{+}, \mathrm{MeOH}\right)$ for $\mathrm{C}_{19} \mathrm{H}_{19} \mathrm{~N}_{5} \mathrm{O}_{4}$. calc: 382.1510 , found: $382.1512\left(\mathrm{M}+\mathrm{H}^{+}\right),{ }^{1} \mathrm{H}$ NMR $(300 \mathrm{MHz}, \mathrm{MeOD}) \delta$ $8.76(s, 1 \mathrm{H}), 8.70(2 s, 2 \mathrm{H}), 8.54(s, 1 \mathrm{H}), 8.07(m, 4 \mathrm{H}), 7.67-7.61(m, 2 \mathrm{H}), 7.57-7.52(m$, $4 \mathrm{H}), 6.51(d d, 1 \mathrm{H} J=7.2,1.8), 6.33(d d, 1 \mathrm{H}, J=9.7,5.3), 4.64-4.58(m, 1 \mathrm{H}), 4.49(d, J$ $=5.9), 4.37-4.26(m, 2 \mathrm{H}), 2.91-2.83(m, 2 \mathrm{H}), 2.72(d d, 1 \mathrm{H} J=14.9,7.3), 2.59(d d, 1 \mathrm{H}$, $J=13.5,5.3), 2.48-2.37(m, 2 \mathrm{H}), 2.21-2.07(m, 2 \mathrm{H}), 1.92-1.74(m, 4 \mathrm{H}) .{ }^{13} \mathrm{C}$ NMR $(75$ $\mathrm{MHz}, \mathrm{MeOD}) \delta 153.36,153.18,152.95,151.12,151.08,144.82,144.29,134.95$, $133.88,129.74,129.41,91.51,90.22,86.86,86.06,85.82,85.41,71.74,71.54,47.85$, $47.03,41.50,41.32$

(3'S, 6'S)-N6-Benzoyl-1-(2'-deoxy-3',5'-ethano- $\alpha$ - and - $\beta$-D-ribofuranosyl] cytosine $\mathbf{1 7 a} / \mathbf{b}$ The nucleoside $\mathbf{1 4 a} / \mathbf{b}(316 \mathrm{mg}, 0.72 \mathrm{mmol})$ was dissolved in $0.2 \mathrm{M} \mathrm{NaOH}$ in 5:4:1 THF/methanol $/ \mathrm{H}_{2} \mathrm{O}(50 \mathrm{ml})$ at $0^{\circ} \mathrm{C}$. The solution was stirred for one hour at $0^{\circ} \mathrm{C}$ and quenched by the addition of ammonium chloride. The solvents were then evaporated and the remains absorbed on silica gel. Purification by FC (10\% methanol in DCM) yielded compound $\mathbf{1 7} \mathbf{a} / \mathbf{b}(191 \mathrm{mg}, 0.53 \mathrm{mmol}, 74 \%)$ in an anomeric ratio of $\alpha / \beta \sim 1: 1$ as a white foam. $\mathrm{R}_{\mathrm{f}} 0.36\left(10 \%\right.$ methanol in DCM), HR-MS (NSI $\left.{ }^{+}, \mathrm{MeCN}\right)$ for $\mathrm{C}_{18} \mathrm{H}_{19} \mathrm{~N}_{3} \mathrm{O}_{7}$. calc: 358.1397 , found: $358.1387\left(\mathrm{M}+\mathrm{H}^{+}\right),{ }^{1} \mathrm{H}$ NMR $(300 \mathrm{MHz}, \mathrm{MeOD}) \delta$ $8.26(d, 1 \mathrm{H}, \mathrm{J}=7.5), 8.18(d, 1 \mathrm{H}, \mathrm{J}=7.5), 7.99(m, 2 \mathrm{H}), 7.96(m, 2 \mathrm{H}), 7.63(m, 4 \mathrm{H})$, $7.55(m, 4 \mathrm{H}), 6.10(m, 2 \mathrm{H}), 4.72(d d, 1 \mathrm{H}, \mathrm{J}=7.2,2.1), 4.40-4.28(m, 3 \mathrm{H}), 2.69(d d, 1 \mathrm{H}$, $\mathrm{J}=13.7,5.2), 2.59(d d, 1 \mathrm{H}, \mathrm{J}=14.8,6.7), 2.45(d d, 1 \mathrm{H}, \mathrm{J}=14.8,2.3), 2.38-2.29(m$ $2 \mathrm{H}), 2.23(m, 1 \mathrm{H}), 2.14(m, 1 \mathrm{H}), 1.96-1.85(m, 3 \mathrm{H}), 1.81-1.69(m, 2 \mathrm{H}) .{ }^{13} \mathrm{C}$ NMR $(101$ $\mathrm{MHz}, \mathrm{MeOD}) \delta 164.81,146.56,146.10,145.61,134.74,134.69,134.10,134.04$, $129.83,129.82,129.16,129.11,98.80,97.96,92.69,91.59,90.35,88.28,87.99,87.32$, $85.96,85.89,82.54,80.66,79.66,72.15,71.89,71.53,58.32,57.06,57.01,48.88$ $48.31,46.79,45.89,43.79,42.06,41.63,41.24,18.36$

(3'S, 6'S)-1-(2'-Deoxy-6'-O-(methylsulfonyl)-3'; 5 '-ethano- $\alpha$ - and - $\beta$-D-ribofuranosyl thymine $\mathbf{1 8 a} / \mathbf{b}$ A solution of $\mathbf{1 5} \mathbf{a} / \mathbf{b}(294 \mathrm{mg}, 1.09 \mathrm{mmol})$ was dissolved in pyridine (15 $\mathrm{ml})$ and cooled to $0^{\circ} \mathrm{C}$. $\mathrm{MsCl}(85 \mu 1,1.09 \mathrm{mmol})$ was added and the mixture was stirred at $0^{\circ} \mathrm{C}$ and over night at $4{ }^{\circ} \mathrm{C}$. After quenching by the addition of sat. $\mathrm{NaHCO}_{3}$ and washing with ethyl acetate the combined organic layers were dried over $\mathrm{MgSO}_{4}$ and purified by FC (5\% methanol in DCM) to yield $\mathbf{1 8 a} / \mathbf{b}(250 \mathrm{mg}, 0.72 \mathrm{mmol}, 66 \%)$ in an anomeric ratio of $\alpha / \beta \sim 1.25: 1$ as a white solid. $\mathrm{R}_{\mathrm{f}} 0.45$ (10\% methanol in DCM), HR-MS $\left(\mathrm{NSI}^{+}, \mathrm{MeOH}\right)$ for $\mathrm{C}_{13} \mathrm{H}_{18} \mathrm{~N}_{2} \mathrm{O}_{7} \mathrm{~S}$. Calc. 347.0907, found $347.0902\left(\mathrm{M}+\mathrm{H}^{+}\right),{ }^{1} \mathrm{H} \mathrm{NMR}$ (400 MHz, DMSO) $\delta 11.35(s, 1 \mathrm{H}), 11.27(s, 1 \mathrm{H}), 7.68(s, 1 \mathrm{H}), 7.55(s, 1 \mathrm{H}), 6.08(\mathrm{~m}$, $2 \mathrm{H}), 5.18(\mathrm{~m}, 1 \mathrm{H}), 5.07(\mathrm{~m}, 1 \mathrm{H}), 4.50(d d, 1 \mathrm{H}, J=6.2,2.0), 4.10(d d, 1 \mathrm{H}, J=7.1,2.2)$, $3.22(s, 3 \mathrm{H}), 3.20(s, 3 \mathrm{H}), 2.52(m, 3 \mathrm{H}), 2.20(m, 5 \mathrm{H}), 2.08(m, 2 \mathrm{H}), 1.99(m, 1 \mathrm{H}), 1.90$ $(m, 1 \mathrm{H}), 1.81(m, 3 \mathrm{H}), 1.79(m, 3 \mathrm{H}) .{ }^{13} \mathrm{C}$ NMR (101 MHz, DMSO) $\delta 163.80,163.61$, 150.45, 150.43, 136.44, 135.96, 109.70, 109.11, 88.09 (C4'), 86.61 (C4'), 85.51 (C1'), 84.10 (C1'), 83.45, 83.11, 80.49, 80.23, 45.40, 45.21, 45.05, 44.06, 38.32, 37.70, 37.55, $37.42,12.2,12.11$

(3'S, 6'S)-N6-Benzoyl-9-(2'-deoxy-, 6'-O-(methylsulfonyl)-3',5'-ethano- $\alpha$ - and $-\beta-D$ ribofuranosyl] adenine $(19 a, 19 b)$ A solution of $16 \mathbf{a} / \mathbf{b}(153 \mathrm{mg}, 0.4 \mathrm{mmol})$ was dissolved in pyridine $(6 \mathrm{ml})$ and cooled to $0^{\circ} \mathrm{C}$. $\mathrm{MsCl}(0.03 \mathrm{ml}, 0.4 \mathrm{mmol})$ was added and the mixture was stirred for $2 \mathrm{~h}$ at $\mathrm{rt}$. Silica was then added and the pyridine was evaporated and shortly high vac dried. FC (7\% methanol in DCM) yielded the corresponding anomers 19a (105 mg. $0.23 \mathrm{mmol}, 57 \%)$ and $19 \mathrm{~b}(73 \mathrm{mg}, 0.16 \mathrm{mmol}$, $39 \%)$ as white foams. Analytical data for 19a: $\mathrm{R}_{\mathrm{f}} 0.5$ (10\% methanol in DCM), HR-MS $\left(\mathrm{NSI}^{+}, \mathrm{MeOH}\right)$ for $\mathrm{C}_{20} \mathrm{H}_{21} \mathrm{~N}_{5} \mathrm{O}_{6} \mathrm{~S}$. calc: 460.1285 , found: $460.1272\left(\mathrm{M}+\mathrm{H}^{+}\right),{ }^{1} \mathrm{H} \mathrm{NMR}$ (400 MHz, MeOD) $\delta 8.74(2 s, 2 \mathrm{H}), 8.09(m, 2 \mathrm{H}), 7.65(m, 1 \mathrm{H}), 7.57(m, 2 \mathrm{H}), 6.56(d d$, $1 \mathrm{H}, J=7.1,2.6), 5.21-5.14(m, 1 \mathrm{H}), 4.59(d d, 1 \mathrm{H}, J=6.3,1.5), 3.12(s, 3 \mathrm{H}), 2.92(d d$, 
$1 \mathrm{H}, J=14.9,2.6), 2.84(d d, 1 \mathrm{H}, J=14.8,7.2), 2.67(d d d, 1 \mathrm{H}, J=13.4,6.5,1.3), 2.40$ $2.35(m, 1 \mathrm{H}), 2.26-2.14(m, 2 \mathrm{H}) .{ }^{13} \mathrm{C}$ NMR $(101 \mathrm{MHz}, \mathrm{MeOD}) \delta 168.16,153.11$, $151.22,144.78,138.41,134.99,133.92,129.78,129.43,125.29,90.39,86.96,85.87$, 81.13, 47.38, 47.26, 39.44, 38.11. Analytical data for $\mathbf{1 9 b} \mathrm{R}_{\mathrm{f}} 0.4(10 \%$ methanol in DCM), HR-MS ( $\mathrm{NSI}^{+}, \mathrm{MeOH}$ ) for $\mathrm{C}_{20} \mathrm{H}_{21} \mathrm{~N}_{5} \mathrm{O}_{6} \mathrm{~S}$. calc: 460.1285 , found: 460.1273 (M $\left.\mathrm{H}^{+}\right){ }^{1} \mathrm{H}$ NMR $(400 \mathrm{MHz}, \mathrm{MeOD}) \delta 8.73(s, 1 \mathrm{H}), 8.54(s, 1 \mathrm{H}), 8.08(m, 2 \mathrm{H}), 7.63(m$, $1 \mathrm{H}), 7.55(\mathrm{~m}, 2 \mathrm{H}), 6.37(d d, 1 \mathrm{H}, J=9.3,5.9), 5.66-5.58(m, 1 \mathrm{H}), 4.38(d d, 1 \mathrm{H}, J=6.9$, $1.8), 3.13(s, 3 \mathrm{H}), 3.05(m, 1 \mathrm{H}), 2.75(d d d, 1 \mathrm{H}, J=13.0,6.2,1.3), 2.63(d d, 1 \mathrm{H}, J=$ $13.8,5.9), 2.43(m, 1 \mathrm{H}), 2.20(d d d, 1 \mathrm{H}, J=14.1,8.5,7.0), 2.10(d d, 1 \mathrm{H}, J=13.0,8.9)$. ${ }^{13} \mathrm{C}$ NMR (101 MHz, MeOD) $\delta 168.15,153.20,151.22,144.75,138.43,134.96,133.89$, $129.79,129.75,129.41,125.56,89.26,86.34,85.54,81.11,46.85,46.41,39.32,38.16$, 18.39

(3'S, 6'S)-N6-Benzoyl-1-(2'-deoxy-, 6'-O-(methylsulfonyl)-3',5'-ethano- $\alpha$ - and $-\beta$ - $D$ ribofuranosyl] cytosine $20 \mathbf{a} / \mathbf{b}$ A solution of $\mathbf{1 7} \mathbf{a} / \mathbf{b}(415 \mathrm{mg}, 1.16 \mathrm{mmol})$ in pyridine (16 $\mathrm{ml})$ was cooled to $0^{\circ} \mathrm{C}$ and $\mathrm{MsCl}(90 \mu \mathrm{l}, 1.16 \mathrm{mmol})$ was added. The mixture was stirre overnight at $4{ }^{\circ} \mathrm{C}$. Sat. $\mathrm{NaHCO}_{3}$ was added and the aqueous phase was extracted with ethyl acetate. The crude product $\mathbf{2 0} \mathbf{a} / \mathbf{b}$ precipitated in the organic phase and was used in the next experiment without further purification. $\mathrm{R}_{\mathrm{f}} 0.49$ (10\% methanol in DCM), HRMS (NSI+, THF) for $\mathrm{C}_{19} \mathrm{H}_{21} \mathrm{~N}_{3} \mathrm{O}_{7}$ S. Calc. 436.1173, found 436.1172 $\left(\mathrm{M}+\mathrm{H}^{+}{ }^{1}{ }^{1} \mathrm{H}\right.$ NMR (400 MHz, DMSO) $\delta 11.21(\mathrm{br}, 2 \mathrm{H}), 8.23(\mathrm{~m}, 2 \mathrm{H}), 8.00(\mathrm{~m}, 4 \mathrm{H}), 7.62(\mathrm{~m}, 2 \mathrm{H}), 7.51(\mathrm{~m}$ $4 \mathrm{H}), 7.37(m, 2 \mathrm{H}), 6.11(d d, 1 \mathrm{H}, J=9.3,5.1), 6.04(d d, 1 \mathrm{H}, J=6.8,2.7), 5.68(s, 1 \mathrm{H})$ $5.53(s, 1 \mathrm{H}), 5.20(m, 1 \mathrm{H}), 5.10(m, 1 \mathrm{H}), 4.67(d d, 1 \mathrm{H}, J=6.9,2.3), 4.23(d d, 1 \mathrm{H}, J=$ $7.1,1.9), 3.23(s, 3 \mathrm{H}), 3.21(\mathrm{~s}, 3 \mathrm{H}), 2.63(d d, 1 \mathrm{H}, J=14.5,6.9), 2.47(\mathrm{~m}, 2 \mathrm{H}), 2.31(\mathrm{~m}$ $2 \mathrm{H}), 2.24(m, 2 \mathrm{H}), 2.14(m, 2 \mathrm{H}), 2.06(m, 1 \mathrm{H}) 1.96(m, 2 \mathrm{H}) .{ }^{13} \mathrm{C}$ NMR $(101 \mathrm{MHz}$ DMSO) $\delta 162.99,145.29,133.20,132.74,132.65,128.45,128.40,95.63,89.25,88.90$ $87.29,85.21,83.76,80.22,79.86,46.10,45.99,45.16,45.10,38.38,37.71,37.40$, 21.01

(3'S, 6'S)-1-(3'-O-Acetyl-2'-deoxy-6'-O-(methylsulfonyl)-3 ',5'-ethano- $\alpha$ - and $-\beta-D-$ ribofuranosyl] thymine $\mathbf{2 1 a} / \mathbf{b}$ A solution of $\mathbf{1 8 a} / \mathbf{b}(250 \mathrm{mg}, 0.72 \mathrm{mmol})$ in pyridine (7) $\mathrm{ml}$ ) was cooled to $0^{\circ} \mathrm{C}$ and DMAP $(9 \mathrm{mg}, 0.07 \mathrm{mmol})$ and $\mathrm{Ac}_{2} \mathrm{O}(0.08 \mathrm{ml}, 0.8 \mathrm{mmol})$ were added. The mixture was stirred over night at r.t. and, after cooling to $0^{\circ} \mathrm{C}$, carefully quenched and washed with sat. $\mathrm{NaHCO}_{3}$. The aqueous layers were extracted with DCM. The combined organic layers were dried over $\mathrm{MgSO}_{4}$ and evaporated. FC (3\% methanol in DCM) yielded $\mathbf{2 1 a} / \mathbf{b}(218 \mathrm{mg}, 0.56 \mathrm{mmol}, 78 \%)$ an anomeric ratio of $\alpha / \beta \sim 1.25: 1$ as a white foam. $\mathrm{R}_{\mathrm{f}} 0.49(10 \%$ methanol in DCM), NSI pos $(\mathrm{MeCN})$ for $\mathrm{C}_{15} \mathrm{H}_{20} \mathrm{~N}_{2} \mathrm{O}_{8}$ S. Calc. 389.1013, found $389.1019\left(\mathrm{M}+\mathrm{H}^{+}\right){ }^{1} \mathrm{H} \mathrm{NMR}\left(400 \mathrm{MHz}, \mathrm{CDCl}_{3}\right) \delta$ $7.24(m, 1 \mathrm{H}), 7.06(m, 1 \mathrm{H}), 6.11(t, 1 \mathrm{H}, J=6.2), 6.03(d d, 1 \mathrm{H}, J=9.2,5.6), 5.24-5.15$ $(m, 2 \mathrm{H}), 4.95(d d, 1 \mathrm{H}, J=6.2,3.3), 4.58(d d, 1 \mathrm{H}, J=6.4,1.4), 3.05,3.03(2 s, 6 \mathrm{H}), 2.92$ $(d d, 1 \mathrm{H}, J=14.8,6.6), 2.84(m, 2 \mathrm{H}), 2.68(d d, 1 \mathrm{H}, J=15.3,6.0), 2.54(m, 2 \mathrm{H}), 2.48$ $2.29(m, 5 \mathrm{H}), 2.14(m, 1 \mathrm{H}), 2.09,2.07(2 s, 6 \mathrm{H}), 1.97(m, 3 \mathrm{H}), 1.96(m, 3 \mathrm{H}) .{ }^{13} \mathrm{C}$ NMR $\left(101 \mathrm{MHz}, \mathrm{CDCl}_{3}\right) \delta 170.02,163.14,162.93,149.91,149.81,134.92,134.66,111.82$ $111.20,90.48,89.56,86.93,86.34,84.73,84.62,79.91,78.92,77.33,77.01,76.69$ $44.27,43.96,43.89,43.79,38.55,38.46,37.24,21.05,12.68,12.63$.

(3'S, 6'S)-N6-Acetyl-9-[3'-O-acetyl-2'-deoxy-6'-O-(methylsulfonyl)-3',5'-ethano- $\beta$ - $D$ ribofuranosyl] -N6-benzoyladenine $22 b$ A solution of $19 b(195 \mathrm{mg}, 0.42 \mathrm{mmol})$ in pyridine $(12 \mathrm{ml})$ was cooled to $0^{\circ} \mathrm{C}$ and DMAP $(5 \mathrm{mg}, 42 \mu \mathrm{mol})$ and $\mathrm{Ac}_{2} \mathrm{O}(0.12 \mathrm{ml}, 1.3$ mmol) were added. The mixture was stirred for $16 \mathrm{~h}$ at r.t. and, after cooling to $0^{\circ} \mathrm{C}$, carefully quenched and washed with sat. $\mathrm{NaHCO}_{3}$. The aqueous layers were extracted with DCM. The combined organic layers were dried over $\mathrm{MgSO}_{4}$ and evaporated. FC (5\% methanol in DCM) yielded $22 \mathbf{b}(192 \mathrm{mg}, 0.38 \mathrm{mmol}, 91 \%)$ as a white foam. $\mathrm{R}_{\mathrm{f}} 0.8$ (10\% methanol in DCM), HR-MS (NSI ${ }^{+}$, EtOAc) for $\mathrm{C}_{22} \mathrm{H}_{23} \mathrm{~N}_{5} \mathrm{O}_{4} \mathrm{~S}$. calc: 502.1391 , found: $502.11385\left(\mathrm{M}+\mathrm{H}^{+}\right),{ }^{1} \mathrm{H}$ NMR $\left(400 \mathrm{MHz}, \mathrm{CDCl}_{3}\right) \delta 8.69(s, 1 \mathrm{H}), 8.31(s, 1 \mathrm{H})$ $7.71(m, 2 \mathrm{H}), 7.42(m, 1 \mathrm{H}), 7.32(m, 2 \mathrm{H}), 6.42(d d, 1 \mathrm{H}, \mathrm{J}=6.9,2.9), 5.18(m, 1 \mathrm{H}) 4.90$ $(d d, 1 \mathrm{H}, \mathrm{J}=6.1,1.7), 3.41(\mathrm{~m}, 1 \mathrm{H}), 3.03(\mathrm{~s}, 3 \mathrm{H}), 2.89(\mathrm{~m}, 2 \mathrm{H}), 2.44(\mathrm{~m}, 2 \mathrm{H}), 2.34(\mathrm{~m}$ $1 \mathrm{H}), 2.09(s, 3 \mathrm{H}) .{ }^{13} \mathrm{C}$ NMR $\left(101 \mathrm{MHz}, \mathrm{CDCl}_{3}\right) \delta 175.38,172.86,172.05,170.24$ $152.94,152.53,152.43,151.16,134.41,133.07,129.44,129.01,128.78,90.34,87.23$, $79.21,44.41,43.96,38.65,37.68,25.61,21.37$

(3'S, 6'S)-N6-Acetyl-1-[3'-O-acetyl-2'-deoxy-6'-O-(methylsulfonyl)-3 ', 5'-ethano- $\alpha$ and $\beta$-D-ribofuranosyl] -N6-benzoylcytosine $23 \mathbf{a} / \mathbf{b}$ A solution of $\mathbf{2 0 a} / \mathbf{b}(769 \mathrm{mg}, 1.76$ mmol) in pyridine $(35 \mathrm{ml})$ was cooled to $0^{\circ} \mathrm{C}$ and DMAP $(22 \mathrm{mg}, 0.18 \mathrm{mmol})$ and $\mathrm{Ac}_{2} \mathrm{O}$ $(0.5 \mathrm{ml}, 5.28 \mathrm{mmol})$ were added. The mixture was stirred for $20 \mathrm{~h}$ at $\mathrm{rt}$ and, after cooling to $0^{\circ} \mathrm{C}$, carefully quenched and washed with sat. $\mathrm{NaHCO}_{3}$. The aqueous layers were extracted with DCM. The combined organic layers were dried over $\mathrm{MgSO}_{4}$ and evaporated. FC (5\% methanol in DCM) yielded $23 \mathrm{a} / \mathbf{b}(628 \mathrm{mg}, 1.3 \mathrm{mmol}, 75 \%$ ove two steps) in an anomeric ratio of $\alpha / \beta \sim 2: 1$ as a white foam. $\mathrm{R}_{\mathrm{f}} 0.9(10 \%$ methanol in DCM), HR-MS (NSI ${ }^{+}$, EtOAc) for $\mathrm{C}_{2} 1 \mathrm{H}_{23} \mathrm{~N}_{3} \mathrm{O}_{8} \mathrm{~S}$. calc: 478.1279 , found: 478.1268 (M + $\left.\mathrm{H}^{+}\right),{ }^{1} \mathrm{H}$ NMR $\left(400 \mathrm{MHz}, \mathrm{CDCl}_{3}\right) \delta 7.93(m, 6 \mathrm{H}), 7.61(m, 4 \mathrm{H}), 7.55(m, 4 \mathrm{H}), 6.10(d d$ $1 \mathrm{H}, J=6.4,4.1), 6.04(d d, 1 \mathrm{H}, J=8.5,5.6), 5.19(m, 2 \mathrm{H}), 5.04(d d, 1 \mathrm{H}, J=5.9,3.7)$, $4.69(\mathrm{~d}, 1 \mathrm{H}), 3.15(m, 1 \mathrm{H}), 3.04(\mathrm{~s}, 3 \mathrm{H}), 3.03(\mathrm{~s}, 3 \mathrm{H}), 2.99(\mathrm{~m}, 1 \mathrm{H}), 2.83-2.67(\mathrm{~m}, 3 \mathrm{H})$ $2.50(m, 2 \mathrm{H}), 2.35(m, 4 \mathrm{H}), 2.08(m, 6 \mathrm{H}), 2.04(m, 1 \mathrm{H}) .{ }^{13} \mathrm{C} \mathrm{NMR}\left(101 \mathrm{MHz}, \mathrm{CDCl}_{3}\right) \delta$ $176.17,170.32,170.09,163.25,163.18,154.73,149.28,144.01,136.97,133.47$ $132.99,129.09,128.19,97.45,96.72,90.54,90.08,89.53\left(\mathrm{C}\left(1^{\prime}\right)\right), 88.09,86.89,85.77$, $79.77,79.31,45.55,45.11,44.25,43.74,38.64,38.61,38.58,37.66,29.87,29.53$ $21.66,21.53,21.15$
(3'S, 6'R)-1-(3', 6'-Di-O-acetyl-2'-deoxy-3',5'-ethano- $\alpha$ - and - $\beta$-D-ribofuranosyl] thymine $24 \mathbf{a} / \mathbf{b}$ A solution containing $21 \mathrm{a} / \mathbf{b}(301 \mathrm{mg}, 0.77 \mathrm{mmol})$ and $\mathrm{CsOAc}(2.1 \mathrm{~g}$, $10.7 \mathrm{mmol})$ in DMSO $(15 \mathrm{ml})$ was heated to $85^{\circ} \mathrm{C}$ and stirred for $16 \mathrm{~h}$. After cooling to r.t. the mixture was diluted with ethyl acetate and washed with sat. $\mathrm{NaHCO}_{3}$. The combined organic layers were washed with $\mathrm{H}_{2} \mathrm{O}$ and dried over $\mathrm{MgSO}_{4}$. Via FC $(5 \%$ methanol in DCM) $24 \mathrm{a} / \mathbf{b}(254 \mathrm{mg}, 0.72 \mathrm{mmol}, 93 \%$ ) an anomeric ratio of $\alpha / \beta \sim 1.25: 1$ was obtained as a white foam. $\mathrm{R}_{\mathrm{f}} 0.88\left(10 \%\right.$ methanol in DCM), HR-MS (NSI $\left.{ }^{+}, \mathrm{MeOH}\right)$ for $\mathrm{C}_{16} \mathrm{H}_{20} \mathrm{~N}_{2} \mathrm{O}_{7}$. Calc. 353.1343, found $353.1341\left(\mathrm{M}+\mathrm{H}^{+}\right){ }^{1} \mathrm{H}$ NMR (400 MHz, $\left.\mathrm{CDCl}_{3}\right)$ $\delta 7.36(m, 1 \mathrm{H}), 7.30(m, 1 \mathrm{H}),, 6.41(t, 1 \mathrm{H}, J=6.4), 6.20(d d, 1 \mathrm{H}, J=9.7,5.2), 5.43(m$ $1 \mathrm{H}), 5.27(m, 1 \mathrm{H}), 4.94(d d, 1 \mathrm{H}, J=6.8,1.4), 4.62(d, 1 \mathrm{H}, J=6.8), 2.98(m, 1 \mathrm{H}),$, $(d d, 1 \mathrm{H}, J=14.3,5.2), 2.55(m, 2 \mathrm{H}), 2.43(m, 1 \mathrm{H}), 2.38(m, 3 \mathrm{H}), 2.30(m, 1 \mathrm{H}), 2.15(m$ $2 \mathrm{H}), 2.10,2.09(2 s, 6 \mathrm{H}), 2.06-2.01(m, 1 \mathrm{H}), 2.04,2.03(2 s, 6 \mathrm{H}), 1.95(m, 3 \mathrm{H}), 1.93(\mathrm{~m}$ $3 \mathrm{H}) .{ }^{13} \mathrm{C}$ NMR $\left(101 \mathrm{MHz}, \mathrm{CDCl}_{3}\right) \delta 170.51,170.27,169.74,163.97,163.70,150.64$ $150.52,135.17,134.65,111.64,111.37,93.65,93.53,88.38,87.53,86.04,83.88,77.43$, $77.28,75.10,45.15,45.04,44.65,44.36,42.85,38.75,37.50,21.76,21.64,21.40$ $12.86,12.81$.

(3 'S, 6'R)-N6-Benzoyl-9-(3',6'-di-O-acetyl-2'-deoxy-3 ',5'-ethano- $\beta$-D-ribofuranosyl] adenine $25 \boldsymbol{b}$ A solution containing 22b $(219 \mathrm{mg}, 0.41 \mathrm{mmol})$ and $\mathrm{CsOAc}(1.1 \mathrm{~g}, 6$ $\mathrm{mmol}$ ) in DMSO (8 ml) was heated to $85^{\circ} \mathrm{C}$ and stirred for $16 \mathrm{~h}$. After cooling to r.t. the mixture was diluted with ethyl acetate and washed with sat. $\mathrm{NaHCO}_{3}$. The combined organic layers were washed with $\mathrm{H}_{2} \mathrm{O}$ and dried over $\mathrm{MgSO}_{4}$. FC purification $(5 \%$ methanol in DCM) yielded $\mathbf{3 2 5 b}(155 \mathrm{mg}, 0.33 \mathrm{mmol}, 81 \%)$ as a white foam. $\mathrm{R}_{\mathrm{f}} 0.75$ (10\% methanol in DCM), HR-MS $\left(\mathrm{NSI}^{+}, \mathrm{MeCN}\right)$ for $\mathrm{C}_{23} \mathrm{H}_{23} \mathrm{~N}_{5} \mathrm{O}_{6}$. calc: 466.1721 , found: $466.1727\left(\mathrm{M}+\mathrm{H}^{+}\right),{ }^{1} \mathrm{H}$ NMR $\left(400 \mathrm{MHz}, \mathrm{CDCl}_{3}\right) \delta 9.11(b r, 1 \mathrm{H}), 8.77(s, 1 \mathrm{H})$, $8.28(s, 1 \mathrm{H}), 8.03(\mathrm{~m}, 2 \mathrm{H}), 7.60(\mathrm{~m}, 1 \mathrm{H}), 7.52(\mathrm{~m}, 2 \mathrm{H}), 6.61(d d, 1 \mathrm{H}, J=6.8,3.1), 5.35$ $(m, 1 \mathrm{H}), 4.96(d, 1 \mathrm{H}), 3.33(\mathrm{~m}, 1 \mathrm{H}), 3.14(\mathrm{~m}, 1 \mathrm{H}), 2.40(\mathrm{~m}, 4 \mathrm{H}), 2.11(\mathrm{~s}, 3 \mathrm{H}), 1.96(s$, $3 \mathrm{H}) .{ }^{13} \mathrm{C}$ NMR $\left(101 \mathrm{MHz}, \mathrm{CDCl}_{3}\right) \delta 170.38,170.30,152.85,141.23,141.15,136.16$ $133.04,130.49,129.06,128.15,94.17,89.59,86.63,86.10,85.24,76.29,45.24,44.58$, $38.61,37.99,29.90,21.58,21.48$.

(3'S, 6'R)-N6-Benzoyl-1-(3', 6'-Di-O-acetyl-2'-deoxy-3',5'-ethano- $\alpha$ - and $-\beta$-D ribofuranosyl] cytosine 26a/b A solution containing $\mathbf{2 3 a} / \mathbf{b}(523 \mathrm{mg}, 1.09 \mathrm{mmol})$ and CsOAc $(2.9 \mathrm{~g}, 15.1 \mathrm{mmol})$ in DMSO $(20 \mathrm{ml})$ was heated to $85^{\circ} \mathrm{C}$ and stirred for $16 \mathrm{~h}$. After cooling to r.t. the mixture was diluted with ethyl acetate and washed with sat. $\mathrm{NaHCO}_{3}$. The combined organic layers were washed with $\mathrm{H}_{2} \mathrm{O}$ and dried over $\mathrm{MgSO}_{4}$. The crude product $\mathbf{2 6 a} / \mathbf{b}$ was used for the following step without purification. $\mathrm{R}_{\mathrm{f}} 0.82$ (10\% methanol in DCM), HR-MS (NSI ${ }^{+}$, EtOAc) for $\mathrm{C}_{22} \mathrm{H}_{23} \mathrm{~N}_{3} \mathrm{O}_{7}$. calc: 442.1609 , found: $442.1601\left(\mathrm{M}+\mathrm{H}^{+}\right)$

(3'S, 6'R)-1-(2'-Deoxy-3',5'-ethano- $\alpha$ - and $-\beta$-D-ribofuranosyl] thymine 27a/b The nucleoside $\mathbf{2 4 a} / \mathbf{b}(254 \mathrm{mg}, 0.72 \mathrm{mmol})$ was dissolved in $0.2 \mathrm{M} \mathrm{NaOH}$ in $5: 4: 1$ $\mathrm{THF} / \mathrm{methanol} / \mathrm{H}_{2} \mathrm{O}(40 \mathrm{ml})$ at $0{ }^{\circ} \mathrm{C}$ : The solution was stirred for one hour at $0^{\circ} \mathrm{C}$ and quenched by the addition of ammonium chloride. The solvents were then evaporated and the remains absorbed on silica gel. Purification by FC (10\% methanol in DCM) yielded compound $\mathbf{2 7} \mathbf{a} / \mathbf{b}(123 \mathrm{mg}, 0.45 \mathrm{mmol}, 64 \%)$ in anomeric ratio of $\alpha / \beta \sim 1.25: 1$ as a white foam. $\mathrm{R}_{\mathrm{f}} 0.2$ (10\% methanol in DCM), HR-MS (NSI $\left.{ }^{+}, \mathrm{MeOH}\right)$ for $\mathrm{C}_{12} \mathrm{H}_{16} \mathrm{~N}_{2} \mathrm{O}_{5}$. Calc. 268.0951, found $268.0955\left(\mathrm{M}^{+}\right),{ }^{1} \mathrm{H}$ NMR (400 MHz, DMSO) $\delta 11.25(\mathrm{br}, 2 \mathrm{H})$, $7.76(s, 1 \mathrm{H}), 7.66(s, 1 \mathrm{H}), 6.20(m, 2 \mathrm{H}), 5.31(s, 1 \mathrm{H}), 5.26(s, 1 \mathrm{H}), 4.94(\mathrm{~d}, 1 \mathrm{H}, J=2.7)$, $4.71(\mathrm{~d}, 1 \mathrm{H}, J=3.8), 4.39(d d, 1 \mathrm{H}, J=7.1,3.0), 4.31(m, 1 \mathrm{H}), 4.23(\mathrm{~m}, 1 \mathrm{H}), 4.08(\mathrm{~m}$, $1 \mathrm{H}), 2.62(d d, 1 \mathrm{H}, J=13.7,6.9), 2.31(m, 1 \mathrm{H}), 2.22(m, 1 \mathrm{H}), 2.15(m, 1 \mathrm{H}), 2.09(m$, $1 \mathrm{H}), 2.02(\mathrm{~m}, 2 \mathrm{H}) 1.95(\mathrm{~m}, 1 \mathrm{H}), 1.85(\mathrm{~m}, 1 \mathrm{H}), 1.80(\mathrm{~m}, 3 \mathrm{H}), 1.76(\mathrm{~m}, 3 \mathrm{H}), 1.77(\mathrm{~m}, 2 \mathrm{H})$, $1.55(m, 1 \mathrm{H}) .{ }^{13} \mathrm{C}$ NMR $(101 \mathrm{MHz}, \mathrm{DMSO}) \delta 163.79,163.63,150.40,150.36,136.50$, $109.57,109.13,90.11,89.98,86.81,86.10,85.59,83.66,72.36,70.90,48.33,47.92$, $46.80,46.02,41.32,40.66,12.34,12.25$.

(3'S, 6'R)-N6-Benzoyl-9-(2'-deoxy-3',5'-ethano- $\beta$ - $D$-ribofuranosyl] adenine $28 \boldsymbol{b}$ The nucleoside 25b (115 mg, $0.25 \mathrm{mmol})$ was dissolved in $0.2 \mathrm{M} \mathrm{NaOH}$ in $5: 4: 1$ $\mathrm{THF} / \mathrm{methanol} / \mathrm{H}_{2} \mathrm{O}(17 \mathrm{ml})$ at $0^{\circ} \mathrm{C}$ : The solution was stirred for one hour at $0^{\circ} \mathrm{C}$ and quenched by the addition of ammonium chloride. The solvents were then evaporated and the remains absorbed on silica gel. Purification by FC (10\% methanol in DCM) yielded compound $\mathbf{2 8 b}(80 \mathrm{mg}, 0.21 \mathrm{mmol}, 84 \%)$ as a white foam. $\mathrm{R}_{\mathrm{f}} 0.3(10 \%$ methanol in DCM), HR-MS ( $\left.\mathrm{NSI}^{+}, \mathrm{MeOH}\right)$ for $\mathrm{C}_{19} \mathrm{H}_{19} \mathrm{~N}_{5} \mathrm{O}_{4}$. calc: 382.1510 , found: $382.1505\left(\mathrm{M}+\mathrm{H}^{+}\right),{ }^{1} \mathrm{H}$ NMR $(300 \mathrm{MHz}, \mathrm{MeOD}) \delta 8.71(s, 1 \mathrm{H}), 8.65(s, 1 \mathrm{H}), 8.09(\mathrm{~m}$, $2 \mathrm{H}), 7.65(\mathrm{~m}, 1 \mathrm{H}), 7.55(\mathrm{~m}, 1 \mathrm{H}), 6.55(d d, 1 \mathrm{H}, J=9.3,5.9), 4.50(\mathrm{~m}, 1 \mathrm{H}), 4.38(d d, J=$ $6.9,1.4,1 \mathrm{H}), 3.01(d d, 1 \mathrm{H}, J=13.5,9.4), 2.70(d d, 1 \mathrm{H}, J=13.6,5.9), 2.33-2.24(m$, $2 \mathrm{H}), 2.03(\mathrm{~m}, 2 \mathrm{H}) .{ }^{13} \mathrm{C}$ NMR $(75 \mathrm{MHz}, \mathrm{MeOD}) \delta 153.22,153.09,151.14,144.27$, $134.98,133.90,129.76,129.42,125.05,92.42,88.68,85.90,74.93,54.79,49.46,41.83$.

(3'S, 6'R)-N6-Benzoyl-1-(2'-deoxy-3',5'-ethano- $\alpha$ - and - $\beta$-D-ribofuranosyl] cytosine $29 a / b$ The nucleoside $26 \mathrm{a} / \mathbf{b}(386 \mathrm{mg}, 0.87 \mathrm{mmol})$ was dissolved in $0.2 \mathrm{M} \mathrm{NaOH}$ in 5:4:1 THF/methanol/ $\mathrm{H}_{2} \mathrm{O}(50 \mathrm{ml})$ at $0^{\circ} \mathrm{C}$ : The solution was stirred for one hour at $0^{\circ} \mathrm{C}$ and quenched by the addition of ammonium chloride. The solvents were then evaporated and the remains absorbed on silica gel. Purification by FC (5\% methanol in DCM) yielded compound $29 \mathrm{a} / \mathbf{b}(183 \mathrm{mg}, 0.51 \mathrm{mmol}, 59 \%$ over two steps) in an anomeric ratio of $\alpha / \beta \sim 2: 1$ as a white foam. $\mathrm{R}_{\mathrm{f}} 0.43$ (10\% methanol in DCM), HR-MS ( $\mathrm{NSI}^{+}, \mathrm{MeOH}$ ) for $\mathrm{C}_{18} \mathrm{H}_{19} \mathrm{~N}_{3} \mathrm{O}_{5}$. calc: 380.1217 , found: $380.1220\left(\mathrm{M}+\mathrm{Na}^{+}\right),{ }^{1} \mathrm{H} \mathrm{NMR}$ $(400 \mathrm{MHz}, \mathrm{MeOD}) \delta 8.46(d, 1 \mathrm{H}, J=7.5), 8.28(d, 1 \mathrm{H}, J=7.5), 7.98(m, 4 \mathrm{H}), 7.63(m$, 
$4 \mathrm{H}), 7.54(\mathrm{~m}, 4 \mathrm{H}), 6.33(d d, 1 \mathrm{H}, J=8.9,5.8), 6.21(d d, 1 \mathrm{H}, J=6.8,3.2), 4.68(d d, 1 \mathrm{H}$, $J=7.2,3.1), 4.49(m, 1 \mathrm{H}), 4.43(m, 1 \mathrm{H}), 4.35(d, 1 \mathrm{H}), 3.03(d d, 1 \mathrm{H}, \mathrm{J}=14.4,6.8), 2.67$ $(d d, 1 \mathrm{H}, J=13.6,5.8), 2.37(m, 3 \mathrm{H}), 2.24(m, 1 \mathrm{H}), 2.15(m, 1 \mathrm{H}), 2.09(m, 2 \mathrm{H}), 2.04(m$ $1 \mathrm{H}), 1.94(m, 1 \mathrm{H}), 1.85(m, 1 \mathrm{H}) .{ }^{13} \mathrm{C}$ NMR $(101 \mathrm{MHz}, \mathrm{MeOD}) \delta 169.13,164.79$ $157.92,146.88,146.56,134.76,134.72,134.10,134.06,129.83,129.17,129.13,98.76$, $98.06,93.64,92.52,92.07,88.92,88.10,87.97,74.88,73.43,50.01,48.88,42.27$, 41.63

(3'S, 6'R)-1-\{2'-Deoxy-6'-O-[(4,4'-dimethoxytriphenyl)methyl $]-3$ ', 5 '-ethano- $\alpha$ - and $-\beta$ D-ribofuranosyl $\}$ thymine $(\mathbf{3 0 a}, \mathbf{3 0 b})$ To a solution of nucleoside $\mathbf{2 7} \mathbf{a} / \mathbf{b}(456 \mathrm{mg}, 1.7$ $\mathrm{mmol})$ in pyridine $(8 \mathrm{ml})$ was added DMT-Cl $(1.7 \mathrm{~g} 5.1 \mathrm{mmol})$ in three portions and was stirred for $24 \mathrm{~h}$ at r.t. The solution was then diluted with ethyl acetate, washed with sat. $\mathrm{NaHCO}_{3}$ and dried over $\mathrm{MgSO}_{4}$. Purification by $\mathrm{FC}(2.5 \%$ methanol in DCM $)$ yielded the corresponding anomers $\alpha$ and $\beta$, 30a (470 $\mathrm{mg}, 0.82 \mathrm{mmol}, 48 \%$ ) and 30b (384 mg, $0.67 \mathrm{mmol}, 40 \%$ ) resp., as pale yellow foams. Analytical data of 30: $\mathrm{R}_{\mathrm{f}} 0.23$ (3\% methanol in DCM), HR-MS (NSI ${ }^{+}, \mathrm{MeCN}$ ) for $\mathrm{C}_{33} \mathrm{H}_{34} \mathrm{~N}_{2} \mathrm{O}_{7}$. Calc. 593.2258, found $593.2250\left(\mathrm{M}+\mathrm{Na}^{+}\right),{ }^{1} \mathrm{H}$ NMR $\left(400 \mathrm{MHz}, \mathrm{CDCl}_{3}\right) \delta 7.47(m, 2 \mathrm{H}), 7.35(m, 4 \mathrm{H}), 7.29$ $(m, 2 \mathrm{H}), 7.22(m, 2 \mathrm{H}), 6.83(m, 4 \mathrm{H}), 5.95(d d, 1 \mathrm{H}, J=7.8,3.7), 4.40(d d, 1 \mathrm{H}, J=7.0$ $3.1), 4.24(m, 1 \mathrm{H}), 3.79(s, 6 \mathrm{H}), 2.89(d d, 1 \mathrm{H}, J=14.5,7.8), 2.30(d d, 1 \mathrm{H}, J=14.5$ 3.7), $1.95(m, 1 \mathrm{H}), 1.91(m, 3 \mathrm{H}), 1.67(m, 1 \mathrm{H}), 1.53(m, 2 \mathrm{H}) .{ }^{13} \mathrm{C}$ NMR $(101 \mathrm{MHz}$, $\left.\mathrm{CDCl}_{3}\right) \delta 163.87,158.81,150.59,145.86,138.45,137.10,136.98,130.28,130.25$, $128.28,128.16,127.04,113.49,110.80,91.87,91.50,87.46,87.22,75.18,55.45,47.22$, 46.53, 46.39, 40.46, 12.63, 11.67. Analytical data of $\mathbf{3 0 b}, \mathrm{R}_{\mathrm{f}} 0.17$ (3\% methanol in DCM), HR-MS ( $\left.\mathrm{NSI}^{+}, \mathrm{MeCN}\right)$ for $\mathrm{C}_{33} \mathrm{H}_{34} \mathrm{~N}_{2} \mathrm{O}_{7}$. Calc. 593.2258, found $593.2251(\mathrm{M}+$ $\left.\mathrm{Na}^{+}\right),{ }^{1} \mathrm{H}$ NMR $\left(400 \mathrm{MHz}, \mathrm{CDCl}_{3}\right) \delta 8.69(\mathrm{br}, 1 \mathrm{H}), 7.45(m, 2 \mathrm{H}), 7.35(m, 4 \mathrm{H}), 7.32(m$ $1 \mathrm{H}), 7.27(\mathrm{~m}, 2 \mathrm{H}), 7.21(\mathrm{~m}, 1 \mathrm{H}), 6.82(\mathrm{~m}, 4 \mathrm{H}), 6.27(d d, 1 \mathrm{H}, J=8.8,5.9), 4.33(\mathrm{~m}, 1 \mathrm{H})$ $4.05(d d, 1 \mathrm{H}, J=7.5,2.1), 3.78(s, 6 \mathrm{H}), 2.49(m, 2 \mathrm{H}), 2.10(m, 1 \mathrm{H}), 1.77(m, 2 \mathrm{H}), 1.50$ $(m, 3 \mathrm{H}), 1.18(m, 1 \mathrm{H}) .{ }^{13} \mathrm{C}$ NMR $\left(101 \mathrm{MHz}, \mathrm{CDCl}_{3}\right) \delta 163.72,158.91,158.89,150.54$ $145.65,136.86,136.66,135.61,130.22,130.15,128.34,128.18,127.18,113.67$, $111.57,89.85,88.10,87.68,85.01,76.40,55.47,46.99,46.62,46.08,39.32,12.31$.

(3'S, 6'R)-N6-Benzoyl-9-\{2'-Deoxy-6'-O-[4,4'-(dimethoxytriphenyl)methyl]-3 ',5 'ethano- $\beta$-D-ribofuranosyl) adenine $\mathbf{3 1 b}$ To a solution of nucleoside $\mathbf{2 8 b}(80 \mathrm{mg}, 0.21$ $\mathrm{mmol})$ in pyridine $(2 \mathrm{ml})$ was added DMT-Cl $(213 \mathrm{mg} 0.63 \mathrm{mmol})$ in three portions and the mixture was stirred for $24 \mathrm{~h}$ at r.t. The solution was then diluted with ethyl acetate, washed with sat. $\mathrm{NaHCO}_{3}$ and dried over $\mathrm{MgSO}_{4}$. Purification by $\mathrm{FC}(5 \%$ methanol in DCM) yielded compound 31b (129 mg, $0.19 \mathrm{mmol}, 90 \%)$ as a white foam. $\mathrm{R}_{\mathrm{f}} 0.42$ (10\% methanol in DCM), HR-MS $\left(\mathrm{NSI}^{+}, \mathrm{MeOH}\right)$ for $\mathrm{C}_{40} \mathrm{H}_{37} \mathrm{~N}_{5} \mathrm{O}_{6}$. calc: 684.2817 , found: $684.2830\left(\mathrm{M}+\mathrm{H}^{+}\right),{ }^{1} \mathrm{H}$ NMR $\left(400 \mathrm{MHz}, \mathrm{CDCl}_{3}\right) \delta 8.81(s, 1 \mathrm{H}), 8.27(s, 1 \mathrm{H})$ $8.04(m, 2 \mathrm{H}), 7.61(m, 1 \mathrm{H}),, 7.53(m, 2 \mathrm{H}), 7.45(m, 2 \mathrm{H}), 7.35(m, 4 \mathrm{H}), 7.28(m, 2 \mathrm{H})$, $7.22(m, 1 \mathrm{H}), 6.81(m, 4 \mathrm{H}), 6.46(d d, 1 \mathrm{H}, J=9.1,5.4), 4.35(m, 1 \mathrm{H}), 4.21(d d, 1 \mathrm{H}, J=$ 7.4, 3.5), $3.78(s, 6 \mathrm{H}), 2.92(d d, 1 \mathrm{H}, J=13.2,9.2), 2.64(d d, 1 \mathrm{H}, J=13.2,5.5), 2.02(m$ 1H), 1.83-1.58 (m, 3H). ${ }^{13} \mathrm{C}$ NMR (101 MHz, $\left.\mathrm{CDCl}_{3}\right) \delta 171.37,171.24,158.84,153.04$, $150.05,149.74,145.65,141.30,136.90,136.87,136.18,132.97,130.25,129.09$ $128.28,128.23,128.11,127.14,123.95,113.57,90.02,87.58,87.17,85.18,77.43$, $75.85,55.46,47.26,46.60,46.08,39.91$

(3'S, 6'R)-N6-Benzoyl-1-\{2'-Deoxy-6'-O-[4,4'-(dimethoxytriphenyl)methyl]-3 ',5 ' ethano- $\alpha$-and $-\beta$-D-ribofuranosyl] cytosine $(32 a, 32 b)$ To a solution of nucleoside 29a/b (394 mg, $1.1 \mathrm{mmol})$ in pyridine $(6 \mathrm{ml})$ was added DMT-Cl $(1.1 \mathrm{~g} 3.3 \mathrm{mmol})$ in three portions and it was stirred for $24 \mathrm{~h}$ at r.t. The solution was then diluted with ethyl acetate, washed with sat. $\mathrm{NaHCO}_{3}$ and dried over $\mathrm{MgSO}_{4}$. Purification by FC (ethyl acetate/hexane $4: 1$ to $5 \%$ methanol in DCM) yielded the corresponding anomers $\alpha$ and $\beta$, 32a (450 mg, $0.68 \mathrm{mmol}, 62 \%)$ and 32b (217 mg, $0.33 \mathrm{mmol}, 30 \%)$ as white foams. Analytical data for 32a: $\mathrm{R}_{\mathrm{f}} 0.22$ (ethyl acetate/hexane 4:1), HR-MS (NSI${ }^{+}, \mathrm{MeCN}$ ) for $\mathrm{C}_{39} \mathrm{H}_{37} \mathrm{~N}_{3} \mathrm{O}_{7}$. Calc: 660.2704 , found: $660.2724\left(\mathrm{M}+\mathrm{H}^{+}\right),{ }^{1} \mathrm{H}$ NMR $\left(400 \mathrm{MHz}, \mathrm{CDCl}_{3}\right) \delta$ $9.00(b r, 1 \mathrm{H}), 7.87(m, 3 \mathrm{H}), 7.55(m, 1 \mathrm{H}), 7.46(m, 5 \mathrm{H}), 7.36(m, 4 \mathrm{H}), 7.26(m, 2 \mathrm{H})$ $7.21(m, 1 \mathrm{H}), 6.83(m, 4 \mathrm{H}), 6.05(d d, 1 \mathrm{H}, J=7.1,2.1), 4.48(d d, 1 \mathrm{H}, J=7.3,3.8), 4.25$ $(m, 1 \mathrm{H}), 3.79(s, 6 \mathrm{H}), 3.03(d d, 1 \mathrm{H}), 2.64(d d, 1 \mathrm{H}, \mathrm{J}=14.8,2.0), 1.64(m, 3 \mathrm{H}) .{ }^{13} \mathrm{C}$ NMR $(101 \mathrm{MHz},) \delta 162.60,158.72,155.27,146.01,145.82,137.07,137.03,133.27$ $133.14,130.26,129.08,128.32,128.10,127.87,126.98,113.43,96.20,93.05,92.81$, $87.17,86.83,75.04,60.59,55.40,47.40,46.27,40.51,21.22,14.37$. Analytical data for 43b: $\mathrm{R}_{\mathrm{f}} 0.05$ (ethyl acetate/hexane 4:1), HR-MS $\left(\mathrm{NSI}^{+}, \mathrm{MeCN}\right.$ ) for $\mathrm{C}_{39} \mathrm{H}_{37} \mathrm{~N}_{3} \mathrm{O}_{7}$. Calc: 660.2704, found: $660.2704\left(\mathrm{M}+\mathrm{H}^{+}\right),{ }^{1} \mathrm{H}$ NMR $(300 \mathrm{MHz}, \mathrm{CDCl} 3) \delta 8.77(b r, 1 \mathrm{H})$ $8.23(\mathrm{~m}, 1 \mathrm{H}), 7.89(\mathrm{~m}, 2 \mathrm{H}), 7.60(\mathrm{~m}, 1 \mathrm{H}), 7.51(\mathrm{~m}, 4 \mathrm{H}), 7.37-7.19(m, 8 \mathrm{H}), 6.84(\mathrm{~m}$, $4 \mathrm{H}), 6.45(d d, 1 \mathrm{H}, \mathrm{J}=8.6,5.5), 4.37(m, 1 \mathrm{H}), 4.23(d, 1 \mathrm{H}, \mathrm{J}=5.8), 3.79,3.77(2 s, 6 \mathrm{H})$ $2.84(d d, 1 \mathrm{H}, \mathrm{J}=13.5,5.4), 2.36(d d, 1 \mathrm{H}, \mathrm{J}=13.5,8.7), 1.88-1.73(\mathrm{~m}, 3 \mathrm{H}), 1.42(\mathrm{~m}$ $1 \mathrm{H}) .{ }^{13} \mathrm{C}$ NMR $\left(126 \mathrm{MHz}, \mathrm{CDCl}_{3}\right) \delta 158.87,158.37,145.45,136.83,136.71,133.38$, $130.28,130.20,129.26,128.35,128.31,127.76,127.17,113.62,113.51,90.84,89.31$ $88.06,87.68,87.12,76.79,55.43,55.42,47.10,39.46$.

(3'S, 6'R)-1-\{6'-O-[(2-Cyanoethoxy)(diisopropylamino)phosphino]-2'-deoxy-6'-O $\left[\left(4,4^{\prime}\right.\right.$-dimethoxytriphenyl)methyl]-3',5'-ethano- $\beta$-D-ribofuranosyl $]$ thymine $33 b$ Compound 30b $(163 \mathrm{mg}, 0.29 \mathrm{mmol})$ was dissolved in $\mathrm{MeCN}(2.5 \mathrm{ml})$ and Hünig's base $(0.24 \mathrm{ml}, 1.43 \mathrm{mmol})$ and $\mathrm{Cep}-\mathrm{Cl}(0.19 \mathrm{ml}, 0.87 \mathrm{mmol})$ were added. The solution was stirred at r.t. for $1 \mathrm{~h}$, diluted with ethyl acetate and washed with sat. $\mathrm{NaHCO}_{3}$. The aqueous layer is extracted with ethyl acetate and dried over $\mathrm{MgSO}_{4}$. Purification by FC (ethyl acetate/hexane 1:1) yielded phosphoramidite 33b (214 mg, $0.24 \mathrm{mmol}, 72 \%$ ) as a white foam. ${ }^{31} \mathrm{P}-\mathrm{NMR}$ showed no phosponate peak, therefore no further purification was necessary. $\mathrm{R}_{\mathrm{f}} 0.63$ (ethyl acetate/hexane 2:1), HR-MS ( $\mathrm{NSI}^{+}, \mathrm{MeCN}$ ) for $\mathrm{C}_{42} \mathrm{H}_{51} \mathrm{~N}_{4} \mathrm{O}_{8} \mathrm{P}$. Calc. 771.3517, found $771.3531\left(\mathrm{M}+\mathrm{H}^{+}\right),{ }^{1} \mathrm{H}$ NMR $\left(400 \mathrm{MHz}, \mathrm{CDCl}_{3}\right) \delta 8.11(b r, 1 \mathrm{H})$, $7.45(m, 2 \mathrm{H}), 7.35(m, 4 \mathrm{H}), 7.27(m, 4 \mathrm{H}), 7.20(m, 1 \mathrm{H}), 6.82(m, 4 \mathrm{H}), 6.23(d d, 1 \mathrm{H}, J=$ $9.6,4.9), 4.33(m, 1 \mathrm{H}), 4.27(d d, 1 \mathrm{H}, J=14.8,7.5), 3.79(m, 6 \mathrm{H}), 3.80-3.55(m, 4 \mathrm{H})$ $2.85(m, 1 \mathrm{H}), 2.64(m, 1 \mathrm{H}), 2.58(t, 1 \mathrm{H}, J=6.3), 2.52(m, 1 \mathrm{H}), 2.19(m, 2 \mathrm{H}), 1.70(m$ $1 \mathrm{H}), 1.50(\mathrm{~m}, 3 \mathrm{H}), 1.16(\mathrm{~m}, 9 \mathrm{H}), 1.10(\mathrm{~m}, 3 \mathrm{H}), 1.05(m, 1 \mathrm{H}) .{ }^{13} \mathrm{C}$ NMR $(101 \mathrm{MHz}$, $\left.\mathrm{CDCl}_{3}\right) \delta 163.59,158.89,150.19,145.61,136.87,136.59,135.70,130.24,130.14$ $128.35,128.19,127.18,113.69,111.30,91.69,89.46,88.19,85.18,77.44,76.32,76.20$ $60.62,58.17,57.99,55.47,43.66,43.51,38.94,38.85,24.76,24.53,24.45,20.56$, $14.41,12.30,12.26 .{ }^{31} \mathrm{P}$ NMR $\left(122 \mathrm{MHz}, \mathrm{CDCl}_{3}\right) \delta 142.13,141.81$.

(3'S, 6'R)-N6-Benzoyl-9-\{3'-O-[(2-cyanoethoxy)(diisopropylamino)phosphino]-2'deoxy-6'-O-[4,4'-dimethoxytriphenyl)methyl]-3 ',5'-ethano- $\beta$-D-ribofuranosyl] adenine 34b Compound 31b (290 ng, $0.42 \mathrm{mmol})$ was dissolved in $\mathrm{MeCN}(4 \mathrm{ml})$ and Hünig's base $(0.36 \mathrm{ml}, 2.1 \mathrm{mmol})$ and $\mathrm{Cep}-\mathrm{Cl}(0.28 \mathrm{ml}, 1.3 \mathrm{mmol})$ were added. The solution was stirred at r.t. for $1 \mathrm{~h}$, diluted with ethyl acetate and washed with sat. $\mathrm{NaHCO}_{3}$. The aqueous layer was extracted with ethyl acetate and the organig layers dried over $\mathrm{MgSO}_{4}$. Purification by FC (ethyl acetate/hexane 1:1) yielded phosphoramidite 34b (310 mg, $0.35 \mathrm{mmol}, 83 \%$ ) as a white foam. ${ }^{31} \mathrm{P}$-NMR showed a $\mathrm{H}$-phosphonate peak. Compound 34b had therefore to be further purified. 34b was dissolved in $1 \mathrm{ml}$ of DCM and added dropwise to icecold hexane. The filter cake is collected by washing the filter with DCM and evaporate the solvent. ${ }^{31} \mathrm{P}-\mathrm{NMR}$ showed no more phosphonate so the pure phosphoramidite $\mathbf{3 4 b}\left(325 \mathrm{mg}, 0.37 \mathrm{mmol}, 87 \%\right.$ ) could be collected. $\mathrm{R}_{\mathrm{f}} 0.48$ (ethyl acetate/hexane 2:1), HR-MS $\left(\mathrm{NSI}^{+}, \mathrm{MeCN}\right)$ for $\mathrm{C}_{49} \mathrm{H}_{54} \mathrm{~N}_{7} \mathrm{O}_{7} \mathrm{P}$. calc: 884.3901 , found: $884.3902\left(\mathrm{M}+\mathrm{H}^{+}\right),{ }^{1} \mathrm{H}$ NMR $\left(300 \mathrm{MHz}, \mathrm{CDCl}_{3}\right) \delta 9.07(s, 1 \mathrm{H}), 8.83(d, 1 \mathrm{H}, J=3.2)$, $8.26(s, 1 \mathrm{H}), 8.04(m, 2 \mathrm{H}), 7.61(m, 1 \mathrm{H}), 7.55(m, 2 \mathrm{H})), 7.46(m, 2 \mathrm{H}), 7.36(m, 4 \mathrm{H}), 7.32$ $(m, 2 \mathrm{H}), 6.82(m, 4 \mathrm{H}), 6.45(m, 1 \mathrm{H}), 4.36(m, 2 \mathrm{H}), 3.78(s, 6 \mathrm{H}), 3.74-3.54(m, 4 \mathrm{H}), 3.05$ $(m, 2 \mathrm{H}), 2.63(t, 1 \mathrm{H}, J=6.3), 2.55(t, 1 \mathrm{H}, J=6.3), 2.08(m, 1 \mathrm{H}), 1.90(m, 2 \mathrm{H}), 1.50(m$ $1 \mathrm{H}), 1.16(m, 9 \mathrm{H}),, 1.10(d, J=6.8,3 \mathrm{H}) .{ }^{13} \mathrm{C} \mathrm{NMR}\left(101 \mathrm{MHz}, \mathrm{CDCl}_{3}\right) \delta 164.71$, $158.73,153.02,151.71,145.59,141.41,141.28,136.85,136.80,134.02,132.86$ $130.21,130.16,129.02,128.22,128.15,128.00,127.02,123.21,117.78,117.72$, $113.49,91.16,91.07,91.04,90.95,89.89,89.71,89.68,89.64,87.60,87.55,85.26$, $85.11,77.36,75.67,75.53,58.11,58.03,57.93,57.85,55.38,45.48,45.40,45.12$, $43.60,43.56,43.48,43.43,39.35,39.32,24.73,24.67,24.50,24.47,24.39,20.56$, 20.48, 20.40. ${ }^{31} \mathrm{P}$ NMR $\left(122 \mathrm{MHz}, \mathrm{CDCl}_{3}\right) \delta 142.13,142.07$.

(3'S, 6'R)-N6-Benzoyl-1-\{3'-O-[(2-cyanoethoxy)(diisopropylamino)phosphino]-2' deoxy-6'-O-[4,4'-dimethoxytriphenyl)methyl]-3',5'-ethano- $\beta$-D-ribofuranosyl] cytosine 35b Compound 32b (216 mg, $0.33 \mathrm{mmol})$ was dissolved in $\mathrm{MeCN}(3 \mathrm{ml})$ and Hünig's base $(0.28 \mathrm{ml}, 1.6 \mathrm{mmol})$ and $\mathrm{Cep}-\mathrm{Cl}(0.22 \mathrm{ml}, 0.99 \mathrm{mmol})$ were added. The solution was stirred at r.t. for $2 \mathrm{~h}$, diluted with ethyl acetate and washed with sat. $\mathrm{NaHCO}_{3}$. The aqueous layer was extracted with ethyl acetate and dried over $\mathrm{MgSO}_{4}$. Purification by FC (ethyl acetate/hexane 1:1) yielded phosphoramidite 35b (214 mg, $0.24 \mathrm{mmol}, 72 \%$ ) as a white foam. ${ }^{31} \mathrm{P}-\mathrm{NMR}$ showed a phosponate peak. Compound 35b had therefore to be further purified. 35b was dissolved in $1 \mathrm{ml}$ of DCM and added dropwise to icecold hexane. The filter cake is collected by washing the filter with DCM and evaporate the DCM. After three cycles and another FC ${ }^{31} \mathrm{P}-\mathrm{NMR}$ showed no more phosphonate so the pure phosphoramidite 35b could be collected. $\mathrm{R}_{\mathrm{f}} 0.4$ (ethyl acetate/hexane 2:1), HR-MS (NSI+, THF) for $\mathrm{C}_{48} \mathrm{H}_{54} \mathrm{~N}_{5} \mathrm{O}_{8} \mathrm{P}$. calc: 860.3788 , found: $860.3789\left(\mathrm{M}+\mathrm{H}^{+}\right),{ }^{1} \mathrm{H}$ NMR $\left(400 \mathrm{MHz}, \mathrm{CDCl}_{3}\right) \delta 8.70(\mathrm{br}, 1 \mathrm{H}), 8.20(\mathrm{~m}, 1 \mathrm{H}), 7.90(\mathrm{~m}$, $2 \mathrm{H}), 7.62(\mathrm{~m}, 1 \mathrm{H}), 7.52(\mathrm{~m}, 2 \mathrm{H}), 7.44(\mathrm{~m}, 2 \mathrm{H}), 7.33(\mathrm{~m}, 5 \mathrm{H}), 7.25(\mathrm{~m}, 3 \mathrm{H}), 6.84(\mathrm{~m}$ $4 \mathrm{H}), 6.24(m, 1 \mathrm{H}), 4.40(m, 2 \mathrm{H}), 3.78(2 s, 6 \mathrm{H}), 3.77-3.53(m, 4 \mathrm{H}), 3.11(d d, 1 \mathrm{H}, 13.9$, 4.7), $2.65(t, 1 \mathrm{H}, \mathrm{J}=6.3), 2.57(t, 1 \mathrm{H}, J=6.4), 2.38(\mathrm{~m}, 1 \mathrm{H}), 2.09(m, 1 \mathrm{H}), 1.85(\mathrm{~m}$, $1 \mathrm{H}), 1.81(m, 1 \mathrm{H}), 1.44(m, 1 \mathrm{H}) 1.15(m, 9 \mathrm{H}), 1.08(m, 3 \mathrm{H}),{ }^{13} \mathrm{C}$ NMR $(101 \mathrm{MHz}$, $\left.\mathrm{CDCl}_{3}\right) \delta 162.21,158.87,158.84,145.37,136.79,136.63,133.33,130.26,130.16$, $129.25,128.32,127.75,127.17,113.63,91.68,91.59,91.52,91.43,90.40,90.34,90.17$, $90.10,88.12,88.09,87.38,87.34,77.43,76.44,76.43,58.25,58.08,58.00,55.48$, $55.42,46.98,46.96,46.74,46.64,46.56,46.33,46.25,45.79,45.68,43.64,43.51$, $39.09,24.79,24.72,24.53,24.47,24.40,24.21,24.13,24.10,22.54,20.54,20.50$ 20.46, 20.42, 14.41, 14.33. ${ }^{31} \mathrm{P}$ NMR (122 MHz, $\left.\mathrm{CDCl}_{3}\right) \delta 149.96,149.68$.

$(3 R, 5 S, 7 S)$-3-methoxyoctahydropentalene-7,5-diol 36b The sugar 10b (1.0 g, 3.6 $\mathrm{mmol})$ was dissolved in $0.2 \mathrm{M} \mathrm{NaOH}$ in 5:4:1 THF/methanol/ $\mathrm{H}_{2} \mathrm{O}(150 \mathrm{ml})$ at $0^{\circ} \mathrm{C}$. The solution was stirred for one hour at $0^{\circ} \mathrm{C}$ and quenched by the addition of ammonium chloride. The solvents were then evaporated and the remains absorbed on silica gel. Purification by FC (5\% methanol in DCM) yielded compound 36b $(618 \mathrm{mg}, 3.5 \mathrm{mmol}$, $97 \%$ ) as a colorless oil. $\mathrm{R}_{\mathrm{f}} 0.14$ (ethyl acetate/hexane 1:1), HR-MS (NSI+, $\mathrm{MeOH}$ ) for $\mathrm{C}_{8} \mathrm{H}_{14} \mathrm{O}_{4}$. Calc. 197.0784, found $197.0788\left(\mathrm{M}+\mathrm{Na}^{+}\right),{ }^{1} \mathrm{H}$ NMR $(300 \mathrm{MHz}, \mathrm{MeOD}) \delta$ $4.98(d d, 1 \mathrm{H}, J=5.8,2.0), 4.40(m, 1 \mathrm{H}), 4.23(d d, 1 \mathrm{H},=6.7,2.3), 3.27(s, 3 \mathrm{H}), 2.27(m$, $2 \mathrm{H}), 2.00(m, 1 \mathrm{H}), 1.94(m, 1 \mathrm{H}), 1.85(m, 1 \mathrm{H}), 1.74(d d, 1 \mathrm{H}, J=13.0,7.9) .{ }^{13} \mathrm{C} \mathrm{NMR}$ (75 MHz, MeOD) $\delta 107.38,90.61,86.83,72.44,55.27,49.70,48.90,42.88$.

tert-butyl(((3R,5S,7S)-3-methoxy-7-(((2,3,3-trimethylbutan-2

yl)silyl)oxy)octahydropentalen-3a-yl)oxy)dimethylsilane $37 \mathbf{b}$ Compound $36 \mathbf{b}(1.7 \mathrm{~g}$, $10.0 \mathrm{mmol}$ ) was dissolved in DMF $(40 \mathrm{ml})$. TBSCl $(3.8 \mathrm{~g}, 25.0 \mathrm{mmol})$ and imidazole $(2.1 \mathrm{~g}, 30.0 \mathrm{mmol})$ were added and the mixture was stirred at $85^{\circ} \mathrm{C}$ for $2 \mathrm{~d}$. The solution was then diluted with ethyl acetate, washed with brine and $\mathrm{H}_{2} \mathrm{O}$ and dried over $\mathrm{MgSO}_{4}$. Purification by FC (ethyl acetate/hexane $3: 1)$ yielded $46(3.3 \mathrm{~g}, 8.2 \mathrm{mmol}, 82 \%)$ as colorless oil. $\mathrm{R}_{\mathrm{f}} 0.9$ (ethyl acetate/hexane 1:1), HR-MS (NSI ${ }^{+}$, THF) for $\mathrm{C}_{20} \mathrm{H}_{42} \mathrm{O}_{4} \mathrm{Si}_{2}$. 
Calc. 403.2694, found $403.2693\left(\mathrm{M}+\mathrm{H}^{+}\right),{ }^{1} \mathrm{H} \mathrm{NMR}\left(300 \mathrm{MHz}, \mathrm{CDCl}_{3}\right) \delta 4.99(d d, 1 \mathrm{H}$, $J=5.7,2.2), 4.49(m, 1 \mathrm{H}), 4.25(d, 1 \mathrm{H}, J=6.4), 3.33(s, 3 \mathrm{H}), 2.33(m, 2 \mathrm{H}), 2.00(m$, $2 \mathrm{H}), 1.77(m, 2 \mathrm{H}), 0.88(m, 18 \mathrm{H}), 0.08(m, 12 \mathrm{H}) .{ }^{13} \mathrm{C} \mathrm{NMR}\left(101 \mathrm{MHz}, \mathrm{CDCl}_{3}\right) \delta 105.87$ (C(3)), 89.93 ((C1)), 71.85 (C(7)), 55.13 (OMe), 50.60 (C(4)), 49.47 (C(6)), 41.98 (C(8)), 26.08 (TBS), 25.89 (TBS), 18.42 (TBS), 17.99 (TBS), -2.50 (TBS), -2.55 (TBS)

(3'S, 6'S)- )-2-amino-6-chloro-9-\{3', 6'-di-O-[(tert-butyl)-dimethylsilyl]-2'-deoxy3 ',5'-ethano- $\alpha$ - and - $\beta$-D-ribofuranosyl\} purine $38 \mathrm{a} / \mathbf{b}$ To a suspension of 2'-amino-6' chloropurine $(814 \mathrm{mg}, 4.8 \mathrm{mmol})$ in $\mathrm{MeCN}(11 \mathrm{ml})$ was added BSA (2.3 ml. $9.6 \mathrm{mmol})$ The mixture was stirred at r.t. until a clear solution appeared. Compound $46(858 \mathrm{mg}$, $2.1 \mathrm{mmol}$, in $5 \mathrm{ml} \mathrm{MeCN})$ and TMSOTf $(0.13 \mathrm{ml}, 0.72 \mathrm{mmol})$ was then added and the mixture was stirred for $6 \mathrm{~h}$ at $55^{\circ} \mathrm{C}$. The brownish solution was diluted by the addition of ethyl acetate, washed with sat. $\mathrm{NaHCO}_{3}$ and dried over $\mathrm{MgSO}_{4}$. Purification by FC (ethyl acetate/hexane 1:3) yielded $\mathbf{3 8 b}(411 \mathrm{mg}, 0.76 \mathrm{mmol}, 36 \%)$ and 38a $(316 \mathrm{mg}$, $0.58 \mathrm{mmol}, 28 \%$ ) as white foams. Analytical data of $\mathbf{3 8 b}: \mathrm{R}_{\mathrm{f}} 0.4$ (hexane/ethyl acetate 3:1), HR-MS (NSI ${ }^{+}$, EtOAc) for $\mathrm{C}_{24} \mathrm{H}_{43} \mathrm{~N}_{5} \mathrm{O}_{3} \mathrm{ClSi}_{2}$. Calc: 540.2587 , found: 540.2608 (M $\left.+\mathrm{H}^{+}\right),{ }^{1} \mathrm{H}$ NMR (400 MHz, $\left.\mathrm{CDCl}_{3}\right) \delta 7.87(s, 1 \mathrm{H}), 6.00(d d, 1 \mathrm{H}, \mathrm{J}=9.1,5.6), 5.13(b r$ $2 \mathrm{H}), 4.40(m, 1 \mathrm{H}), 4.31(d, 1 \mathrm{H}, \mathrm{J}=6.3), 2.54(m, 2 \mathrm{H}), 2.34(m, 1 \mathrm{H}), 2.12(m, 1 \mathrm{H}), 1.84$ $(m, 2 \mathrm{H}), 0.90(m, 18 \mathrm{H}), 0.16(m, 6 \mathrm{H}), 0.08(s, 6 \mathrm{H}) .{ }^{13} \mathrm{C}$ NMR $\left(101 \mathrm{MHz}, \mathrm{CDCl}_{3}\right)$ $159.18,153.72,151.77,140.60,126.19,89.88,86.42,83.86,71.80,48.95,47.24,40.71$ $26.05,25.87,18.33,18.03,-2.37,-2.45,-4.42,-4.48$. Analytical data of 38a: $R_{\mathrm{f}} 0.26$ (hexane/ethyl acetate 3:1), HR-MS $\left(\mathrm{NSI}^{+}\right.$, EtOAc) for $\mathrm{C}_{24} \mathrm{H}_{43} \mathrm{~N}_{5} \mathrm{O}_{3} \mathrm{ClSi}_{2}$. Calc: 540.2587, found: $540.2607\left(\mathrm{M}+\mathrm{H}^{+}\right),{ }^{1} \mathrm{H}$ NMR $\left(400 \mathrm{MHz}, \mathrm{CDCl}_{3}\right) \delta 8.19(s, 1 \mathrm{H}), 6.24$ $(d d, 1 \mathrm{H}, J=7.1,1.6), 5.11(b r, 2 \mathrm{H}), 4.45(d, 1 \mathrm{H}, J=6.1), 4.25(m, 1 \mathrm{H}), 2.85(d d, 1 \mathrm{H}, J$ $=14.6,1.5), 2.48(d d, 1 \mathrm{H},=14.6,1.5), 2.30(\mathrm{~m}, 1 \mathrm{H}), 2.12(\mathrm{~m}, 1 \mathrm{H}), 1.90(\mathrm{~m}, 1 \mathrm{H}), 1.81$ $(m, 1 \mathrm{H}), 0.89,0.80\left(2 s, 18 \mathrm{H}_{3}\right), 0.12(s, 3 \mathrm{H}), 0.07(s, 6 \mathrm{H}), 0.02(s, 3 \mathrm{H}) .{ }^{13} \mathrm{C}$ NMR $(101$ $\left.\mathrm{MHz}, \mathrm{CDCl}_{3}\right) \delta 159.15,153.63,151.52,141.11,125.92,91.16,86.93,84.80,71.49$, $50.35,48.48,40.79,26.04,25.79,18.31,17.97,-2.26,-2.55,-4.47,-4.56$.

(3'S, 6'S)- )-9-\{3',6'-di-O-[(tert-butyl)-dimethylsilyl]-2'-deoxy-3',5'-ethano- $\alpha$ - and $-\beta$ D-ribofuranosyl\} guanine $39 \mathrm{a} / \mathrm{b}$ To a solution of 3-hydroxypropionitrile $(0.4 \mathrm{ml}, 5.9$ $\mathrm{mmol})$ in THF $(8 \mathrm{ml})$ at $0^{\circ} \mathrm{C}$ was carefully added $\mathrm{NaH}(60 \%, 285 \mathrm{mg}, 7.1 \mathrm{mmol})$ and the suspension was stirred for $1 \mathrm{~h}$ at r.t. The anomeric compound $\mathbf{3 8 a} / \mathbf{b}$ ( $700 \mathrm{mg}, 1.3$ $\mathrm{mmol}$ in $8 \mathrm{ml}$ THF) was added and the brown mixture was stirred for another $3 \mathrm{~h}$ at $\mathrm{r}$.t. Addition of silica, evaporation of the solvents and filtration (10\% methanol in DCM) over a patch of silica yielded the crude product $39 \mathbf{a} / \mathbf{b}$. The brown foam was used without further purification in the next step. $\mathrm{R}_{\mathrm{f}} 0.5$ (10\% methanol in DCM), HR-MS $\left(\mathrm{NSI}^{+}, \mathrm{MeCN}\right)$ for $\mathrm{C}_{24} \mathrm{H}_{43} \mathrm{~N}_{5} \mathrm{O}_{4} \mathrm{Si}_{2}$. Calc. 521.81, found $522.29\left(\mathrm{M}+\mathrm{H}^{+}\right)$

(3'S, 6'S)- N2-\{N,N-Dimethylformamidino\}-9-\{3',6'-di-O-[(tert-butyl)-dimethylsilyl]2 '-deoxy-3',5'-ethano- $\alpha$ - and - $\beta$-D-ribofuranosyl\} guanine $40 a / b$ The crude compound 39a/b $(750 \mathrm{mg}, \sim 1.4 \mathrm{mmol})$ was dissolved in DMF $(12 \mathrm{ml})$ and $N, N$ dimethylformamide dimethyl acetale $(0.37 \mathrm{ml}, 2.8 \mathrm{mmol})$ was added. The clear yellow solution was stirred for $2 \mathrm{~h}$ at $55^{\circ} \mathrm{C}$. The solvent was evaporated via Kugelroh distillation and purified by FC ( $5 \%$ methanol in DCM) to obtain nucleoside $\mathbf{4 0 a} / \mathbf{b}$ ( 715 $\mathrm{mg}, 1.2 \mathrm{mmol}, 71 \%$ over 2 steps) in an anomeric ratio of $\alpha / \beta \sim 2: 1$ as yellow oil. $\mathrm{R}_{\mathrm{f}} 0.5$ (10\% methanol in DCM), HR-MS (NSI ${ }^{+}$, EtOAc) for $\mathrm{C}_{27} \mathrm{H}_{49} \mathrm{~N}_{6} \mathrm{O}_{4} \mathrm{Si}_{2}$. Calc: 577.3348 , found: $577.3339\left(\mathrm{M}+\mathrm{H}^{+}\right),{ }^{1} \mathrm{H}$ NMR $(300 \mathrm{MHz}, \mathrm{MeOD}) \delta 8.66(s, 1 \mathrm{H}), 8.62(s, 1 \mathrm{H})$ $8.01(2 s, 2 \mathrm{H}), 6.25(d d, 1 \mathrm{H}, J=6.8,1.7), 6.14(d d, 1 \mathrm{H}, J=9.6,5.1), 4.57(\mathrm{~d}, 1 \mathrm{H}, J=$ 6.1), $4.45(\mathrm{~m}, 1 \mathrm{H}), 4.34(\mathrm{~m}, 2 \mathrm{H}), 3.20(\mathrm{~m}, 6 \mathrm{H}), 3.12(\mathrm{~m}, 6 \mathrm{H}), 2.99(\mathrm{~s}, 1 \mathrm{H}), 2.86(\mathrm{~m}, 2 \mathrm{H})$ 2.64-2.36 (m, 5H), $2.12(m, 2 \mathrm{H}), 1.85(m, 4 \mathrm{H}), 0.96(s, 18 \mathrm{H}), 0.92(2 s, 18 \mathrm{H}), 0.77(m$ $12 \mathrm{H}), 0.21(m, 12 \mathrm{H}) .{ }^{13} \mathrm{C}$ NMR $\left(75 \mathrm{MHz}, \mathrm{CDCl}_{3}\right) \delta 158.38,158.28,158.22,157.10$ $156.90,150.37,135.72,118.34,120.54,90.85,89.89,87.00,86.54,84.23,82.88,77.43$ $71.95,71.65,58.07,48.82,48.72,41.56,40.80,35.43,26.02,25.90,25.83,21.70$, $18.27,18.06,18.00,-2.29,-2.46,-2.52,-4.47,-4.54$.

(3'S, 6'S)- N2-\{N,N-Dimethylformamidino\}-9-\{3'-O-[(tert-butyl)-dimethylsilyl]-2'deoxy-3',5'-ethano- $\alpha$ - and - $\beta$-D-ribofuranosyl) guanine $41 \mathbf{a} / \mathbf{b}$ A solution of $40 \mathbf{a} / \mathbf{b}(1.5$ g, $2.6 \mathrm{mmol})$ in THF $(20 \mathrm{ml})$ was cooled to $0{ }^{\circ} \mathrm{C}$. $\mathrm{HF} / \mathrm{Et}_{3} \mathrm{~N}(37 \% \mathrm{HF}, 1.7 \mathrm{ml}, 3.9 \mathrm{mmol})$ was added and allowed to warm to r.t. The reaction mixture was stirred at r.t. over night and then quenched with silica. The solvent was evaporated and the crude mixture purified by FC ( $5 \%$ methanol in DCM). 41a/b $(658 \mathrm{mg}, 1.4 \mathrm{mmol}, 55 \%)$ in an anomeric ratio of $\alpha / \beta \sim 2: 1$ was obtained as a white foam. $\mathrm{R}_{\mathrm{f}} 0.5$ (10\% methanol in DCM), HR-MS ( $\mathrm{NSI}^{+}, \mathrm{MeCN}$ ) for $\mathrm{C}_{21} \mathrm{H}_{34} \mathrm{~N}_{6} \mathrm{O}_{4}$ Si. Calc: 463.2484 , found: $463.2472\left(\mathrm{M}+\mathrm{H}^{+}\right),{ }^{1} \mathrm{H} \mathrm{NMR}$ $(400 \mathrm{MHz}, \mathrm{MeOD}) \delta 8.66(s, 1 \mathrm{H}), 8.62(s, 1 \mathrm{H}), 8.01(s, 1 \mathrm{H}), 7.97(s, 1 \mathrm{H}), 6.24(d d, 1 \mathrm{H}$, $J=6.7,1.6), 6.09(d d, 1 \mathrm{H}, J=10.0,5.1), 4.59(m, 1 \mathrm{H}), 4.53(m, 1 \mathrm{H}), 4.30(m, 1 \mathrm{H}), 4.25$ $(m, 1 \mathrm{H}), 3.21(\mathrm{~m}, 6 \mathrm{H}), 3.12(\mathrm{~m}, 6 \mathrm{H}), 2.92(d d, 1 \mathrm{H}, J=14.6,1.6), 2.71(\mathrm{~m}, 1 \mathrm{H}), 2.60(\mathrm{~m}$ $2 \mathrm{H}), 2.49(\mathrm{~m}, 1 \mathrm{H}), 2.41(\mathrm{~m}, 1 \mathrm{H}), 2.15(\mathrm{~m}, 2 \mathrm{H}), 1.89-1.79(m, 4 \mathrm{H}), 0.95(s, 9 \mathrm{H}), 0.76(s$ $9 \mathrm{H}), 0.22(m, 6 \mathrm{H}), 0.12(s, 3 \mathrm{H}),-0.02(s, 3 \mathrm{H}) .{ }^{13} \mathrm{C}$ NMR (101 MHz, MeOD) $\delta 160.16$ $159.69,159.62,159.00,158.85,151.96,151.43,138.82,138.31,121.07,120.95,92.76$ $91.03,88.52,88.12,87.23,84.98,71.63,71.39,50.21,47.74,41.62,41.45,41.18$, $40.91,35.34,26.24,26.07,18.73,18.56,-2.41,-2.45,-2.48,-2.75$.

(3'S, 6'S)- N2-\{N,N-Dimethylformamidino\}-9-\{6'-O-(methylsulfonyl)-3'-O-[(tert-butyl) dimethylsilyl]-2'-deoxy-3',5'-ethano- $\alpha$ - and $-\beta$-D-ribofuranosyl\} guanine $42 a / b \mathrm{~A}$ solution of $41 \mathrm{a} / \mathrm{b}(243 \mathrm{mg}, 0.53 \mathrm{mmol})$ in pyridine $(5.5 \mathrm{ml})$ was cooled to $0^{\circ} \mathrm{C}$ and $\mathrm{MsCl}(40 \mu 1,0.58 \mathrm{mmol})$ was added. The mixture was stirred for $4 \mathrm{~h}$ at r.t. After the addition of silica the pyridine was evaporated and the crude product purified by FC (5\% methanol in DCM). Compound 42a/b (263 $\mathrm{mg}, 0.49 \mathrm{mmol}, 92 \%)$ in an anomeric ratio of $\alpha / \beta \sim 2: 1$ was obtained as a white solid. $\mathrm{R}_{\mathrm{f}} 0.4$ (10\% methanol in DCM), HR-MS (NSI ${ }^{+}$, EtOAc) for $\mathrm{C}_{22} \mathrm{H}_{36} \mathrm{~N}_{6} \mathrm{O}_{6} \mathrm{SSi}$. Calc: 540.2186 , found: $541.2183\left(\mathrm{M}^{+}\right),{ }^{1} \mathrm{H}$ NMR $\left(400 \mathrm{MHz}, \mathrm{CDCl}_{3}\right) \delta 8.62\left(s, 1 \mathrm{H}, \mathrm{N}=\mathrm{CHN}\left(\mathrm{CH}_{3}\right)_{2}\right), 8.53(s, 1 \mathrm{H}), 7.93(s, 1 \mathrm{H}), 7.79(s$, $1 \mathrm{H}), 6.24(d d, 1 \mathrm{H}, J=7.1,3.7), 6.04(d d, 1 \mathrm{H}, J=9.4,5.4), 5.24-5.13(m, 2 \mathrm{H}), 4.54(\mathrm{~d}$, $1 \mathrm{H}, J=5.4), 4.35(d d, 1 \mathrm{H}, J=6.9,1.6), 3.20(s, 3 \mathrm{H}), 3.18(s, 3 \mathrm{H}), 3.11(s, 6 \mathrm{H}), 3.05(s$, $3 \mathrm{H}), 3.04(s, 3 \mathrm{H}), 2.72(m, 2 \mathrm{H}), 2.61(m, 4 \mathrm{H}), 2.42(m, 2 \mathrm{H}), 2.26-2.12(m, 4 \mathrm{H}), 0.92(s$ $9 \mathrm{H}), 0.87(s, 9 \mathrm{H}), 0.19(s, 3 \mathrm{H}), 0.18(s, 3 \mathrm{H}), 0.15(s, 3 \mathrm{H}), 0.08(s, 3 \mathrm{H}) .{ }^{13} \mathrm{C}$ NMR $(101$ $\left.\mathrm{MHz}, \mathrm{CDCl}_{3}\right) \delta 158.06,157.99,156.93,150.34,136.75,136.43,121.20,89.19,88.54$ $86.97,86.46,83.87,79.69,79.22,47.39,47.30,46.53,46.39,41.70,38.59,38.00$ $37.84,35.50,25.83,25.80,18.04,-2.46,-2.48$.

\section{(3'S, 6'R)- N2-\{N,N-Dimethylformamidino\}-9-\{6'-O-acetyl-3'-O-[(tert-butyl)-} dimethylsilyl]-2'-deoxy-3',5'-ethano- $\alpha$ - and $-\beta$-D-ribofuranosyl\} guanine $43 \mathrm{a} / \mathrm{b} \mathrm{A}$ solution containing $\mathbf{4 2} \mathrm{a} / \mathrm{b}(620 \mathrm{mg}, 1.15 \mathrm{mmol})$ and $\mathrm{CsOAc}(3.0 \mathrm{~g}, 15.9 \mathrm{mmol})$ in DMSO $(16 \mathrm{ml})$ was heated to $85^{\circ} \mathrm{C}$ and stirred for $16 \mathrm{~h}$. After cooling to r.t. the mixture was diluted with ethyl acetate and washed with sat. $\mathrm{NaHCO}_{3}$. The combined organic layers were washed with $\mathrm{H}_{2} \mathrm{O}$ and dried over $\mathrm{MgSO}_{4}$. By FC purification (5\% methanol in DCM) $43 \mathbf{a} / \mathbf{b}(491 \mathrm{mg}, 0.97 \mathrm{mmol}, 85 \%)$ was obtained in an anomeric ratio of $\alpha / \beta \sim 2: 1$ as a white foam. ${ }^{1} \mathrm{H}-\mathrm{NMR}$ showed still a considerable amount of DMSO. $\mathrm{R}_{\mathrm{f}} 0.5$ (10\% methanol in DCM), HR-MS (NSI ${ }^{+}$, EtOAc) for $\mathrm{C}_{23} \mathrm{H}_{36} \mathrm{~N}_{6} \mathrm{O}_{5} \mathrm{Si}$. Calc: 505.2589 , found: $505.2582\left(\mathrm{M}+\mathrm{H}^{+}\right),{ }^{1} \mathrm{H}$ NMR $\left(400 \mathrm{MHz}, \mathrm{CDCl}_{3}\right) \delta 9.72(\mathrm{br}, 2 \mathrm{H}), 8.60(s, 1 \mathrm{H})$ $8.58(s, 1 \mathrm{H}), 7.95(s, 1 \mathrm{H}), 7.89(s, 1 \mathrm{H}), 6.32(m, 1 \mathrm{H}), 6.22(m, 1 \mathrm{H}), 5.34(m, 2 \mathrm{H}), 4.59$ $(m, 1 \mathrm{H}), 4.36(d d, 1 \mathrm{H}, J=6.9,1.3), 3.17(m, 6 \mathrm{H}), 3.10(m, 6 \mathrm{H}), 2.70-2.53(m, 4 \mathrm{H})$, 2.41- $2.28(m, 6 \mathrm{H}) 2.16(m, 2 \mathrm{H}), 2.06(s, 3 \mathrm{H}), 2.05(s, 3 \mathrm{H}), 0.90(s, 9 \mathrm{H}), 0.87(s, 9 \mathrm{H}$, $0.14(m, 12 \mathrm{H}) .{ }^{13} \mathrm{C}$ NMR $\left(101 \mathrm{MHz}, \mathrm{CDCl}_{3}\right) \delta 170.49,158.39,158.13,157.17,156.95$, $150.16,136.83,135.83,132.06,120.35,95.82,91.14,91.03,89.43,89.36,84.92,83.83$, $76.72,76.30,48.04,46.85,46.22,45.88,41.57,37.76,37.59,35.40,25.85,25.80$ $25.74,21.52,21.40,17.99,-2.56,-2.63,-2.73$

(3'S, 6'R)- 9-\{3'-O-[(tert-butyl)-dimethylsilyl $]-2^{\prime}$-deoxy-3',5'-ethano- $\alpha$ - and $-\beta-D$ ribofuranosyl) guanine $(44 a, 44 b)$ The anomeric mixture $43 \mathrm{a} / \mathrm{b}(512 \mathrm{mg}, 1.0 \mathrm{mmol})$ was dissolved in $1 \mathrm{M} \mathrm{KOH}$ in 5:3 methanol/ $\mathrm{H}_{2} \mathrm{O}(12 \mathrm{ml})$. The solution was stirred for 6 $\mathrm{h}$ at $60^{\circ} \mathrm{C}$ and quenched by the addition of ammonium chloride. The solvents were then evaporated and the remains absorbed on silica gel. Purification by FC (5\% methanol in DCM) yielded the anomers $44 \mathrm{~b}(170 \mathrm{mg}, 0.42 \mathrm{mmol}, 42 \%)$ and $\mathbf{4 4 a}(78 \mathrm{mg}, 0.2 \mathrm{mmol}$, $20 \%)$ as white solids. Analytical data for 44a: $\mathrm{R}_{\mathrm{f}} 0.27$ (10\% methanol in DCM), HR-MS ( $\mathrm{NSI}^{+}, \mathrm{MeOH}$ ) for $\mathrm{C}_{18} \mathrm{H}_{29} \mathrm{~N}_{5} \mathrm{O}_{4}$ Si. Calc. 408.2062, found 408.2056 $\left(\mathrm{M}+\mathrm{H}^{+}\right),{ }^{1} \mathrm{H} \mathrm{NMR}$ $(400 \mathrm{MHz}, \mathrm{MeOD}) \delta 7.96(s, 1 \mathrm{H}), 6.19(d d, 1 \mathrm{H}, J=9.5,5.7), 4.48(m, 1 \mathrm{H}), 4.34(d d$ $1 \mathrm{H}, J=7.0,1.7), 2.93(d d, 1 \mathrm{H}, J=13.4,9.6), 2.59(d d, 1 \mathrm{H}, J=13.4,5.7), 2.26(m, 2 \mathrm{H})$, $2.08(d d, 1 \mathrm{H}, J=13.7,5.4), 1.95(m, 1 \mathrm{H}), 0.93(s, 9 \mathrm{H}), 0.19(s, 3 \mathrm{H}), 0.17(s, 3 \mathrm{H}) .{ }^{13} \mathrm{C}$ NMR (101 MHz, MeOD) $\delta$ 159.29, 155.44, 152.66 137.90, 117.66, 93.15, 91.18, 85.41, $74.81,49.30,41.34,26.18,18.69,-2.53,-2.59$. Analytical data for $\mathbf{4 4 b}$ : TLC $R_{\mathrm{f}} 0.27$ (10\% methanol in DCM), HR-MS $\left(\mathrm{NSI}^{+}, \mathrm{MeOH}\right)$ for $\mathrm{C}_{18} \mathrm{H}_{29} \mathrm{~N}_{5} \mathrm{O}_{4} \mathrm{Si}$. Calc. 408.2062 , found $408.2057\left(\mathrm{M}+\mathrm{H}^{+}\right),{ }^{1} \mathrm{H}$ NMR $(400 \mathrm{MHz}, \mathrm{MeOD}) \delta 7.89(s, 1 \mathrm{H}), 6.26(d d, 1 \mathrm{H}, J=$ 6.7, 3.0), $4.66(d d, 1 \mathrm{H}, J=7.0,2.0), 4.45(m, 1 \mathrm{H}), 2.95(d d, 1 \mathrm{H}, J=13.9,6.7), 2.75(d d$, $1 \mathrm{H}, J=13.9,3.0), 2.31(m, 1 \mathrm{H}), 2.14(m, 2 \mathrm{H}), 1.84(m, 1 \mathrm{H}), 0.78(s, 9 \mathrm{H}), 0.11(s, 3 \mathrm{H})$, $0.02(s, 3 \mathrm{H}) .{ }^{13} \mathrm{C}$ NMR $(101 \mathrm{MHz}, \mathrm{MeOD}) \delta 159.33,155.17,152.30,137.30,118.09$ $94.21,91.23,88.09,74.20,49.66,48.90,41.35,26.06,18.57,-2.56,-2.89$.

(3 'S, 6'R)- N2-\{N,N-Dimethylformamidino\}-9-\{3'-O-[(tert-butyl)-dimethylsilyl]-2'deoxy-3',5'-ethano- $\beta$-D-ribofuranosyl\} guanine $45 b$ The nucleoside $44 \mathbf{b}(170 \mathrm{mg}, 0.41$ mmol) was dissolved in DMF (4.5 ml) and N,N-dimethylformamid dimethyl acetale $(0.11 \mathrm{ml}, 0.82 \mathrm{mmol})$ was added. The solution was stirred for $3 \mathrm{~h}$ at $55^{\circ} \mathrm{C}$. The DMF was then evaporated by Kugelrohr distillation and the crude product purified by FC (10\% methanol in DCM). Compound $\mathbf{4 5 b}(122 \mathrm{mg}, 0.26 \mathrm{mmol}, 64 \%)$ was obtained as a white foam. $\mathrm{R}_{\mathrm{f}} 0.3\left(10 \%\right.$ methanol in DCM), HR-MS (NSI $\left.{ }^{+}, \mathrm{MeCN}\right)$ for $\mathrm{C}_{2} 1 \mathrm{H}_{34} \mathrm{~N}_{6} \mathrm{O}_{4} \mathrm{Si}$. Calc. 463.2484, found $463.2475(\mathrm{M}+\mathrm{H}+),{ }^{1} \mathrm{H}$ NMR $\left(400 \mathrm{MHz}, \mathrm{CDCl}_{3}\right) \delta 9.13(s, 1 \mathrm{H}), 8.68$ $(s, 1 \mathrm{H}), 7.87(s, 1 \mathrm{H}), 6.04(d d, 1 \mathrm{H}, J=10.0,5.5), 4.53(m, 1 \mathrm{H}), 4.35(d, 1 \mathrm{H}, J=6.3)$, $3.22(d d, 1 \mathrm{H}, J=13.4,10.1), 3.17(s, 3 \mathrm{H}), 3.07(s, 3 \mathrm{H}), 2.53(d d, 1 \mathrm{H}, J=13.4,5.5)$, $2.40(m, 1 \mathrm{H}), 2.18(m, 1 \mathrm{H}) 2.10(m, 1 \mathrm{H}), 2.01(m, 1 \mathrm{H}), 0.90(m, 9 \mathrm{H}), 0.15(s, 3 \mathrm{H}), 0.13$ $(m, 3 \mathrm{H}) .{ }^{13} \mathrm{C}$ NMR $\left(75 \mathrm{MHz}, \mathrm{CDCl}_{3}\right) \delta 81.93,80.54,79.99,72.95,60.80,44.42,15.14$, $12.56,7.82,0.20,-1.84,-27.06,-29.22,-35.90,-36.81,-42.05,-51.34,-59.19,-79.57$, 79.66 .

(3 'S, 6'R)- N2-\{N,N-Dimethylformamidino $\}-9-\left\{5^{\prime}-O-\left[4,4^{\prime}\right.\right.$-(dimethoxytriphenyl)methyl]3'-O-[(tert-butyl)-dimethylsilyl]-2'-deoxy-3',5'-ethano- $\beta$-D-ribofuranosyl] guanine 46b To a solution of nucleoside $45 \mathrm{~b}(70 \mathrm{mg}, 0.15 \mathrm{mmol})$ in pyridine $(0.7 \mathrm{ml})$ was added DMT-Cl $(154 \mathrm{mg} 0.45 \mathrm{mmol})$ in three portions and it was stirred for $24 \mathrm{~h}$ at r.t. The solution was then diluted with ethyl acetate, washed with sat. $\mathrm{NaHCO}_{3}$ and dried over $\mathrm{MgSO}_{4}$. Purification by FC (5\% methanol in DCM) yielded the nucleoside $46 \mathrm{~b}$ (108 mg, $0.14, \mathrm{mmol}, 94 \%)$ as a white foam. $\mathrm{R}_{\mathrm{f}} 0.66\left(10 \%\right.$ methanol in DCM), HR-MS (NSI ${ }^{+}$, $\mathrm{MeCN}$ ) for $\mathrm{C}_{42} \mathrm{H}_{52} \mathrm{~N}_{6} \mathrm{O}_{6} \mathrm{Si}$. Calc. 765.3790, found $765.3779\left(\mathrm{M}+\mathrm{H}^{+}\right),{ }^{1} \mathrm{H}$ NMR (300 $\left.\mathrm{MHz}, \mathrm{CDCl}_{3}\right) \delta 8.94(\mathrm{br}, 1 \mathrm{H}), 8.61(\mathrm{~s}, 1 \mathrm{H}), 7.88(\mathrm{~m}, 1 \mathrm{H}), 7.47(\mathrm{~m}, 2 \mathrm{H}), 7.36(m, 4 \mathrm{H})$, $7.30(m, 1 \mathrm{H}), 7.20(m, 1 \mathrm{H}), 6.83(m, 4 \mathrm{H}), 6.19(d d, 1 \mathrm{H}, J=9.6,5.1), 4.27(m, 1 \mathrm{H}), 4.12$ $(d d, 1 \mathrm{H}, J=7.5,3.9), 3.79(s, 6 \mathrm{H}), 3.13(s, 3 \mathrm{H}), 3.10(s, 3 \mathrm{H}), 2.73(d d, 1 \mathrm{H}, J=13.0$ 9.6), $2.42(d d, 1 \mathrm{H}, J=13.0,5.1), 1.98(m, 1 \mathrm{H}), 1.68(m, 1 \mathrm{H}), 1.60(m, 2 \mathrm{H}), 0.83(s$, $9 \mathrm{H},), 0.04(s, 3 \mathrm{H}),-0.04(s, 3 \mathrm{H}) .{ }^{13} \mathrm{C}$ NMR $\left(75 \mathrm{MHz}, \mathrm{CDCl}_{3}\right) \delta 158.86,158.29,157.96$, 
$156.81,150.17,145.69,136.96,136.21,130.28,128.28,128.22,127.11,113.55,90.76$ $88.62,87.44,84.73,75.66,55.47,46.96,45.56,41.51,39.70,35.37,25.88,18.02,-2.63$

(3'S, 6'R)-N2-\{N,N-Dimethylformamidino\}-9-\{6'-O-[4,4'-(dimethoxytriphenyl)methyl]2'-deoxy-3',5'-ethano- $\beta$-D-ribofuranosyl\} guanine $47 \mathrm{~b}$ Nucleoside $46 \mathrm{~b}$ (74 mg, 0.1 mmol) was dissolved in THF (2.2 ml) and TBAF ( $1 \mathrm{M}$ in THF, $0.1 \mathrm{ml}, 0.1 \mathrm{mmol})$ was added. The clear solution was stirred for $5 \mathrm{~h}$ at r.t. and then quenched by the addition of silica. Purification by FC (5\% methanol in DCM) yielded 47b (44 mg, $70 \%)$ as a white foam. $\mathrm{R}_{\mathrm{f}} 0.4$ (10\% methanol in DCM), HR-MS $\left(\mathrm{NSI}^{+}, \mathrm{MeCN}, 0.1 \% \mathrm{HFo}\right.$ ) for $\mathrm{C}_{36} \mathrm{H}_{38} \mathrm{~N}_{6} \mathrm{O}_{6}$. Calc. 651.2926, found $651.2925\left(\mathrm{M}+\mathrm{H}^{+}\right)^{1} \mathrm{H}$ NMR (400 MHz, MeOD) $\delta$ $8.68(s, 1 \mathrm{H}), 7.97(s, 1 \mathrm{H}), 7.46(m, 2 \mathrm{H}), 7.34(m, 4 \mathrm{H}), 7.27(m, 2 \mathrm{H}), 7.21(m, 1 \mathrm{H}), 6.84$ $(m, 4 \mathrm{H}), 6.24(d d, 1 \mathrm{H}, J=9.4,5.4), 4.33(m, 1 \mathrm{H}), 4.08(d d, 1 \mathrm{H}, J=7.4,3.4), 3.78(s$ $6 \mathrm{H}), 3.16(s, 3 \mathrm{H}), 3.12(s, 3 \mathrm{H}), 2.91(d d, 1 \mathrm{H}, J=13.1,9.5), 2.49(d d, 1 \mathrm{H}, J=13.2,5.4)$ $1.95(m, 1 \mathrm{H}), 1.82(m, 1 \mathrm{H}), 1.67(d d, 1 \mathrm{H}, J=14.0,6.1), 1.57(m, 1 \mathrm{H}) .{ }^{13} \mathrm{C}$ NMR $(10$ $\mathrm{MHz}, \mathrm{MeOD}) \delta 160.25,159.82,159.17,151.84,147.10,138.25,138.09,138.06$ $131.32,129.33,128.92,127.86,120.65,114.27,90.89,88.62,87.54,85.98,77.02$ $55.73,47.44,46.93,41.52,40.74,35.33$.

(3'S, 6'R)-N2-\{N,N-Dimethylformamidino\}-9-\{3'-O-[(2 cyanoethoxy)(diisopropylamino)phosphino]-6'-O- [4,4'-(dimethoxytriphenyl)methyl] 3'-O-[(tert-butyl)-dimethylsilyl]-2'-deoxy-3',5'-ethano- $\beta$-D-ribofuranosyl] guanine 48 To a solution of $47 \mathbf{b}(44 \mathrm{mg}, 0.07 \mathrm{mmol})$ in $\mathrm{MeCN}(1 \mathrm{ml})$ was added Hünig's base $(0.06 \mathrm{ml}, 0.34 \mathrm{mmol})$ and $\mathrm{Cep}-\mathrm{Cl}(0.04 \mathrm{ml}, 0.2 \mathrm{mmol})$. The mixture was stirred at r.t. for $1 \mathrm{~h}$ then diluted with ethyl acetate and washed with sat. $\mathrm{NaHCO}_{3}$. Purification by FC (3\% methanol in DCM) yielded the desired phosphoramidite $48 \mathbf{b}(50 \mathrm{mg}, 0.06 \mathrm{mmol}$ $88 \%$ ) as a white foam. $\mathrm{R}_{\mathrm{f}} 0.7\left(10 \%\right.$ methanol in DCM), HR-MS ( $\mathrm{NSI}^{+}, \mathrm{MeCN}$ ) for $\mathrm{C}_{45} \mathrm{H}_{55} \mathrm{~N}_{8} \mathrm{O}_{7} \mathrm{P}$. Calc. 851.4010, found $851.4009\left(\mathrm{M}+\mathrm{H}^{+}\right),{ }^{1} \mathrm{H}$ NMR $(400 \mathrm{MHz}, \mathrm{CDCl} 3)$ $\delta 8.95(b r, 1 \mathrm{H}), 8.60(m, 1 \mathrm{H}), 7.85(m, 1 \mathrm{H}), 7.45(m, 2 \mathrm{H}), 7.35(m, 4 \mathrm{H}), 7.28(m, 2 \mathrm{H})$ $7.21(\mathrm{~m}, 1 \mathrm{H}), 6.83(\mathrm{~m}, 4 \mathrm{H}), 6.22(\mathrm{~m}, 1 \mathrm{H}), 4.32(\mathrm{~m}, 2 \mathrm{H}), 3.79(\mathrm{~m}, 6 \mathrm{H}), 3.77-3.54(\mathrm{~m}$ $4 \mathrm{H}), 3.13(s, 3 \mathrm{H}), 3.09(m, 3 \mathrm{H}), 2.84(m, 2 \mathrm{H}), 2.57(t, 1 \mathrm{H}, J=6.3), 2.51(t, 1 \mathrm{H}, J=6.3)$ $2.09(m, 1 \mathrm{H}), 1.86(m, 2 \mathrm{H}), 1.60(m, 1 \mathrm{H}), 1.15(m, 9 \mathrm{H}), 1.09(d, 3 \mathrm{H}, J=6.8) .{ }^{13} \mathrm{C}$ NMR $\left(101 \mathrm{MHz}, \mathrm{CDCl}_{3}\right) \delta 158.80,158.33,158.00,156.94,156.88,150.38,150.30,145.66$ $136.87,136.83,136.38,130.30,130.25,128.24,127.08,120.90,117.75,113.53,90.91$ $90.82,90.76,89.12,87.55,87.52,84.33,75.62,75.51,58.20,58.02,57.92,55.46$ $44.92,44.60,43.59,43.47,41.50,39.41,35.36,29.89,24.75,24.50,20.53 .{ }^{31} \mathrm{P}$ NMR $\left(122 \mathrm{MHz}, \mathrm{CDCl}_{3}\right) \delta 141.88$.

RNase $H$ activity: A $0.2 \mu \mathrm{M}$ solution of the oligonucleotide S10 and of the corresponding DNA and RNA strands was solved in a buffer system containing $75 \mathrm{mM}$ $\mathrm{KCl}, 50 \mathrm{mM}$ Tris- $\mathrm{HCl}, 3 \mathrm{mM} \mathrm{MgCl}_{2}$ and $10 \mathrm{mM}$ dithiothreitol and was then hybridized with $0.1 \mu \mathrm{M}$ of the ${ }^{32} \mathrm{P}$ labelled complementary RNA strand to give a total volume of 60 $\mu$ l. After heating to $80^{\circ} \mathrm{C}$ the solution was incubated for $15 \mathrm{~min}$. at $37^{\circ} \mathrm{C}$. $2.5 \mathrm{U}$ of the enzyme were then added and the mixture was kept at $25^{\circ} \mathrm{C}$. Aliquots were taken at 5 , 45,120 and $300 \mathrm{~min}$. and were quenched by the addition of a loading buffer $(100 \%$ formamid, bromphenol blue and xylencyanol). The samples were stored at $4{ }^{\circ} \mathrm{C}$ ove night, analysed on a $20 \%$ denaturing polyacrylamide gel and the bands visualized by autoradiography.

Serum stability: $202 \mu \mathrm{l}$ of the sequence S10 and $108 \mu \mathrm{l}$ of the corresponding DNA sequence $(\sim 30 \mu \mathrm{g}$ each) were speed vac dried. The remains were taken up in $386 \mu$ DMEM/F12 (Dulbecco's Modified Eagle Medium), incubated at $37^{\circ} \mathrm{C}$ and $40 \mu \mathrm{l}$ of FBS was added to give a total concentration of $10 \%$ serum. Aliquots of $84 \mu 1$ were taken after $0,0.5,2,6.5$ and $21 \mathrm{~h}$ and quenched by the addition of $80 \mu 19 \mathrm{M}$ urea in $2 \mathrm{x}$ TBE buffer. To the solutions were then added $60 \mu 1$ of $\mathrm{H}_{2} \mathrm{O}$ and they were precipitated in 25 $\mu 13 \mathrm{M} \mathrm{NaOAc}$ and $1 \mathrm{ml}$ cold ethanol. After $1 \mathrm{~h}$ at $-80^{\circ} \mathrm{C}$ the tubes were centrifuged fo $1 \mathrm{~h}$ at $2{ }^{\circ} \mathrm{C}$. The remains were taken up in $15 \mu$ loading buffer (formamide/TBE 9:1) and separarated on a $20 \%$ polyacrylamide gel. In order to visualize the bands the get was stained with stains-all.

iso-bicyclo oligonucleotide synthesis: The chemical synthesis of oligonucleotides was performed on the $1.3 \mu \mathrm{mol}$ scale on a Pharmacia LKB Gene Assembler Special DNA synthesizer using standard phosphoramidite chemistry. The phosphoramidite building blocks of the natural nucleosides and the nucleosides bound to CPG-solid support were purchased from Glen Research. Universal solid support was purchased from Glen Research or CTGen. Natural oligonucleotides were purchased from Microsynth. Solvents and reagents used for the synthesis were prepared according to the manufacturer's indications. 5-(ethylthio)-1H-tetrazole (ETT) was used as activator and dichloroacetic acid in dichloroethane was used for the detritylation step. The concentrations of the phosphoramidite solutions were $0.1 \mathrm{M}$. The coupling times for natural phosphoramidites were $1.5 \mathrm{~min}$ and for the modified phosphoramidite $9 \mathrm{~min}$ The oligonucleotides S1-S4 were cleaved from the resin and deprotected in $33 \% \mathrm{NH}_{3}$ solution at $55^{\circ} \mathrm{C}$ overnight. Also the fully modified sequences S6, S7, S10, S11 were cleaved and deprotected in $33 \% \mathrm{NH}_{3}$ but at $70^{\circ} \mathrm{C}$ overnight. After evaporation the crude samples were filtered, taken up in water and purified by reversed phase (Source 15 RPC ST 100/4.6 Polystyrene-15 column from Pharmacia Biotech) or DEAE-HPLC (DNAPac-200 4 × $250 \mathrm{~mm}$ column with pre-column both from Dionex). All sample were then desalted over a Sep-Pak ${ }^{\circledR}$ C-18 cartridge (Waters) according to the manufacturer's protocol. The integrity of all oligonucleotides was confirmed by ESI-
MS spectrometry. Concentrations of the oligonucleotide solutions were determined by UV absorption at $260 \mathrm{~nm}$. The extinction coefficients $\varepsilon$ of the oligonucleotides were supposed to be identical to natural oligonucleotides and were calculated using the oligocalculator (www.ambion.com).

UV/Vis Spectroscopy: Thermal denaturation experiments were measured on a Cary 100 Bio, UV-Visible Spectrophotometer. The samples were measured at $260 \mathrm{~nm}$ and the heating rate was set to $0.5^{\circ} \mathrm{C} / \mathrm{min}$. The first derivatives of the curves were calculated with the Origin Pro 8 program. To avoid evaporation of the solution, a layer of dimethylpolysiloxane was added over the samples within the cell. The OD values of the oligonucleotides were measured with a NanoDrop ND-1000 Spectrophotometer at 260 $\mathrm{nm}$

Circular dichroism spectroscopy $(C D)$ : Circular dichroism spectra were recorded on a Jasco J-715 spectropolarimeter equipped with a Jasco PFO-350S temperature controller. The temperature was measured from the heating block. The graphs were subsequently smoothed with a noise filter. The phosphate buffer was used as blank Spectra are given in mdeg from 210 to $320 \mathrm{~nm}$.

Molecular modeling: Molecular modeling were carried out with the Amber force field as incorporated in the software package HyperChem ${ }^{\mathrm{TM}}$ Release 8.0.4 for Windows of Hypercube, Inc. Only original Amber parameters were used and no explicit water or counterions were included.

\section{Acknowledgements}

We thank the Swiss National Science Foundation and the Association Monégasque contre les Myopathies (AMM) for financial support of this project.

[1] J. Kurreck, Angew. Chem. Int. Ed. 2009, 48, 1378-1398.

[2] C. F. Bennett, E. E. Swayze, Annu. Rev. Pharmacol. Toxicol. 2010, 50, 259-293.

[3] The ENCODE project consortium, Nature 2012, 489, 57-74.

[4] a) J. C. van Deutekom, A. A. Janson, I. B. Ginjaar, W. S. Frankhuizen, A Aartsma-Rus, M. Bremmer-Bout, J. T. den Dunnen, K. Koop, A. J. van der Kooi, N. M. Goemans, S. J. de Kimpe, P. F. Ekhart, E. H. Venneker, G. J. Platenburg, J. J. Verschuuren, G. J. van Ommen, N. Engl. J. Med. 2007, 357 2677-2686; b) M. Manoharan, Biochim. Biophys. Acta 1999, 1489, 117-130.

[5] H. M. Moulton, J. D. Moulton, Biochim. Biophys. Acta 2010, 1798, 2296-2303.

[6] M. Egholm, O. Buchardt, L. Christensen, C. Behrens, S. M. Freier, D. A. Driver, R. H. Berg, S. K. Kim, B. Norden, P. E. Nielsen, Nature 1993, 365, 566-568.

[7] a) S. K. Singh, P. Nielsen, A. A. Koshkin, J. Wengel, Chem. Comm. 1998, 455456; b) S. Obika, D. Nanbu, Y. Hari, J. I. Andoh, K. I. Morio, T. Doi, T. Imanishi, Tetrahedron Lett. 1998, 39, 5401-5404.

[8] a) M. Bolli, H. U. Trafelet, C. Leumann, Nucleic Acids Research 1996, 24 4660-4667; b) M. Tarköy, M. Bolli, C. Leumann, Helv. Chim. Acta 1994, 77 716-744; c) M. Tarköy, C. Leumann, Angew. Chem. Intl. Ed. 1993, 32, 14321434; d) P. Silhár, C. J. Leumann, Bioorg. Med. Chem. 2010, 18, 7786-7793.

[9] a) D. Renneberg, C. Leumann, J. Am.- Chem. Soc. 2002, 124, 5993-6002; b) S Murray, D. Ittig, E. Koller, A. Berdeja, A. Chappell, T. P. Prakash, M. Norrbom, E. E. Swayze, C. J. Leumann, P. P. Seth, Nucleic Acids Res. 2012, 40, 61356143; c) J. Lietard, C. J. Leumann, J. Org. Chem. 2012, 77, 4566-4577.

[10] R. Steffens, C. Leumann, Helv. Chim. Acta 1997, 80, 2426-2439.

[11] R. Meier, S. Grüschow, C. J. Leumann, Helv. Chim. Acta 1999, 82, 1813-1828.

[12] X.-F. Zhu, H. J. Williams, A. I. Scott, J. Chem. Soc., Perkin Trans 12000 2305-2306.

[13] J. H. van de Sande, N. B. Ramsing, M. W. Germann, W. Elhorst, B. W. Kalisch, E. von Kitzing, R. T. Pon, R. C. Clegg, T. M. Jovin, Science 1988, 551-557.

[14] C. Hendrix, H. Rosemeyer, I. Verheggen, F. Seela, A. Van Aerschot, P. Herdewijn, Chem. Eur. J. 1997, 3, 110-120.

[15] a) A. K. Shchyolkina, Y. P. Lysov, I. A. Il'ichove, A. A. Chernyi, Y. B. Golova, B. K. Chernov, B. P. Gottikh, V. L. Florentiev, FEBS Lett. 1989, 244, 39-42; b) A. K. Shchyolkina, O. F. Borisova, M. A. Livshits, G. E. Pozmogova, B. K. Chernov, R. Klement, T. M. Jovin, Biochemistry 2000, 10034-10044.

[16] M. Petersheim, D. H. Turner, Biochemistry 1983, 22, 256-263.

[17] G. S. Manning, Acc. Chem. Res. 1979, 11, 443-449. 
[18] Circular Dichroism: Principles and Applications, second ed., John Wiley \& Sons, 2002.

[19] L. Bellon, J.-L. Barascut, G. Maury, G. Divita, R. Goody, J.-L. Imbach, Nucleic Acids Res. 1993, 21, 1587-1593.

[20] J. Wang, B. Verbeure, I. Luyten, E. Lescrinier, M. Froeyen, C. Hendrix, H Rosemeyer, F. Seela, A. van Aerschot, P. Herdewijn, J. Am. Chem. Soc. 2000, $122,8595-8602$.

[21] J. Kypr, I. Kejnovska, D. Renciuk, M. Vorlickova, Nucleic Acids Res. 2009, 37, $1713-1725$.

[22] M. Vorlickova, J. Kypr, V. Sklenar, A. Klug, J. Mol. Biol. 1983, 166, 85-92.

[23] N. G. A. Abrescia, A. Thompson, T. Huynh-Dinh, J. A. Subirana, Proc. Natl Acad. Sci. USA 2002, 99, 2806-2811.

[24] a) A. K. Shchyolkina, O. F. Borisova, M. A. Livshits, T. M. Jovin, J. Mol. Biol. 2003, 37, 223-231; b) C. Otto, G. A. Thomas, T. M. Jovin, W. L. Peticolas, Biochemistry 1991, 30, 3062-3069.

[25] a) W. F. Lima, S. T. Crooke, Biochemistry 1997, 36, 390-398; b) W. F. Lima, V. Mohan, J. Biol. Chem. 1997, 272, 18191-18199.
[26] E. Zamaratski, P. I. Pradeepkumar, J. Chattopadhyaya, J. Biochem. Biophys. Methods 2001, 48, 189-208.

[27] D. Yu, R. P. Iyer, D. R. Shaw, J. Lisziewicz, Y. Li, Z. Jiang, A. Roskey, S. Agrawal, Bioorg. Med. Chem. 1996, 4, 1685-1692.

[28] C. Wahlestedt, P. Salmi, L. Good, J. Kela, T. Johnsson, T. Hökfelt, C. Broberger, F. Porreca, J. Lai, K. Ren, M. Ossipov, A. Koshkin, N. Jakobsen, J. Skouv, H. Oerum, M. H. Jacobsen, J. Wengel, Proc. Natl. Acad. Sci. USA 2000 97, 5633-5638.

Received: ((will be filled in by the editorial staff))

Revised: ((will be filled in by the editorial staff)) Published online: ((will be filled in by the editorial staff)) 
Entry for the Table of Contents

\section{A twist to DNA structure}

Anna-Barbara Gerber, Christian J. Leumann * ........... Page - Page

Synthesis and properties of isobicyclo DNA

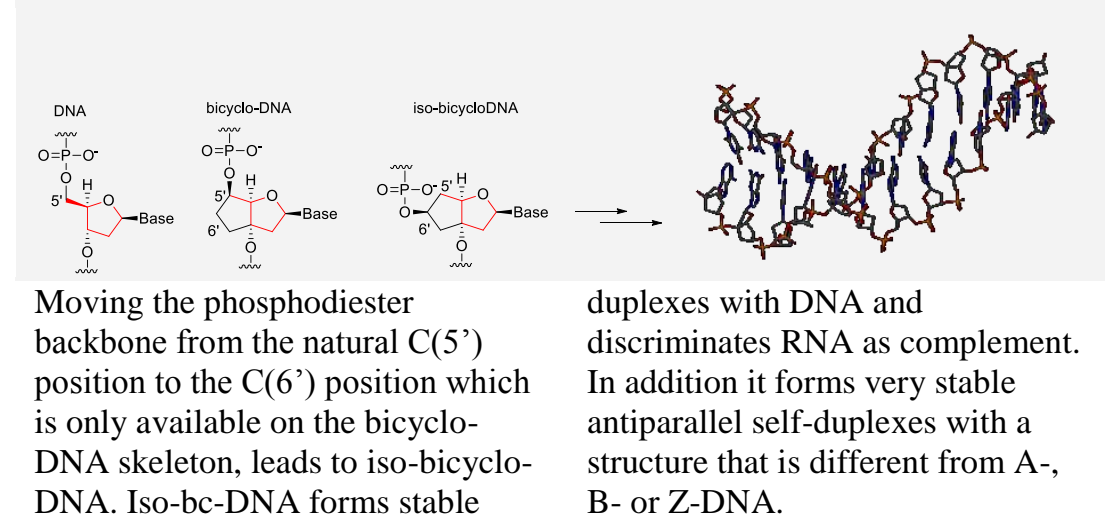

